\title{
Soil ecosystem services in different land use types in coastal Ecuador
}

\author{
Dissertation \\ Zur Erlangung des Doktorgrades \\ des Forstwissenschaftlichen Fachbereichs \\ der Georg-August-Universität Göttingen
}

\author{
Vorgelegt von \\ Ruth Magdalena López Ulloa \\ aus Ambato, Ecuador
}

Göttingen, May 2006 
D7

Referent: Prof. Dr. Edzo Veldkamp

Tag der mündlichen Prüfung:

Erschienen als elektronisches Dokument: 


\section{Preface}

Over the past decades there is an increasing pressure on natural and soil resources caused by an expanding human population. This has been the major motivation for me to get involved in environmental projects. It is my hope that the basic knowledge that I generated during this endeavour will help decision makers and planners to define the best strategies for maintaining natural ecosystems, help select conservation areas for the use of the future generations and maintain or implement environmentally friendly land use systems. This thesis is a contribution to understand how land use change affects soil processes and therefore soil environmental services. The research was part of a large project, "Evaluation of biological diversity of land-use systems in a mega-diverse region of Ecuador" financed by the German Federal Ministry of Education and Research and the University of Göttingen under the BioTEAM -Program, which I gratefully acknowledge.

I would like thank my promoter and supervisor Edzo Veldkamp, much of the thesis work and ideas in the research I owe to my supervisor. Despite the large distance, he was always willing to comment and discuss articles. Without his support, finishing this thesis would have hardly been possible. His knowledge, enthusiasm and his availability to revise my thesis were highly motivating. I am also very grateful to Free de Koning for his continuous support and ideas. Many thanks as well for the help of Jeroen Schoorl, who shared his knowledge and friendship in the most relevant stages of this thesis. A special thank to Roland Olscheswski and his family. Your warm-hearted hospitality, when I was in Germany is remembered with gratitude, and the work under Roland's lead in two challenging research project was a fruitful and nice experience.

Jackson Tyanakylis is acknowledging for his contributions to specific part of this thesis and for his friendship. Lorena Falconi López, my daughter, and Pool Segarra for assistance in GIS. Jesus Lino, Cesar Calderón and the vegetation group from Bio-Sys project are gratefully acknowledge for help in field assistance and vegetation data collection. Lcda. Betty Pico is acknowledged for her friendship, enthusiasm and logistic support for the BioSys Project. I am very thankful to many farmers with whom we had intensive contact during the fieldwork. I think I can learn a lot from the knowledge, modesty, hospitality and contentment of the people that live in the country side. My colleagues and friends Pablo 
Benitez, Dorthe Veddeler, Orlando Entralgo, Eleneide De Sotta, Vicente Guadalupe, Julia Arnold, Sonja Paul who always give emotional and logistic support, here in my country as in Germany. Finally, I thank my family: my husband Pablo my mother Elcira and my children Lorena, Anita and Diego for their moral support, love and comprehension.

Quito, May, 2006 


\section{Contents}

Preface $\quad 3$

Table of contents

$\begin{array}{ll}\text { Abstract } & 8\end{array}$

$\begin{array}{ll}\text { List of figures } & 9\end{array}$

List of tables $\quad 11$

$\begin{array}{ll}\text { Abbreviations and symbols } & 13\end{array}$

\section{Introduction}

$\begin{array}{ll}\text { 1.1 Soil environmental Services } & 15\end{array}$

$\begin{array}{ll}1.2 \text { Land use change } & 16\end{array}$

$\begin{array}{ll}1.3 \text { Outline of the thesis } & 17\end{array}$

2. Soil carbon stabilization in converted tropical pastures and forests depends on soil type

2.1 Introduction 19

$\begin{array}{ll}\text { 2.2 Material and Methods } & 21\end{array}$

2.2.1 Study area, site selection and sampling $\quad 21$

2.2.2 Laboratory analysis of soil samples $\quad 22$

$\begin{array}{ll}\text { 2.2.3 Statistical Analysis } & 24\end{array}$

2.3 Results 25

2.3.1 $\delta^{13} \mathrm{C}$ Signal following land use changes $\quad 25$

2.3.2 Soil $\mathrm{C}$ dynamic following land use changes $\quad 25$

2.3.3 Correlation between pasture - and forest - derived carbon and environmental factors 26

2.4 Discussion

2.4.1 The use of space-for-time substitution to reconstruct $\mathrm{C}$ dynamics in chronosequences

2.4.2 The use of $\delta^{13} \mathrm{C}$ signal as a tracer in forest to pasture to 5 secondary forest conversions $\quad 27$

2.4.3 Mechanisms of soil C stabilizations in pasture and forests 32

2.4.4 Soil C stocks and dynamics in a forest-to-pasture and pastureto-forest sequence 
3. Soil heterogeneity and topography influence plant diversity in a tropical mosaic landscape

3.1 Introduction 36

3.2 Material and Methods 38

$\begin{array}{ll}\text { 3.2.1 Study area } & 38\end{array}$

3.2.2 Site selection, field data collection and laboratory analysis $\quad 41$

3.2.3 Calculation and statistical analysis $\quad 42$

$\begin{array}{lll}3.3 \text { Results } & 43\end{array}$

3.3.1 Influence of land use and landscape position on soil characteristics and soil heterogeneity $\quad 43$

3.3.2 Herb diversity $\quad 45$

3.3.3 Correlations between herb diversity and soil characteristics $\quad 46$

3.4 Discussion

3.4.1 Herb diversity as affected by land use $\quad 49$

3.4.2 Herb diversity as affected by landscape position 52

3.4.3 Herb diversity in relation to soil properties and soil heterogeneity 52

3.4.4 Consequences for soil conservation measures $\quad 54$

4. The effect of erosion and sedimentation on soil organic carbon redistribution in a tropical landscape (Ecuador)

4.1 Introduction $\quad 56$

$\begin{array}{ll}\text { 4.2 Material and methods } & 57\end{array}$

$\begin{array}{ll}\text { 4.2.1 Study area } & 57\end{array}$

4.2.2 Site selection, soil sampling and measurement of carbon stock $\quad 60$

4.2.3 Modelling and statistical analysis $\quad 60$

$\begin{array}{ll}4.3 \text { Results } & 64\end{array}$ 
4.3.2 Impacts of erosion and sedimentation by land use change on SOC redistribution

4.4 Discussion

4.4.1 Soil $\mathrm{C}$ distribution related to environmental variables and land use

4.4.3 The impact of land use change on soil redistribution and the soil $\mathrm{C}$ budget 


\begin{abstract}
Soils provide ecosystem services which are natural functions of an ecosystem that can also be used for the benefits of humans. In recent years there is an increasing awareness that ecosystem services are important for human well being, however the ecosystem services that soils provide are not well quantified. In the present thesis some ecosystem services provided by soils are quantified in several study areas of coastal Ecuador. Furthermore the impact of different land uses on these ecosystem services is investigated. The different chapters of this thesis are the result of two different projects that focused on the implementation of payment for ecosystem services for soil $\mathrm{C}$ sequestration and biodiversity, which is illustrated by the contents of the different chapters: (1) stabilization mechanisms of soil carbon, which can help to predict the soil $\mathrm{C}$ sink function under different land use change scenarios; (2) the influence of soil and landscape characteristics on plant biodiversity; and (3) the effects of soil and land use on soil erosion and sedimentation and how this in turn affects soil $\mathrm{C}$ sequestration. The results show that soil $\mathrm{C}$ sequestration, biodiversity and soil conservation are important soil ecosystem services which strongly depend on land use and soil type. In future, quantitative information of the monetary value of these and other ecosystem services should form the basis for decision making processes involving conservation measures.
\end{abstract}

Keywords: soil ecosystem services, mechanism of $\mathrm{C}$ stabilization, carbon fixation, biodiversity, soil heterogeneity, soil $\mathrm{C}$ redistribution, erosion and sedimentation. 


\section{List of figures}

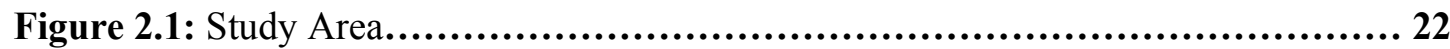

Figure 2.2: A: Plot of $\delta^{13} \mathrm{C}$ values of soil $\mathrm{C}$ in secondary forest soils against forest age, $\mathrm{B}$ : Plot of $\delta^{13}$ Cvalues in pasture soils against pasture age. C: Plot of $\delta{ }^{13} \mathrm{C}$ values of light fraction in forest soils against forest age; D: Plot of $\delta{ }^{13} \mathrm{C}$ values of light fraction in pasture soils against pasture age (circles correspond to Inceptisols and squares to Andisols). ........30

Figure 2.3: a: Stocks of Soil Carbon derived from pasture $(\mathrm{Cp})$, from forest $(\mathrm{Cf})$ and total carbon (T C) in 0-0.25m soil layer; a: On pastures Andisols, b: On pastures Inceptisols. c: On secondary forest Andisols. d: On secondary forest Inceptisol. Logarithmic curves to Cp, Cf and Total Carbon (T C).

Figure 3.1: Map of the study region showing distribution of sampling sites and reference towns. .40

Figure 3.2: Correlation of alpha and beta diversity with gamma diversity: in coffee agroforests (3.2a), pasture (3.2b) and rice (3.2c). The symbols correspond to alpha diversity in lowland, $\square$ alpha diversity in upland, $\boldsymbol{\Delta}$ beta diversity in lowland and $\circ$ beta diversity in upland. .50

Figure 3.3: Linear regression in rice crops between: magnesium exchangeable $(\mathrm{mg} / \mathrm{g})$ with clay percentage. $\mathrm{Mg}(\mathrm{mg} / \mathrm{g})=-20.45+2.25 *$ Clay $\left(\mathrm{R}^{2}=0.866\right)$. 
Figure 4.1: Location and DEM (Digital Elevation Model) of the research area in the Southwest of Ecuador, the small rectangle indicates the exact location of the study

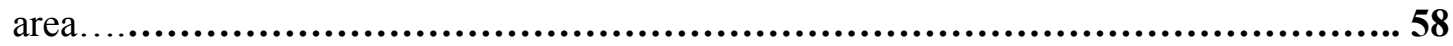

Figure 4.2: Soil Stratification..................................................62

Figure 4.3: Calculated spatial soil carbon distribution.................................68

Figure 4.4: Annual soil redistribution in the landscape for 5 different scenarios, showing: erosion (negative values) and sedimentation (positive values) . .........................69

Figure 4.5: Average soil C loss, gains and total balance by soil redistribution due to erosion and sedimentation processes on total and stratify study area......................71 


\section{List of Tables}

Table 2.1: Mean of soil $\delta^{13} \mathrm{C}$ values and soil carbon stocks $\left(\mathrm{Mg} \mathrm{C} \mathrm{ha}{ }^{-1}\right)$ in forest and pasture soils, at soil depth of $0-0.25 \mathrm{~m}$ in each soil type. ........................28

Table 2.2: Spearman rank correlation between carbon from pasture or from forest (Cdp, $\mathrm{Cdf}$ ) in $\mathrm{Mg} \mathrm{C} / \mathrm{ha}$ soil with soil characteristics and environmental variables (clay $(\%)$, sand (\%), silt (\%), (clay + silt) \%, $\mathrm{Al}_{\mathrm{o}}(\%), \mathrm{Fe}_{\mathrm{o}}(\%), \mathrm{Si}_{\mathrm{o}}(\%), \mathrm{Al}_{\mathrm{p}}(\%), \mathrm{Fe}_{\mathrm{p}}(\%)$, $\mathrm{C}_{\mathrm{p}}(\%) \mathrm{Al}_{\mathrm{p}} / \mathrm{Al}_{\mathrm{o}}, \mathrm{Al}_{\mathrm{o}}-\mathrm{Al}_{\mathrm{p}}(\%)$, elevation (masl), slope (degrees), precipitation (mm $\left.\mathrm{yr}^{-1}\right)$, above-ground biomass $\left(\mathrm{Mg} \mathrm{C} \mathrm{ha}^{-1}\right)$, soil $\mathrm{C} / \mathrm{N}$ ratio, pasture and forest age $(\mathrm{yr}))$, of pasture and forest soils at soil depth of $0-0.25 \mathrm{~m}$. .29

Table 3.1: Two Way-Analyses of Variance (ANOVA) of soil characteristics and soil heterogeneity $(\mathrm{CV})$. Fixed factors are land use and landscape position . .44

Table 3.2: Means and standard deviation (SD) of alpha, beta and gamma diversity, for three land use system and two landscape position in the Manabi area, (Two-way analysis of variance and Tukey-test).

Table 3.3: Pearson's rank correlation of plant diversity (relative beta, beta and gamma within plot) with soil characteristics and soil heterogeneity (CV). Only significant correlations are showed.

Table 3.4: General Linear Models of plant diversity and coefficient of variation of $\mathrm{pH}_{(\mathrm{H} 2 \mathrm{O})}, \mathrm{C}, \mathrm{P}, \mathrm{K}$, $\mathrm{Mg}$ and bulk density as continuous variables using stepwise variable selection, and land use and landscape position as fixed factors. LU1 = coffee; LU2 = pasture and LS1 = lowland soils.

Table 4.1: Soil $\mathrm{C}$ concentration and soil $\mathrm{C}$ content and environmental variables...........63

Table 4.2: Results of soil erosion and sedimentation from LAPSUS model under different land use change. Scenario: $0=$ baseline (actual land use system); $1=$ conversion 
from all coffee to pasture; $2=$ conversion from all coffee to rice; $3=$ conversion

from all rice to coffee; $4=$ conversion from all pasture to coffee. .................65

Appendix 2.1: General database for chapter $2 \ldots \ldots \ldots \ldots \ldots \ldots \ldots \ldots \ldots \ldots \ldots \ldots \ldots \ldots \ldots \ldots . \ldots 102$

Appendix 3. 1: List of herbs species in each land use system ..........................................106

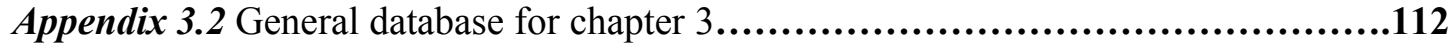

Appendix 4.1: Inputs variables to LAPSUS MODEL $\ldots . \ldots \ldots \ldots \ldots \ldots \ldots \ldots \ldots \ldots \ldots \ldots \ldots \ldots \ldots . . . . . .114$ 


\section{Abbreviations and symbols}

\begin{tabular}{|c|c|}
\hline $\mathrm{Al}_{\mathrm{o}}$ & aluminium extracted by acid-oxalate \\
\hline $\mathrm{Al}_{\mathrm{p}}$ & aluminium extracted by pyrophosphate \\
\hline$\alpha$ & alpha diversity \\
\hline$\alpha$ & relative alpha diversity \\
\hline ANOVA & analyses of variance \\
\hline $\mathrm{BD}$ & Bulk Density \\
\hline$\beta$ & beta diversity \\
\hline$\beta$, & relative beta diversity or species turnover \\
\hline Cdf & Carbon derived from forest \\
\hline Cdp & Carbon derived from pasture \\
\hline C Dif F-P $_{1}$ & difference between total $\mathrm{C}$ forest minus total $\mathrm{C}$ pasture \\
\hline $\mathrm{C}_{\text {gains }}$ & soil organic $\mathrm{C}$ gains by sedimentation \\
\hline $\mathrm{C}_{\text {loss }}$ & soil organic $\mathrm{C}$ losses by erosion \\
\hline $\mathrm{C}_{\mathrm{p}}$ & carbon extracted by pyrophosphate \\
\hline $\mathrm{C}_{\text {soil }}$ & mean soil organic $\mathrm{C}$ stock \\
\hline $\mathrm{CV}$ & coefficient of variation \\
\hline DEM & Digital Elevation Model \\
\hline df & degrees of freedom \\
\hline$\delta^{13} \mathrm{Cp}_{\mathrm{s}}$ & $\delta^{13} \mathrm{C}$ value of sample from pasture soil \\
\hline$\delta^{13} \mathrm{Cf}_{\mathrm{s}}$ & $\delta^{13} \mathrm{C}$ value of sample from forest reference soil \\
\hline$\delta^{13} \mathrm{Cp}_{1}$ & $\delta^{13} \mathrm{C}$ value of pasture residues \\
\hline$\delta^{13} \mathrm{Cf}_{1}$ & $\delta^{13} \mathrm{C}$ value of forest residues \\
\hline$\delta^{13} \mathrm{C}^{\mathrm{Dif}}{ }_{\mathrm{F}-\mathrm{P}}$ & difference between ${ }^{13} \mathrm{C}$ of forest minus ${ }^{13} \mathrm{C}$ of pasture \\
\hline $\mathrm{E}$ & East \\
\hline $\mathrm{F}$ & variance estimators \\
\hline $\mathrm{Fe}_{\mathrm{o}}$ & iron extracted by acid-oxalate \\
\hline $\mathrm{Fe}_{\mathrm{p}}$ & iron extracted by pyrophosphate \\
\hline GIS & Geographical Information System \\
\hline GLM & General Lineal Model \\
\hline GRM & General Regression Model \\
\hline
\end{tabular}




\begin{tabular}{ll} 
Gt & Giga tons \\
LAPSUS & LandscApe ProcesS modelling at mUlti dimensions and scaleS \\
LF & light fraction \\
LU1 & coffee \\
LU2 & pasture \\
LS1 & lowland soils \\
Max & maxim \\
Min & minima \\
N & North \\
p & p-value (level of significance) \\
S & South \\
Si & silica extracted by acid-oxalate \\
SD & Standard Desviation \\
SOC & Soil Organic Carbon \\
Tot_ero & mean soil erosion losses \\
Tot_out & mean erosion leaving the area \\
Tot_sed & mean soil sedimentation gains \\
Tot_SD & sediment delivery ratio \\
UTM & Universal Transversal Mercator \\
W & West \\
\hline
\end{tabular}




\section{Introduction}

Ecosystem services are natural functions of an ecosystem that can also be used for the benefits of humans (Costanza et al. 1997; Fearnside 1997a, Daily 1999). The term 'ecosystem services' was introduced to make apparent that the structure and function of ecosystems provide value (some of it measurable in money, some of it not) to humans (Daily et al. 1997). Ecosystem services are provided by biological, chemical and geological processes functioning at various scales (Kearns et al. 1998). The terms "ecosystem service" and "ecosystem function" are largely interchangeable, although ecosystem services can be defined as ecological processes that benefit people (Daily et al. 1997), whereas ecosystem functions can be considered all ecological processes regardless of whether they are beneficial to humanity or not.

\subsection{Soil ecosystem services}

Soils also provide ecosystem services. Soil functions can be categorized into four different types: habitat, regulation, production and information. Soils provide habitat for various plants and animals. They maintain biological and genetic diversity of organisms whose metabolism is the basis for the regulation and the production functions of soils. Regulation functions include the accumulation of energy and substances, as well as their transformation and transportation. Therefore the regulation functions maintain ecosystems and life support systems and include biogeochemical cycles and biotic-abiotic interactions that are important to all living organisms, and directly or indirectly benefit humans (Schneider et al. 1997). The production function consists of the processes that combine and change organic and inorganic substances, through primary or secondary production, into goods that can be directly used by humans (Binning et al. 2001). Information functions are aspects of soil ecosystems that contribute to human mental and spiritual well-being. 
According to Daily et al. (1997) the following main sub-functions and environmental services is provided by soil: (1) soil shelters seeds and provides physical support as they sprout and mature into adult plants. The cost of packing and storing seeds and of anchoring plant roots would be enormous without soil, besides soil helps to maintain biodiversity (Duque et al. 2002); (2) soil moderates the water cycle (water purification, recharging of groundwater water storage); (3) soil retains and delivers nutrients to plants; (4) soil plays a central role in the decomposition of dead organic matter and wastes; (5) soils are a key factor in regulating the Earth's major element cycles-those of carbon (air purificationregulation of climate), nitrogen (air and water purification), and sulphur.

These services all interact and depend on each other. Many relationships occur between the four function categories. The regulation and habitat functions often provide the basis for production and information functions (de Groot et al. 2002). There are also relationships among categories. For example, gas regulation affects the climate, and water regulation affects the water supply (de Groot et al. 2002). Not all ecosystems provide all services and some services are more prevalent in certain ecosystems. Though all four function categories will be present, many services will be site specific. An ecological characterization of soil ecosystem services is needed to inform decision-makers, prior to any attempt to value the services, of the ecological trade-offs associated with alternatives courses of action. For policy-making and planning, it is important to know what the important services provided by local ecosystems are.

\subsection{Land use change}

Virtually all of Earth's ecosystems have been significantly transformed through human activity. Changes have been especially rapid in the last 50 years and today the fastest changes are taking place in developing countries (World Resources Institute 2000). Among the many aspects of global change, land use change has been highlighted as a key humaninduced effect on ecosystems (Turner et al. 1998; Lambin et al. 2001). Land use change directly influences the provision of soil ecosystem services like e.g. production of food and timber, climate regulation, biodiversity and nutrient cycling (Daily et al. 1997). Presently soil degradation induced by human activities afflicts nearly $20 \%$ of the Earth's vegetated land surface (Oldeman et al. 1990) and threatens to disrupt soil ecosystems services in 
these areas. Unless human activities are carefully planned and managed, valuable soil asset will continue to be impaired or destroyed as soil takes hundreds to hundreds of thousands of years to build up (Jenny 1941).

Current agricultural expansion and intensification are putting extreme pressure on soil resources and consequently biodiversity. Agriculture and environmental sciences, therefore, need to develop tools for an ex ante evaluation of policies and regulations. This ex ante evaluation requires a basic understanding of natural processes. The general objective of the present thesis is to explore how soil ecosystem services change under different land use systems and which factors affect these soil ecosystem services. As soil ecosystem services are very diverse I focus on three questions: (1) how do soils affect $\mathrm{C}$ sequestration and how does this change under different land use systems? (2) How do soils affect biodiversity and how does this change under different land use systems? And (3) how do soil and land use affect soil erosion and deposition and how does this in turn affect soil $\mathrm{C}$ sequestration?

\subsection{Outline of the thesis}

The present thesis is a collection of papers that are submitted to different scientific journals and should be regarded as such. Many aspects related to ecosystem services are outside the scope of this thesis, although they are also influenced by soils and land use change.

Chapter 2 focuses on $\mathrm{C}$ sequestration in soils and more specifically on stabilization mechanisms of soil carbon. Whether soil $\mathrm{C}$ increase or decrease with afforestation or deforestation is determined by a number of factors, including previous land use (Paul et al. 2002), site preparation (Zinn et al. 2002), type of species planted (Paul et al. 2002; Guo and Gifford 2002), and soil type (Jackson et al. 2002, de Koning et al. 2003), including chemical and physical properties of soils that influence the level of resistance of soil organic carbon to degradation (Swift 2001). However few studies have looked into the influence of soil $\mathrm{C}$ stabilization mechanisms when factors affecting soil $\mathrm{C}$ are affected by land use changes. To gain further understanding of the dynamics of $\mathrm{C}$ pools after land use change, techniques are needed which can discriminate between soil $\mathrm{C}$ pools of different origin. Isotopes may provide a method that can do this. The most common isotope used to

study the dynamics of soil organic matter is ${ }^{13} \mathrm{C}$ because $\mathrm{C}$ is the most relevant indicator of 
state of soil organic matter and it represents about $50 \%$ of the mass of soil organic matter (van Noordwijk et al. 1997).

Chapter 3 discusses how soils affect plant diversity and more specifically how soil heterogeneity affects herb diversity. The main objective of this study was to test whether spatial variability at one level (soil) may propagate diversity at a higher level (plants). According to the concept of resource-based niches (McKane et al. 2002) diversity or heterogeneity of a limiting resource (soil nutrient) should provide a larger array of different niches, thereby reducing interspecific competition and promoting diversity in heterogeneous habitats (e.g., Kassen et al. 2000; Benton et al. 2003). Soil heterogeneity might be an important source of variation for genetic selection (Duque et al. 2002). Oliveira-Filho et al. (1994) demonstrated that the species density distribution was significantly correlated with some soil chemical characteristics and topographical features. Duivenvoorden and Lips, (1995) also found that tree species patterns were signicantly correlated with soil characteristics. In this chapter I examine whether the heterogeneity $(\mathrm{CV}$ of soil nutrients) of resources correlate with diversity of the plants. I examine such correlations in three different land use types that comprise a gradient of increasing anthropogenic modification (coffee agroforestry, pasture and rice) in Southwest Ecuador.

The fourth chapter deals mainly with an analysis of potential soil erosion and deposition under different land use systems. Many forest plantations and agroforestry systems are established under the assumption that they would provide services such as erosion control, $\mathrm{C}$ sequestration, soil fertility and water regulation. However, in reality very little is known regarding their effect on any soil ecosystem processes. A model that calculates potential erosion and deposition can be used to optimize the distribution of land use in the area to reduce soil loss and therefore nutrient depletion, and analyze alternative land use scenarios.

Finally, chapter 5 summarizes the main conclusions of the thesis, and gives some recommendations for future research. 


\section{2}

\section{Soil carbon stabilization in converted tropical pastures and forests depends on soil type}

\subsection{Introduction}

Globally, soils contain approximately $1500 \mathrm{Gt}$ soil organic carbon (soil C) in the upper meter of which about $44 \%$ is estimated to be located in soils in the tropics (Jobbagy and Jackson 2000). At the same time, soil C residence times decrease with increasing mean annual temperature and mean annual precipitation (Amundson 2001). As a result, the humid tropic is the area where the shortest residence times of soil $\mathrm{C}$ can be found. Because of the short residence times of soil $\mathrm{C}$, the soil $\mathrm{C}$ pool responds much more rapidly to environmental changes (like e.g. land use changes) in the tropics than in temperate areas. This is one of the reasons why deforestation is presently estimated to contribute about $23 \%$ to the human-induced $\mathrm{CO}_{2}$ emissions. While the majorities (about $75 \%$ ) of these emissions originate from the aboveground biomass, the remaining $25 \%$ is attributed to the decomposition of soil C (Detwiler 1986; Melillo et al. 1996).

Knowledge about mechanisms of soil $\mathrm{C}$ stabilization has improved considerably in the past decades. Mechanisms of soil C stabilization can be divided into three groups: recalcitrance, interactions and accessibility (Christensen 1996; Six et al. 2002). Recalcitrance refers to molecular level characteristics of organic substances that influence their degradation by microbes and enzymes. As microbes selectively degrade the less recalcitrant compounds, they gradually increase the average recalcitrance of the residual soil C (Oades 1988). Interaction comprises intermolecular interactions between organic and inorganic substances that alter the rate of degradation. Examples are sorption and complexation. Clays provide the vast majority of surface area for sorption of organic groups. Complexation of ions such 
as $\mathrm{Fe}^{3+}$ and $\mathrm{Al}^{3+}$ by organic substrates is a clear example of an interaction that increases stability. This is supported by the observation that soil $\mathrm{C}$ accumulates in very large amounts in soils that lack even amorphous alumino-silicate clays such as allophane (Mizota and Reeuwijk 1989). Accessibility comprises the location of organic substances as it influences their access by microbes and enzymes (Sollins et al. 1996). Aggregation can decrease accessibility of substrate to microbes.

This increased knowledge of soil $\mathrm{C}$ stabilization, however, has barely increased our ability to predict the direction and magnitude of changes in soil $\mathrm{C}$ stocks following land use changes in the tropics. This is mainly because soil $\mathrm{C}$ stabilization mechanisms are not considered to be critical when studying land use changes. In most cases the productivity of the different land uses is considered to be the key (e.g. Trumbore et al. 1995). As a result only a few of the known stabilizing mechanisms (recalcitrance and protection by clay) are explicitly considered in models that describe soil $\mathrm{C}$ dynamics. Therefore it is not very well known if and how quickly newly incorporated carbon is stabilized by one of the above mentioned processes.

In the present study, we wanted to highlight these problems by studying the soil $\mathrm{C}$ dynamics following land use changes in two soil groups in the pacific coastal plain of Ecuador with a contrasting genesis (Andisols and Inceptisols). We wanted to answer the following question:

- How much soil $\mathrm{C}$ remains stable after land use change and what are the responsible mechanisms of C-stabilization in Andisols and Inceptisols?

To answer these questions we compared a selection of pasture and secondary forest sites on Andisols and Inceptisols. We measured the soil C content, indicators of potential factors that stabilize soil $\mathrm{C}$ and we used the stable isotope signals $\left(\delta^{13} \mathrm{C}\right)$ to determine the size of labile and passive $\mathrm{C}$ pools (Balesdent et al. 1987). Although several studies have used $\delta^{13} \mathrm{C}$ in deforestation studies (e.g. Veldkamp 1994; Neill et al. 1996), few have analyzed the effects of secondary forest regrowth on sites formerly occupied by pastures. 


\subsection{Material and methods}

\subsubsection{Study area, site selection and sampling}

The study area is located in tropical North-western Ecuador, within the geographical coordinates of $80^{\circ} 05^{\prime} \mathrm{W}, 1^{\circ} 30^{\prime} \mathrm{N}$ and $78^{\circ} 40^{\prime} \mathrm{W}, 0^{\circ} 05^{\prime} \mathrm{S}$ (see Fig. 2.1). Elevation of the study sites varies between sea-level and 1600 m.a.s.l. Yearly annual precipitation varies from $1000 \mathrm{~mm}$ to just over $5000 \mathrm{~mm}$.

For the present study, we used a selection of 25 sites, which were part of a separate study to quantify the soil C sequestration potential of secondary forests (de Koning et al. 2003). The 'volcanic soils' used by de Koning et al. (2003) were identical to the 'Andisols' sites $(n=12)$ used in this study. The Andisols are relatively young soils developed on volcanic ashes with a mineralogy characterized by the presence of allophane. Generally they are acid or slightly acid, have high water retention, low bulk density, sandy or loamy texture, and a base saturation under $35 \mathrm{cmol}_{\mathcal{C}} / 100 \mathrm{~g}$. Andisol sites receive between 3000 and $5000 \mathrm{~mm}$ rain per year. As the 'sedimentary' soils used by de Koning et al. (2003) had quite a diverse soil genesis (and therefore probably different mechanisms of soil $\mathrm{C}$ stabilization), we excluded soils which were heavily weathered (Oxisols, Ultisols) and soils developed in recent alluvial and marine deposits (Entisols). The remaining sites $(n=13)$ can be characterized as being dominantly Inceptisols developed on sedimentary rocks (mainly siltstone) of Tertiary origin. These soils, which we call 'Inceptisols' in this study, are more developed than Andisols, with a loamy to clayey texture and they receive less than $2500 \mathrm{~mm}$ rainfall per year.

At each site a paired pasture plot and secondary forest or forest plantation plot were selected, plot size was at least 1 ha. Pastures and forests had different ages to allow for reconstruction of soil $\mathrm{C}$ changes over time. All secondary forests or plantation forests were established after abandonment or conversion of former pastures. These former pastures were established after cutting and or burning of the original forest. Also, all pastures in our sample were established after cutting and or burning of the original forest. Moreover, we selected two natural forests (one on an Inceptisol and one on an Andisol) used as reference forests. Prior to soil sampling, litter was collected of each plot for ${ }^{13} \mathrm{C}$ analysis. 


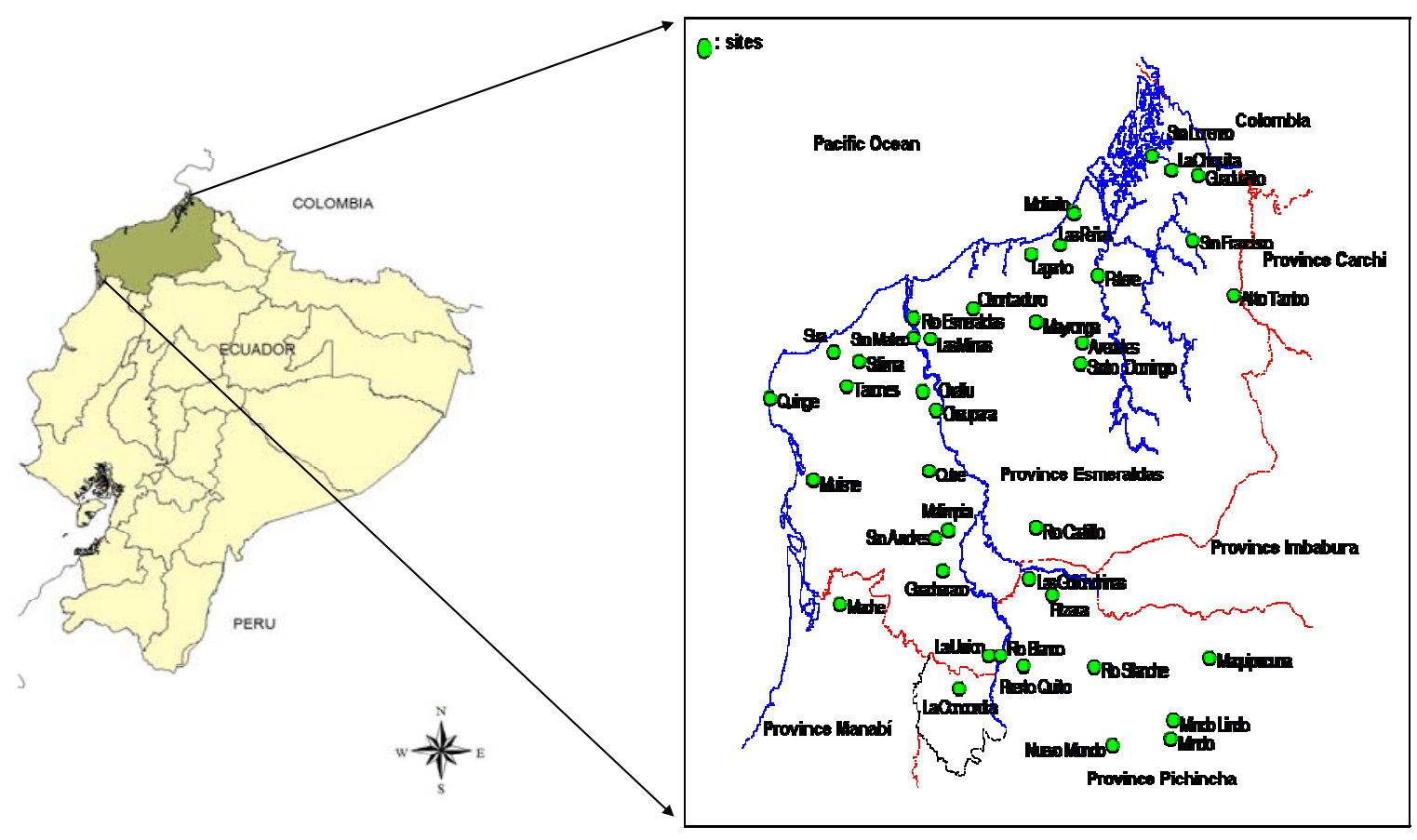

On each plot, 8 sampling points were selected within a $50 \times 50 \mathrm{~m}$ area using a stratified random sampling design (de Koning et al. 2003). At each sampling point, soil samples were taken with an auger at two fixed soil depths: $0-0.25 \mathrm{~m}$ and $0.25-0.5 \mathrm{~m}$. Soil samples were air-dried and then passed through a 2-mm sieve before laboratory analyses. At four sampling points, bulk density samples were taken and $\mathrm{pH}$ was measured for both depth intervals. Land use history, vegetation age and actual land management was obtained through interviews with landowners. In the forest plots, tree biomass was estimated by means of non-destructive inventories (López et al. 2002). Biomass was not measured in pasture plots. Annual precipitation was estimated using a digital interpolated precipitation map based on 20 weather stations in the study area.

\subsubsection{Laboratory analysis of soil samples}

Part of the individual samples was used to make composite samples for each layer per plot consisting of mixed material of the corresponding 8 samples. Carbon, nitrogen and carbon isotopes $\left({ }^{13} \mathrm{C}\right)$ were analyzed for all individual samples, and results are reported here as the 
mean value from 8 samples, while analysis of the other soil characteristics was done for the composite samples only. Carbon and nitrogen content was determined by means of dry combustion using an automated C \& N analyzer (Heraeus vario EL, Hanau, Germany). The light fraction (LF) organic matter was isolated by suspending the soil in a dense liquid and extracting the LF from the surface (Gregorich and Ellert 1993). Texture of composite samples was determined with the pipette method, distinguishing the three fractions clay (particle size $<0.002 \mathrm{~mm}$ ), loam (particle size between $0.002 \mathrm{~mm}$ and $0.063 \mathrm{~mm}$ ) and sand (particle size between $0.063 \mathrm{~mm}$ and $2 \mathrm{~mm}$ ). Mineralogy of composite samples was examined through acid-oxalate extractions of aluminium $\left(\mathrm{Al}_{\mathrm{o}}\right)$, iron $\left(\mathrm{Fe}_{\mathrm{o}}\right)$ and silica $\left(\mathrm{Si}_{\mathrm{o}}\right)$ and with pyrophosphate extractions of aluminium $\left(\mathrm{Al}_{\mathrm{p}}\right)$, iron $\left(\mathrm{Fe}_{\mathrm{p}}\right)$ and Carbon $\left(\mathrm{C}_{\mathrm{p}}\right)$, see for details de Koning et al. (2003). Oxalate extractions of Al, Fe and Si indicate all active components of $\mathrm{Al}, \mathrm{Fe}$ and $\mathrm{Si}$, dissolving non-crystalline minerals such as allophane, imogolite, amorphous and poorly crystalline oxides like ferrihydrite as well as organomineral Al- and Fe- humus complexes (Mizota and Van Reeuwijk 1989). Pyrophosphate extractions of $\mathrm{Al}, \mathrm{Fe}$ and $\mathrm{C}$ indicate all $\mathrm{Al}, \mathrm{Fe}$, and $\mathrm{C}$ present in organo-mineral humus complexes (Shoji 1993). The ratio of $\mathrm{Al}_{\mathrm{p}} / \mathrm{Al}_{\mathrm{o}}$ is indicative of the contents of allophane versus $\mathrm{Al}$-humus complexes in volcanic soils. $\mathrm{Al}_{\mathrm{p}} / \mathrm{Al}_{\mathrm{o}}$ values near 0 suggest that allophane is dominant while $\mathrm{Al}_{\mathrm{p}} / \mathrm{Al}_{\mathrm{o}}$ values near 1 indicate the predominance of Al-humus complexes (Mizota and van Reeuwijk 1989). Similarly, $\mathrm{Al}_{\mathrm{o}}$ minus $\mathrm{Al}_{\mathrm{p}}$ is an indication for noncrystalline minerals, with high values indicating high contents of these components. Oxalate extracted iron $\left(\mathrm{Fe}_{\mathrm{o}}\right)$ minus pyrophosphate extracted iron $\left(\mathrm{Fe}_{\mathrm{p}}\right)$ is an indication of the content of ferrihydrite.

Carbon isotope ratios were determined for soil $\mathrm{C}$, light fraction and litter samples. Tropical grasses are C4-type vegetation while forest trees are predominantly C3-type vegetation. The mechanism of photosynthetic $\mathrm{CO}_{2}$ uptake of $\mathrm{C} 3$ plants is more discriminating against ${ }^{13} \mathrm{C}$ than the $\mathrm{CO}_{2}$ uptake by $\mathrm{C} 4$ plants, resulting in a lower ${ }^{13} \mathrm{C} /{ }^{12} \mathrm{C}$ ratio in the $\mathrm{C} 3$ plants (Balesdent et al., 1988). In case of a conversion from C3-vegetation to C4-vegetation or vice versa the carbon isotope ratio of soil organic matter can be used to determine which fraction of the soil organic matter originates from either vegetation. The carbon isotope ratios are expresses as $\delta^{13} \mathrm{C} \%$ (Balesdent et al. 1988). The amounts of soil carbon derived from forest and pastures in the pasture plots (representing a conversion from C3-forest to C4-pasture) were calculated using a simple mixing equation (Balesdent and Mariotti 1996): 


$$
\begin{aligned}
& \mathrm{Cdp}=\left\{\left(\delta^{13} \mathrm{Cp}_{\mathrm{s}}-\delta^{13} \mathrm{Cf}_{\mathrm{s}}\right) /\left(\delta^{13} \mathrm{Cp}_{\mathrm{l}}-\delta^{13} \mathrm{Cf}\right)\right\}{ }^{*} \mathrm{Ct} \\
& \mathrm{Cdf}=\mathrm{Ct}-\mathrm{Cdp}
\end{aligned}
$$

where: $\delta^{13} \mathrm{Cp}_{\mathrm{s}}=\delta^{13} \mathrm{C}$ value of sample from pasture soil; $\delta^{13} \mathrm{C} f_{\mathrm{s}}=\delta^{13} \mathrm{C}$ value of sample from

forest reference soil; $\delta^{13} \mathrm{Cp}_{1}=\delta^{13} \mathrm{C}$ value of pasture residues; $\delta^{13} \mathrm{Cf}_{1}=\delta^{13} \mathrm{C}$ value of forest residues, $\mathrm{Cdp}=$ the amount of new carbon in the pasture sample; $\mathrm{Cdf}=$ amount of soil organic carbon from the forest. The advantage of this mixing equation compared to others is that it can be applied even if the isotope enrichments during $\mathrm{C}$ decay are high (Balesdent and Mariotti 1996). The amounts of soil carbon derived from forest and pastures in the secondary forest plots (representing a conversion from C4-pasture to $\mathrm{C} 3$-forest) were calculated in a similar way.

For the determination of the ${ }^{13} \mathrm{C}$ value, soil samples were ground to powder using a ball mill. The ${ }^{13} \mathrm{C}$ values were measured with an elemental C\&N analyzer (Fisons EA11081, Beverly, MA, USA) coupled with an isotope ratio mass spectrometer (Delta plus, Finigan MAT, Bremen, Germany). Forest and pasture litter samples were dried at $65^{\circ} \mathrm{C}$ to constant weight, finely ground for homogenisation, and analyzed in the same way. The average soil $\delta^{13} \mathrm{C}$ and bulk density of each plot for the $0-0.25 \mathrm{~m}$ layer and $\delta^{13} \mathrm{C}$ for pasture vegetation and forest vegetation were calculated and used for the calculation of fractions of carbon derived from pasture $(\mathrm{Cdp})$ and forest $(\mathrm{Cdf})$ in the pasture and forest plots. Average $\delta^{13} \mathrm{C}$ values measured for litter were $-14.18 \%$ for pastures and $-30.43 \%$ for forests.

\subsubsection{Statistical Analyses:}

We used Spearman rank correlation coefficients to explore the relationships among the contents of carbon derived from tropical pastures (Cdp), forest (Cdf) and the soil- and environmental variables. Analyses were done separately for Andisols and for Inceptisols as both soil groups have a different soil genesis. 


\subsection{Results}

\subsection{1 $\delta^{3}$ C signal following land use changes}

Average soil $\delta^{13} \mathrm{C}$ values in each plot show that in most sites soil $\mathrm{C}$ originated from a mixture of forest and pasture $\mathrm{C}$ (Table 2.1). Compared to the pasture soils, $\delta^{13} \mathrm{C}$ values in the $0-0.25 \mathrm{~m}$ layer of the forest soils were on average $2.9 \%$ lighter for Inceptisols and on average 2.0\% lighter for Andisols. On Inceptisols, forests contained on average $12.5 \mathrm{Mg} \mathrm{C}$ $\mathrm{ha}^{-1}$ more soil $\mathrm{C}$ than pastures. On Andisols, forests contained $8.0 \mathrm{Mg} \mathrm{C}^{-1}$ more soil $\mathrm{C}$ than pastures (Table 2.1). These results can be explained by the pasture age that on average is higher on Inceptisols (29 yrs) than on Andisols (17 yrs). The $\delta^{13} \mathrm{C}$ of the $0-0.25 \mathrm{~m}$. soil layer of each land use type was strongly related to age (Fig. 2.2 a, b), with highly significant correlation coefficients $(\mathrm{p} \leq 0.01)$ for both pastures on Andisols $\left(\mathrm{r}=0.85^{* *}\right)$ and on Inceptisols $\left(\mathrm{r}=-0.83^{* *}\right)$ and for forest on Andisols $\left(\mathrm{r}=0.58^{* *}\right)$, but not for forests on Inceptisols $(\mathrm{r}=0.17$ and $\mathrm{p}=0.44)$. For both soil types, $\delta^{13} \mathrm{C}$ values decreased with age in forest soils (Fig 2.2 a). However, in secondary forests $\geq 15$ years old on Andisols, values were more negative than in $\geq 15$ year old secondary forests on Inceptisols. In pasture soils, $\delta^{13} \mathrm{C}$ values increased with age, reflecting a gradual replacement of $\mathrm{C} 3$ carbon with $\mathrm{C} 4$ carbon (Fig. 2.2 b). In pasture soils, no clear differences between the two soil groups could be determined. Similar patterns with time could be observed in the $\delta^{13} \mathrm{C}$ signal of the light fraction (Fig $2.2 \mathrm{c}$ and $2.2 \mathrm{~d}$ ), but in general the $\delta^{13} \mathrm{C}$ values of the light fraction in forest soils and pasture soils were lower than the values of total soil C. Furthermore the variation in $\delta^{13} \mathrm{C}$ signal of the light fraction was larger than that of the soil $\mathrm{C}$.

\subsubsection{Soil C dynamics following land use changes}

We plotted the calculated soil C stocks ( $\mathrm{Cdp}, \mathrm{Cdf}$ and total C) against age of forest or pasture and used logarithmic curves to fit through the observed carbon stocks (Fig. 2.3). In Andisols, about $50 \mathrm{Mg} \mathrm{C} \mathrm{ha}^{-1}$ of the original forest remained in the soil after 30 years of pasture (Fig. 2.3a). In the same period, Cdp increased to about $20 \mathrm{Mg} \mathrm{C} \mathrm{ha}^{-1}$. Although we cannot reconstruct how much soil $\mathrm{C}$ was present in the original forest, total soil $\mathrm{C}$ stock clearly decreased with time. Part of the observed variation in total soil $\mathrm{C}$ was probably caused by the variation of the original amount of soil C. In Inceptisols (Fig. 2.3b), clearly 
less Cdf remained after 30 years of pasture (about $35 \mathrm{Mg} \mathrm{C} \mathrm{ha}^{-1}$ ). The increase in Cdp stocks was, however, more or less the same as in the Andisols (about $20 \mathrm{Mg} \mathrm{C} \mathrm{ha}^{-1}$ in 30 years, Fig. 2.3b). In the Inceptisols, total soil $\mathrm{C}$ stocks had a slight tendency to increase with time, but this increase was not significant and had a low $r^{2}(0.02)$, which was mainly caused by the slope that was very close to 0 .

In the secondary forest soils, changes in total soil $\mathrm{C}$ stocks, $\mathrm{Cdf}$ and $\mathrm{Cdp}$ were opposite to the changes observed in the pastures (Fig. 2.3 c, d). Curves start at forest age 7 as no younger forests were included in the sample. In the Andisols, the total soil $\mathrm{C}$ stock significantly increases with time $\left(r^{2}=0.42\right)$. This is caused by a strong increase in Cdf (which now consists of the carbon remainder from the original forest and the carbon from the new secondary forest, which was established after pasture abandonment). At the same time we observed a strong decrease in the amount of Cdp in Andisols. This resulted in virtually complete disappearance of Cdp on secondary forest sites older than 15 years (Fig, 2.3c). In the forests on Inceptisols, we observed no significant trend of total soil $\mathrm{C}$ or Cdf, although both had a weak tendency to increase with time. This lack of trend was caused by the large variation in observations combined with the slope that was close to zero. In contrast to Andisols, there was no decrease in Cdp with time (Fig. 2.3d). Most secondary forest sites $\geq 15$ years still had a Cdp stock of $10 \mathrm{Mg}$ or higher.

\subsubsection{Correlations between pasture- and forest-derived carbon and environmental factors}

To explain the direction and magnitude of the changes in Cdp and Cdf in pasture and secondary forest, we calculated the Spearman correlation coefficients of Cdp and Cdf $(\mathrm{Mg}$ $\mathrm{C} \mathrm{ha}^{-1}$ ) with the following soil characteristics and environmental variables: clay (\%), sand $(\%)$, silt (\%), clay+silt (\%), $\mathrm{Al}_{\mathrm{o}}(\%), \mathrm{Fe}_{\mathrm{o}}(\%), \mathrm{Si}_{\mathrm{o}}(\%), \mathrm{Al}_{\mathrm{p}}(\%), \mathrm{Fe}_{\mathrm{p}}(\%), \mathrm{Al}_{\mathrm{p}} / \mathrm{Al}_{\mathrm{o}}, \mathrm{Al}_{\mathrm{o}}-\mathrm{Al}_{\mathrm{p}}$ $(\%)$, elevation (m.a.s.l.), slope (degrees), precipitation $\left(\mathrm{mm} \mathrm{yr}^{-1}\right)$, soil $\mathrm{C} / \mathrm{N}$ ratio and aboveground biomass $\left(\mathrm{Mg} \mathrm{C} \mathrm{ha}{ }^{-1}\right)$. Correlations were calculated for Andisols and Inceptisols independently (Table 2.2). Cdp in Andisol pastures did not have significant correlations with any of the environmental variables or soil characteristics, although the correlations with pasture age and elevation were close to significant. As expected, Cdf in Andisol pastures significant decreased with pasture age, but Cdf also correlated with $\mathrm{Al}_{\mathrm{o}}, \mathrm{Si}_{\mathrm{o}}, \mathrm{Al}_{\mathrm{p}}$, the $\mathrm{Al}_{\mathrm{p}} / \mathrm{Al}_{\mathrm{o}}$ ratio and the difference $\mathrm{Al}_{\mathrm{o}}-\mathrm{Al}_{\mathrm{p}}$. In Inceptisol pastures, Cdp had a positive correlation with pasture age and a negative correlation with slope. Cdf did not have the 
correlations that were shown in the Andisols; instead the only positive correlation was with clay + silt content.

In secondary forest soils, variables that correlate with Cdp in Andisols were forest age, soil $\mathrm{C} / \mathrm{N}$ ratio and clay content, while Cdf was positively correlated with elevation, forest age, soil $\mathrm{C} / \mathrm{N}$ ratio and aboveground biomass (Table 2.2). In Inceptisol forest soils, Cdp was positively correlated with $\mathrm{Al}_{\mathrm{o}}$ and negatively with slope, while Cdf was positively correlated with clay, clay+silt, $\mathrm{Cp}$ and soil $\mathrm{C} / \mathrm{N}$ ratio.

\subsection{Discussion}

\subsubsection{The use of space-for-time substitution to reconstruct $C$ dynamics in chronosequences}

In the study by de Koning et al. (2003), from which we selected 25 sites, we showed that pasture and forest plots within sites were comparable and that differences measured were caused by land use and not by inherent site variability. However, the 'sedimentary soils' studied by de Koning et al. (2003) included a large variation of soils over all sites. By excluding sites which had a clearly different soil genesis (see methods) we are confident that within the two groups of soil studied, soil forming factors were relatively similar, following the recommendation by Powers and Veldkamp (2005). Furthermore, the number of sites within a soil group was relatively large $(n=12$ for Andisols and $n=13$ for Inceptisols), reducing the chance that trends observed in a chronosequence were based on outliers. We therefore think that within the two studied soil groups, sites with different times since forest or pasture conversion can be compared in a chronosequence. Information from this comparison should however be interpreted with care as part of the variation will be caused by variability which was not caused by the land use considered.

\subsubsection{The use of $\delta^{13} \mathrm{C}$ signals as a tracer in forest to pasture to secondary forest conversions.}

In studies of soil $\mathrm{C}$ dynamics following land use changes where $\mathrm{C} 3$ vegetation (like forest)

is replaced by $\mathrm{C} 4$ vegetation (like tropical grasses) and vice versa, $\delta^{13} \mathrm{C}$ can be used as a 
tracer to track back the origin of the soil C (e.g. Veldkamp 1994; Neill et al. 1996; Bashkin and Binkley 1998; Rhoades et al. 2000). However, several assumptions are made using

Table 2.1: Mean of soil $\delta^{13} \mathrm{C}$ values and soil carbon stocks $\left(\mathrm{Mg} \mathrm{C} \mathrm{ha}^{-1}\right)$ in forest and pasture soils, at soil depth of $0-0.25 \mathrm{~m}$ in each soil type.

\begin{tabular}{|c|c|c|c|c|c|c|c|c|}
\hline \multicolumn{9}{|c|}{ Inceptisols soils } \\
\hline \multirow{2}{*}{$\begin{array}{l}\text { Site } \\
\text { ID }\end{array}$} & \multicolumn{3}{|c|}{$\delta^{13} C_{(0-0.25 \mathrm{~m})}$} & \multicolumn{3}{|c|}{$\underline{C M g} \mathrm{C}$ ha-1 $(0-0.25 \mathrm{~m})$} & \multicolumn{2}{|c|}{$\underline{\text { Age (years) }}$} \\
\hline & Forest & Pasture & $\overline{\delta 13 C}$ Dif F-P $\S$ & Forest & Pasture & C Dif F-Pq & Forest & Pasture \\
\hline 12 & -23.29 & -21.45 & -1.84 & 68.9 & 60.8 & 8.1 & 10 & 25 \\
\hline 13 & -24.06 & -22.86 & -1.2 & 58.5 & 55.8 & 2.7 & 18 & 25 \\
\hline 16 & -24.68 & -22.64 & -2.04 & 63.4 & 58.8 & 4.6 & 15 & 35 \\
\hline 17 & -25.73 & -21.54 & -4.19 & 77.6 & 64.1 & 13.5 & 14 & 32 \\
\hline 22 & -24.54 & -22.68 & -1.86 & 55.3 & 37.3 & 17.9 & 10 & 30 \\
\hline 23 & -26.45 & -21.5 & -4.95 & 46.0 & 40.0 & 6.0 & 11 & 30 \\
\hline 25 & -25.44 & -18.47 & -6.97 & 100.0 & 62.6 & 37.4 & 15 & 45 \\
\hline 28 & -26.37 & -20.22 & -6.15 & 40.4 & 52.5 & -12.1 & 16 & 38 \\
\hline 29 & -25.45 & -24.82 & -0.63 & 64.3 & 47.7 & 16.7 & 15 & 20 \\
\hline 31 & -26.36 & -26.22 & -0.14 & 51.4 & 52.4 & -1.0 & 8 & 2 \\
\hline 32 & -26.19 & -24.83 & -1.36 & 80.1 & 53.6 & 26.5 & 10 & 30 \\
\hline 33 & -24.26 & -20.79 & -3.47 & 74.6 & 54.3 & 20.3 & 17 & 25 \\
\hline 35 & -25.84 & -22.56 & -3.29 & 79.3 & 57.7 & 21.5 & 20 & 35 \\
\hline Mean & -25.28 & -22.35 & -2.93 & 66.14 & 53.66 & 12.48 & 14 & 29 \\
\hline Máx† & -23.29 & -18.47 & -0.14 & 100.0 & 64.11 & 37.41 & 20 & 45 \\
\hline $\operatorname{Min} \ddagger$ & -26.45 & -26.22 & -6.97 & 40.36 & 37.34 & -12.14 & 8 & 2 \\
\hline \multicolumn{9}{|c|}{ Andisols soils } \\
\hline 4 & -27.00 & -23.69 & -3.30 & 98.5 & 61.7 & 36.8 & 20 & 20 \\
\hline 5 & -26.74 & -24.19 & -2.55 & 103.9 & 73.5 & 30.4 & 16 & 18 \\
\hline 7 & -26.76 & -25.05 & -1.71 & 82.8 & 89.0 & -6.2 & 21 & 13 \\
\hline 8 & -27.20 & -23.70 & -3.50 & 95.0 & 80.4 & 14.5 & 15 & 15 \\
\hline 9 & -26.38 & -24.70 & -1.68 & 116.2 & 90.3 & 26.0 & 15 & 3 \\
\hline 10 & -25.87 & -25.18 & -0.69 & 107.8 & 129.2 & -21.4 & 15 & 6 \\
\hline 11 & -26.94 & -24.18 & -2.76 & 93.5 & 80.5 & 13.1 & 17 & 20 \\
\hline 15 & -26.50 & -22.13 & -4.37 & 70.8 & 66.7 & 4.1 & 11 & 30 \\
\hline 20 & -23.77 & -23.41 & -0.35 & 73.2 & 70.4 & 2.8 & 10 & 16 \\
\hline 21 & -25.84 & -25.61 & -0.23 & 68.9 & 81.5 & -12.6 & 11 & 7 \\
\hline 36 & -22.14 & -20.78 & -1.37 & 52.4 & 55.7 & -3.3 & 7 & 30 \\
\hline 37 & -24.10 & -22.80 & -1.30 & 99.0 & 86.8 & 12.3 & 10 & 20 \\
\hline Mean & -25.77 & -23.79 & -1.98 & 88.50 & 80.47 & 8.03 & 14 & 17 \\
\hline Máx†. & -22.14 & -20.78 & -0.23 & 116.2 & 129.2 & 36.81 & 21 & 30 \\
\hline $\operatorname{Min} t$ & -27.20 & -25.61 & -4.37 & 52.38 & 55.71 & -21.40 & 7 & 3 \\
\hline
\end{tabular}


Table 2.2: Spearman rank correlation between carbon from pasture or from forest (Cdp, $\mathrm{Cdf}$ ) in $\mathrm{Mg} \mathrm{C} /$ ha soil with soil characteristics and environmental variables (clay $(\%)$, sand (\%), silt (\%), (clay + silt) \%, Al $(\%), \mathrm{Fe}_{\mathrm{o}}(\%), \mathrm{Si}_{\mathrm{o}}(\%), \mathrm{Al}_{\mathrm{p}}(\%), \mathrm{Fe}_{\mathrm{p}}(\%)$, $\mathrm{C}_{\mathrm{p}}(\%) \mathrm{Al}_{\mathrm{p}} / \mathrm{Al}_{\mathrm{o}}, \mathrm{Al}_{\mathrm{o}}-\mathrm{Al}_{\mathrm{p}}(\%)$, elevation (masl), slope (degrees), precipitation (mm $\left.\mathrm{yr}^{-1}\right)$, above-ground biomass $\left(\mathrm{Mg} \mathrm{C} \mathrm{ha}{ }^{-1}\right)$, soil $\mathrm{C} / \mathrm{N}$ ratio, pasture and forest age (yr)), of pasture and forest soils at soil depth of 0-0.25 m.

\begin{tabular}{|c|c|c|c|c|}
\hline & \multicolumn{2}{|c|}{ Andisols pasture soils (12) } & \multicolumn{2}{|c|}{ Inceptisols pasture soils (13) } \\
\hline & Cdp & Cdf & Cdp & Cdf \\
\hline Elevation & -0.531 & -0.238 & -0.259 & 0.336 \\
\hline Precipitation & -0.161 & -0.126 & -0.022 & -0.005 \\
\hline Pasture age & 0.497 & $-0.822 * *$ & $0.676^{*}$ & -0.234 \\
\hline Slope & -0.364 & -0.018 & $-0.612 *$ & -0.224 \\
\hline Clay & 0.074 & 0.312 & 0.352 & 0.437 \\
\hline Sand & -0.063 & -0.364 & 0.049 & $-0.643 *$ \\
\hline Silt & 0.042 & 0.469 & -0.429 & 0.264 \\
\hline Clay+silt & 0.301 & 0.350 & -0.049 & $0.643 *$ \\
\hline $\mathrm{Al}_{\mathrm{o}}$ & -0.133 & $0.748^{* *}$ & -0.016 & 0.407 \\
\hline $\mathrm{Fe}_{\mathrm{o}}$ & -0.364 & -0.189 & 0.082 & 0.088 \\
\hline $\mathrm{Si}_{\mathrm{o}}$ & -0.035 & $0.699 *$ & 0.231 & 0.000 \\
\hline $\mathrm{Al}_{\mathrm{p}}$ & -0.273 & $0.783 * *$ & 0.016 & 0.077 \\
\hline & 0.007 & 0.545 & 0.148 & -0.110 \\
\hline $\mathrm{Al}_{\mathrm{p}} / \mathrm{Al}_{\mathrm{o}}$ & 0.161 & $-0.692 *$ & 0.104 & -0.264 \\
\hline $\mathrm{Al}_{\mathrm{o}}-\mathrm{Al}_{\mathrm{p}}$ & -0.140 & $0.734 * *$ & -0.060 & 0.302 \\
\hline $\begin{array}{l}\mathrm{Al}_{\mathrm{O}} / \mathrm{Sl}_{\mathrm{O}} \\
\mathrm{C}\end{array}$ & -0.168 & 0.294 & -0.187 & 0.291 \\
\hline \multirow{4}{*}{$\mathrm{C} / \mathrm{N}$} & -0.315 & $0.741 * *$ & 0.549 & 0.390 \\
\hline & -0.409 & 0.345 & 0.544 & -0.214 \\
\hline & \multicolumn{2}{|c|}{ Andisols forest soils (12) } & \multicolumn{2}{|c|}{ Inceptisols forest soils (13) } \\
\hline & Cdp & Cdf & Cdp & Cdf \\
\hline Elevation & -0.434 & $0.713 * *$ & -0.440 & 0.110 \\
\hline Precipitation & -0.385 & -0.063 & -0.379 & 0.005 \\
\hline Forest Age & $-0.756^{* *}$ & $0.657^{*}$ & 0.156 & 0.139 \\
\hline Slope & -0.246 & 0.554 & $-0.592^{*}$ & 0.036 \\
\hline Clay & $0.680^{*}$ & -0.284 & 0.343 & $0.757 * *$ \\
\hline Sand & -0.476 & 0.399 & -0.368 & $-0.626^{*}$ \\
\hline Silt & 0.406 & -0.308 & 0.143 & 0.022 \\
\hline Clay+silt & 0.476 & $-0, .99$ & 0.368 & $0.626^{*}$ \\
\hline $\mathrm{Al}_{\mathrm{o}}$ & 0.245 & 0.140 & $0.632 *$ & 0.434 \\
\hline $\mathrm{Fe}_{\mathrm{o}}$ & -0.364 & 0.476 & -0.434 & -0.429 \\
\hline $\mathrm{Si}_{\mathrm{o}}$ & 0.322 & 0.161 & 0.544 & 0.247 \\
\hline $\mathrm{Al}_{\mathrm{p}}$ & 0.007 & 0.399 & 0.324 & 0.132 \\
\hline $\mathrm{Fe}_{\mathrm{p}}$ & 0.161 & 0.049 & 0.137 & -0.126 \\
\hline $\mathrm{Al}_{\mathrm{p}} / \mathrm{Al}_{\mathrm{o}}$ & -0.224 & -0.070 & 0.231 & 0.027 \\
\hline $\mathrm{Al}_{\mathrm{o}}-\mathrm{Al}_{\mathrm{p}}$ & 0.266 & 0.105 & -0.126 & 0.049 \\
\hline $\mathrm{Al}_{\mathrm{o}} / \mathrm{Si}_{\mathrm{o}}$ & -0.392 & 0.371 & -0.516 & -0.440 \\
\hline $\mathrm{C}_{\mathrm{p}}$ & -0.182 & $0.608 * *$ & 0.104 & $0.835 * *$ \\
\hline $\mathrm{C} / \mathrm{N}$ & $-0.748^{* *}$ & $0.804 * *$ & 0.434 & $0.593 *$ \\
\hline Biomass & -0.385 & $0.601 *$ & -0.011 & 0.302 \\
\hline
\end{tabular}

$*: \mathrm{p}<0.01$

$* *: p<0.05$ 
Figure 2.2, A: Plot of $\delta^{13} \mathrm{C}$ values of soil $\mathrm{C}$ in secondary forest soils against forest age, B: Plot of $\delta^{13} \mathrm{Cvalues}$ in pasture soils against pasture age. C: Plot of $\delta^{13} \mathrm{C}$ values of light fraction in forest soils against forest age; D: Plot of $\delta{ }^{13} \mathrm{C}$ values of light fraction in pasture soils against pasture age (circles correspond to Inceptisols and squares to Andisols).
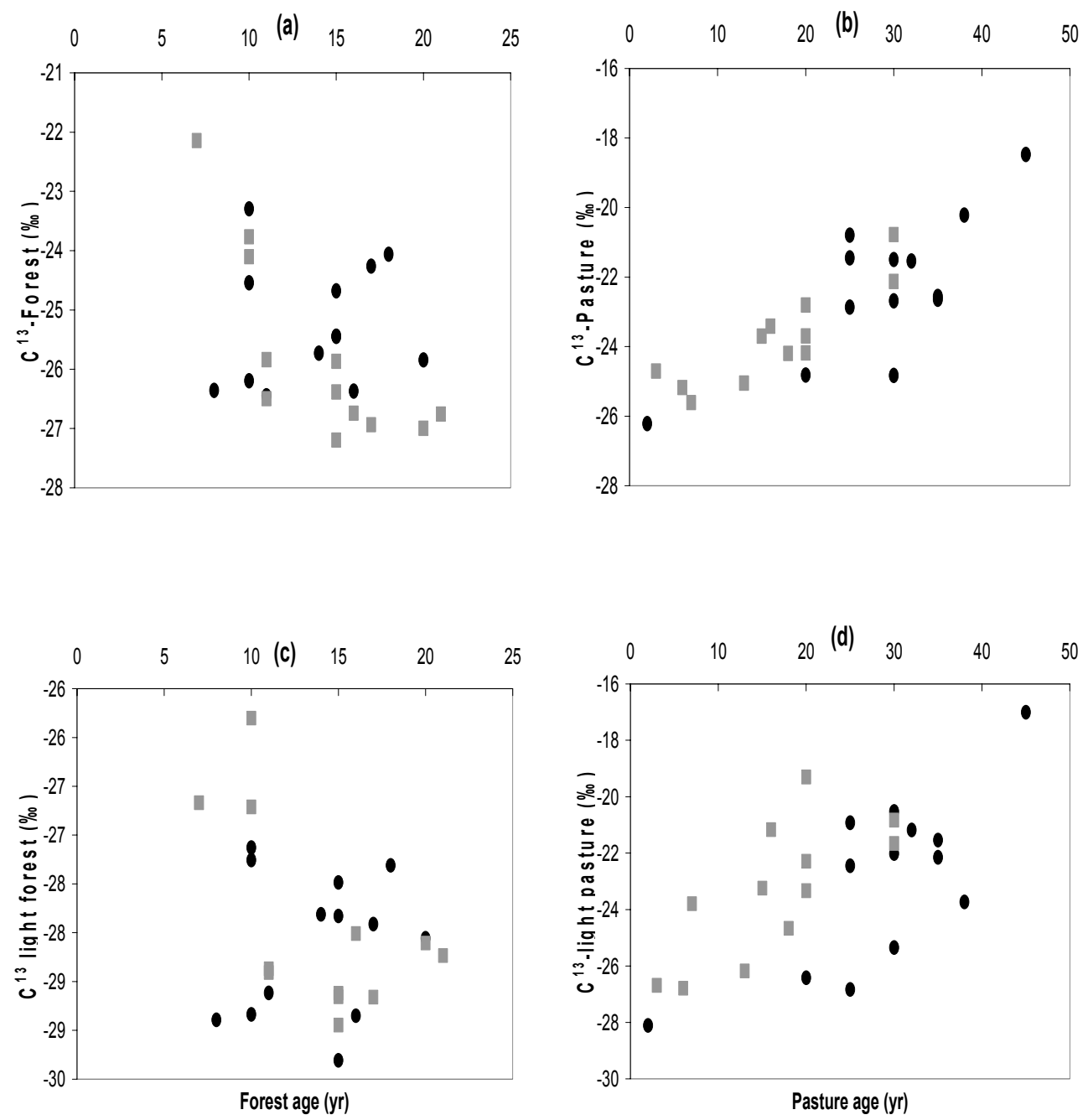
Figure 2.3: Stocks of soil carbon derived from pasture (Cp), from forest (Cf) and total carbon (T C) in 0-0.25m soil layer; a: On pastures Andisols. B: On pastures Inceptisols. C: On secondary forest Andisols. D: On secondary forest Inceptisol. Logarithmic curves to Cp, Cf and total carbon (T C).
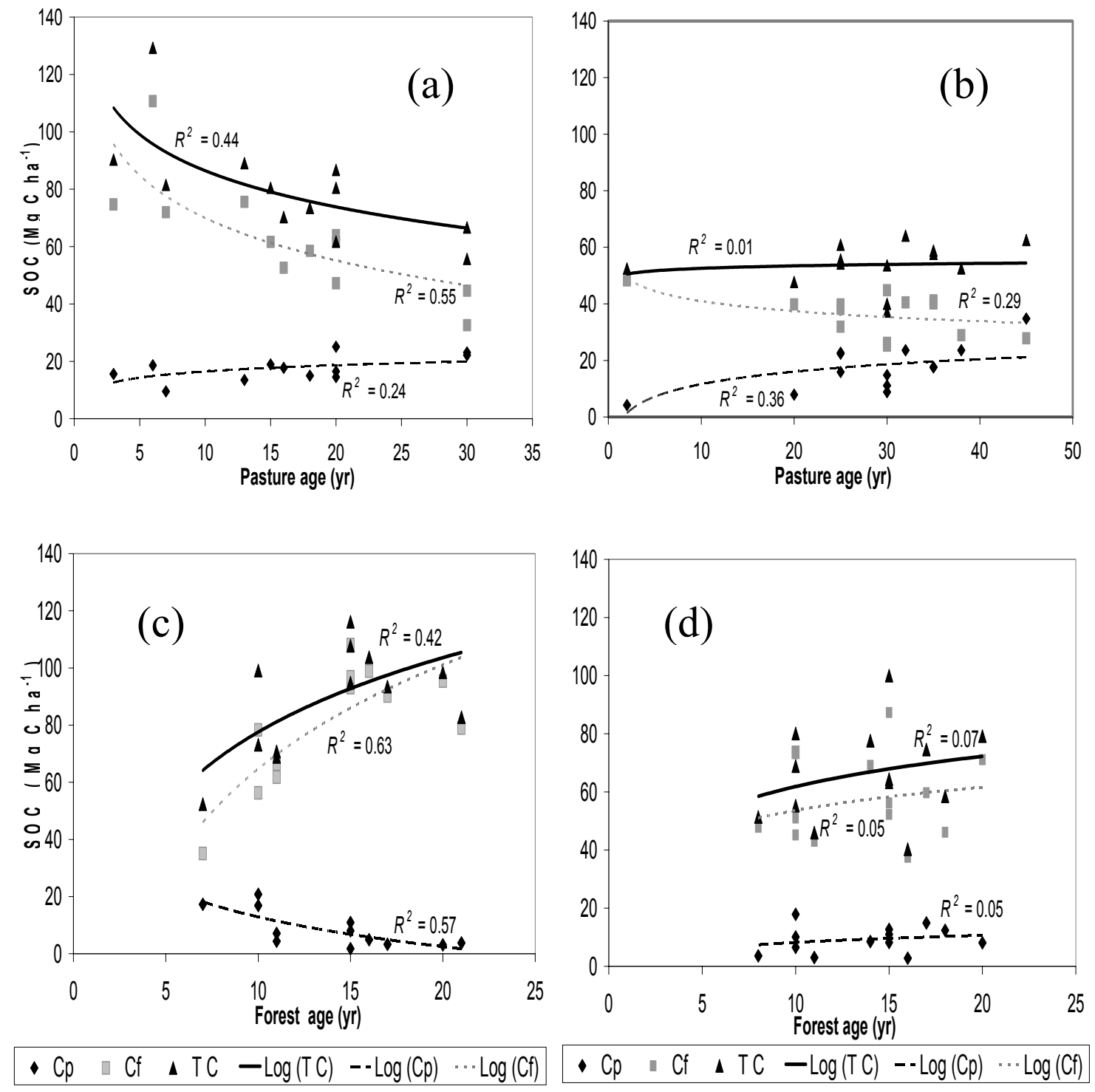

- Cp $\square$ Cf $\triangle$ TC $-\log (T C)--\log (C p) \cdots \log (C f)$

$\delta^{13} \mathrm{C}$, which may obstruct interpretation. Tropical pastures typically contain some C3 weeds, which contribution can be considerable (Trumbore et al. 1995). In a recent study in Costa Rica, Powers and Veldkamp (2005) concluded that this uncertain contribution of C3 prevented the use of $\delta^{13} \mathrm{C}$ as a precise tracer. However, they also showed that the 
assumption of constant (or pure) C4 input in the pastures led to more consistent results than using measured $\delta^{13} \mathrm{C}$ signals of randomly harvested pasture plants at the time of sampling. We therefore used the assumption that input of pastures was purely $\mathrm{C} 4$, while acknowledging that this led to an underestimation of pasture-derived carbon in the pasture and a corresponding overestimation of forest-derived carbon in the pastures.

In the present study we selected only one reference forest for each soil type and we did not select reference forest plots for each site, as these primary forests were not available. This means that we do not know how much soil $\mathrm{C}$ was present in the original forest (before clearing for pasture), nor do we know how much soil $\mathrm{C}$ was present in the pastures, before they were abandoned and a secondary forest grew back. This limits our possibilities to interpret the information from the $\delta^{13} \mathrm{C}$ analyses. In the pastures we cannot quantify how much C3 carbon has disappeared since forest clearing, but we can calculate which part of the carbon is still from the original forest in each soil type and which mechanisms of soil $\mathrm{C}$ stabilization are responsible. We can also see whether there are systematic changes with time of the total soil $\mathrm{C}$ stocks. In the secondary forests, we cannot distinguish between $\mathrm{C} 3$ carbon from the original forest and $\mathrm{C} 3$ carbon from the secondary forest. However, we can interpret $\mathrm{C} 4$ dynamics as this soil $\mathrm{C}$ can only originate from the pasture. Also here we can interpret systematic changes with time of the total soil C stocks.

\subsubsection{Mechanisms of soil C stabilization in pastures and forests}

What is stabilizing the soil $\mathrm{C}$ derived from forest in the Andisol pastures? Correlations of Cdf with $A l_{o}, \mathrm{Si}_{\mathrm{o}}, \mathrm{Al}_{\mathrm{p}}$, the $\mathrm{Al}_{\mathrm{p}} / \mathrm{Al}_{\mathrm{o}}$ ratio and the difference $\mathrm{Al}_{\mathrm{o}}-\mathrm{Al}_{\mathrm{p}}$ strongly suggest that in these soils, carbon is stabilized principally by Al-humus humus complexes $\left(\mathrm{r}=0.78^{* *}\right.$, Pearson correlation) and allophane (Shoji, 1993). For Andisols this has been demonstrated before in field studies (e.g. Veldkamp 1994; Torn et al. 1997; Powers 2001; Percival et al. 2000; Powers and Schlesinger 2002), where correlation analysis was used to show that complexation is an important mechanism of soil $\mathrm{C}$ stabilization in soils derived from volcanic ash. Also in laboratory experiments, Boudot (1992) showed that Al-humus complexes were more effective in reducing biodegradation of organic carbon than allophane. In Inceptisol pastures, forest derived carbon was correlated with clay and silt, suggesting that sorption of organic matter to clay minerals was the stabilizing mechanism. This soil stabilization mechanism has been also shown by e.g. Hassink (1997). Our results 
showed that the interaction mechanism of soil C stabilization play an important role in soil $\mathrm{C}$ permanence, but differ per soil type. They also show that in a period of 30 years, stabilization of soil $\mathrm{C}$ by Al-humus complexes in Andisols is larger than stabilization by clay minerals in Inceptisols (Fig. $2.3 \mathrm{a}, \mathrm{b}$ ).

As carbon derived from forest in the secondary forest soils is a mixture of 'old' soil C (from the original forest) and 'recent' soil C (from the secondary forest), correlations can be expected both with mechanisms that stabilize soil $\mathrm{C}$ and with indicators of forest productivity. Cdf in Andisols was significantly correlated with biomass, soil $\mathrm{C} / \mathrm{N}$ ratio and elevation, which are all related to forest productivity. In contrast in Inceptisols Cdf was correlated with clay content (which refers to the stabilization mechanism) and soil $\mathrm{C} / \mathrm{N}$ ratio (which is related to forest productivity). However because of the mixture of recent and stabilized Cdf in secondary forests, these correlations should be interpreted with care.

In secondary forests, correlations of Cdp with soil characteristics are more indicative, as we know that this carbon was incorporated relatively recently. Correlations can indicate whether this soil C is stabilized as well. In Andisols, Cdp correlated with clay content, but as the determination of clay in these soils is problematic (because of problems to disperse the clay, Mizota and van Reeuwijk 1989) we suspect that this is an artefact. In Inceptisols under secondary forest, $\mathrm{Cdp}$ was positively correlated with $\mathrm{Al}_{\mathrm{o}}$, and negatively correlated with slope. The negative correlation with slope is probably a reflection of erosion or other slope processes. The correlation with $\mathrm{Al}_{\mathrm{o}}$ (accompanied by a near-significant correlation with $\mathrm{Si}_{\mathrm{o}}$ ), may indicate the stabilizing process for Cdp in these soils. Acid oxalate extracts poorly crystalline and amorphous oxides. This suggests that these components may play a role in the stabilization of recently incorporated C.

With our approach we could show that interactions played a role in stabilization of soil C both in Andisols and in Inceptisols. However, as we did not measure any indicators of accessibility (e.g. aggregation stability or size) nor of recalcitrance (e.g. humus chemistry), it is not surprising that we did not find any evidence that these mechanisms were important in these soils. 


\subsubsection{Soil C stocks and dynamics in a forest-to-pasture and pasture-to-forest sequence}

Comparison of the deforestation and reforestation sequences of the two soil groups revealed quite contrasting soil $\mathrm{C}$ dynamics following land use changes. In Andisols, the total soil $\mathrm{C}$ stock sharply decreased following forest clearing and pasture establishment, while in Inceptisols this was not the case. Decreases in total soil organic carbon following pasture establishment in Andisols have been found in other studies (e.g. Veldkamp 1994; Rhoades et al. 2000), but also increases have been reported (e.g. Osher et al. 2003). As in our study the amount of soil $\mathrm{C}$ derived from pastures did not differ between the two soils (in both cases Cdp after 30 years of pasture was about $20 \mathrm{Mg} \mathrm{ha}^{-1}$ ), the difference in total soil $\mathrm{C}$ dynamics is caused by the larger amount of soil $\mathrm{C}$ which decomposed in the Andisols compared to the Inceptisols (Fig 2.3). However, this larger stock of decomposable soil $\mathrm{C}$ in Andisols is not the only reason why the total soil $\mathrm{C}$ stocks are higher. After thirty years of pasture the amount of soil $\mathrm{C}$ derived from the original forest is still a lot higher in the Andisols (about $50 \mathrm{Mg} \mathrm{ha}^{-1}$ ) than in the Inceptisols (about $35 \mathrm{Mg} \mathrm{ha}^{-1}$ ). The higher soil $\mathrm{C}$ stock in the Andisols, compared to the Inceptisols was caused by a combination of a larger stable soil $\mathrm{C}$ pool (stabilized by complexation with a turnover time of more than 30 years) and a larger decomposable soil $\mathrm{C}$ pool (turnover time less than 30 years). The larger stable soil $\mathrm{C}$ pool in Andisols combined with stronger correlations with the stabilizing mechanism (Table 2.2) suggests that the mechanism of $\mathrm{C}$ stabilization in Andisols was more effective than the mechanism of $\mathrm{C}$ stabilization in Inceptisols.

In the secondary forest soils, the opposite trends could be observed compared to the pastures. The increase in total soil $\mathrm{C}$ of Andisols can only be explained by the strong increase in forest derived $\mathrm{C}$ and, according to the correlations, this may be explained by a high leaf litter production (Brown and Lugo 1990) and/or high root biomass production (Berish and Ewel 1988). In the Andisols, pasture derived soil C practically disappeared after $>15$ years of secondary forest. This strongly suggests that the soil $\mathrm{C}$ that originated from the pasture was not stabilized in the Andisols. However, this result should be interpreted with care. While it was possible to get information about the age of the present land use, most owners could not provide information on how long pastures had existed before they were converted into secondary forests. We can therefore not exclude that in some of the sites the contribution of Cdp was already low at the time when the pasture was converted into a secondary forest. In the Inceptisols, total soil $\mathrm{C}$ and $\mathrm{Cdf}$ did not 
significantly increase (although there was a tendency to increase and the average soil $\mathrm{C}$ stocks under secondary forest were higher than the soil $\mathrm{C}$ stocks under pastures). The stronger increase in Andisols compared to Inceptisols may be caused by higher biomass production in Andisols which are located in an area with higher precipitation. In contrast to the Andisols, considerable amounts of Cdp were observed in Inceptisols under secondary forest of $\geq 15$ years. This suggests that soil $\mathrm{C}$ that was incorporated in the pastures was more stable in Inceptisols than in Andisols.

\subsection{Conclusion}

In this study we have shown that soil $\mathrm{C}$ stocks in Andisols and Inceptisols react differently on land use changes. This difference was probably caused by a combination of different factors: (1) Forest productivity, where litter input in the secondary forests on Andisols was probably higher than secondary forests on Inceptisols (López et al. 2002). (2) In Andisols more soil $\mathrm{C}$ was stabilized than in Inceptisols and the processes of stabilization were different. We found indications that relatively recently incorporated soil $\mathrm{C}$ was stabilized in Inceptisols through interactions with poorly crystalline $\mathrm{Al}$ (hydr-) oxides, while in Andisols this was not the case. In neither Inceptisols nor Andisols did we find indications that the processes that are responsible for the long-term ( $>30 \mathrm{yrs}$ ) stabilization of soil C played a role in the stabilization of recently incorporated soil $\mathrm{C}$. The reason may be that the soil $\mathrm{C}$ turnover in these stabilized pools is so slow that in the few decades that these land use changes had taken place no significant changes have occurred.

\section{Acknowledgements}

This study was financed by the Tropical Ecology Support Program (TOEB) of the German Technical Cooperation (GTZ) and the German Federal Ministry of Education and Research through the BIOTEAM program. We thank the TOEB staff - especially Elisabeth Mausolf for their continuous support. We acknowledge the many landowners who allowed us to collect field data and we thank Wolfgang Lutz of GTZ-Ecuador for his institutional support. 


\section{3}

\section{Soil heterogeneity and topography influence plant diversity in a tropical mosaic landscape}

\subsection{Introduction}

The global increase of land used and its intensity for agriculture have raised concerns about the loss of plant diversity in natural and agro-ecosystems, and the associated loss of potentially important ecosystem goods and services (Daily et al. 2000, Tilman et al. 2001, Robertson and Swinton 2005). In addition to habitat loss due to forest clearing for agriculture (Hughes et al. 1997), management practices leading to more homogenous conditions within agricultural land are generally believed to result in decreases of naturally occurring plants (Benton et al. 2003; Wijesinghe et al. 2005). Plant distribution within fields and over the landscape is affected by seed availability, inter and intra specific interactions of species and by the variation in nutrient availability, water availability, light intensity and temperature. These factors are in turn determined by land use system (e.g. agroforestry systems, annual crops or pasture), management practices (e.g. weeding, fertilizer application, and burning), and biophysical conditions, of which one would expect soils and their variability to play a major role due to their direct effect on water and nutrient availability.

Surprisingly, several previous studies in natural and anthropogenic ecosystems have found no or contradictory correlations between plant diversity and soil characteristics. Some studies have found an increase of species richness with increasing soil fertility (e.g. Gentry and Emmons 1987; Duivenvoorden 1994; Tuomisto et al. 1998), while others have found a decrease in plant diversity with increasing soil fertility (Huston 1980; Rosenzweig 1995) or no relationship at all (Clinebell et al. 1995; Föster et al. 2001). These contradictory results 
can possibly be explained by non-linear relationships between soil nutrients and plant diversity. For example, a 'hump'-shaped curve was found for soil phosphorus and soil $\mathrm{pH}$ with herb diversity in montane grasslands in Germany (Kahmen and Buchmann un published data report; Kahmen et al. 2005) while an hump -shaped curve was found for soil magnesium with dipterocarp tree species richness in natural rain forests in Sri Lanka (Ashton 1992). In such cases, the response of plant diversity to a specific nutrient could either be positive, negative or null, depending on the shape of the curve and the range of nutrient concentrations. However, instead of relating plant diversity directly to nutrient concentrations it may be more logical to relate spatial variability in soil properties in a certain area, for example a plot, to plant diversity. One would expect a positive correlation between plant diversity and soil heterogeneity, because heterogeneity of a limiting resource (e.g. soil nutrients) provides a larger array of different niches or patches, that allows a variety of plant species to colonize, to reduce interspecific competition and thus to promote plant diversity (Fitter 1982; Wilson 2000; Benton et al. 2003).

Soil heterogeneity in anthropogenic ecosystems results from a combination of natural heterogeneity and land management. Natural heterogeneity in soil characteristics is caused by variations in one or more soil forming factors (Jenny 1941), and factors such as topography and/or landscape position may affect plant diversity (e.g. Poulsen 1996). Characteristics such as slope and landscape position affect soil nutrient contents and redistribution, organic matter content, soil physical properties and drainage. In many tropical landscapes, abrupt discontinuities in edaphic conditions due to topographic position are common features (e.g. Clark et al. 1998). This usually translates into high habitat heterogeneity and corresponding species diversity (e.g. El-Ghani and Amer, 2003). Differences in water availability and drainage conditions between valley bottoms and hill crests have also been reported to affect the distribution of ground herbs in Ecuador (Poulsen and Balslev 1991) and could explain herb species specialization in Ecuadorian Amazonian rain forest (Tuomisto and Ruokolainen 1994).

Management related heterogeneity can also have multiple causes. Traditional farming systems with reduced fertilization, tillage, weed control, crop selection and rotation have been shown to have a higher ecological heterogeneity and related plant diversity (Albrecht 1995; Benton et al. 2003). Similarly, various studies comparing organic and conventional agriculture showed that herb diversity was higher in organic than conventional fields 
(Gabriel et al. 2006; Bengtsson and Ahnström 2005). Conventional tillage and monoculture cause the loss of stratified soil microhabitats and a concomitant reduction of plant diversity (Altieri 1999). In general, agro ecosystems with less intensive management systems (using fewer inputs and soil tillage) favour plant diversity (Stoate et al. 2001; Pysek and Leps 1991).

Land use systems with a strong tree component, such as forests or agroforestry systems, have a high standing biomass and a high spatial variability of litter input and quality within plots which in general increase both the contents and heterogeneity of soil properties such as carbon, nitrogen, $\mathrm{pH}$ and water availability (Gibson 1988; López-Ulloa et al. 2005). These parameters directly affect seed germination and plant establishment, and therefore plant diversity. In land use systems which are more homogeneous such as pastures and annual crops we expect less soil heterogeneity and thus lower species richness (Benton et al. 2003).

The goal of the present study was to determine how herb diversity was related to land use, soil heterogeneity and landscape position (lowland and upland soils). We test the following hypotheses:

- Herb diversity decreases with increasing land use intensity.

- Soil heterogeneity per se is a better predictor of herb diversity than specific concentrations of soil chemicals.

- Landscape position influences herb diversity.

We investigated a land use intensity gradient in a fragmented tropical landscape comparing (from low to high intensity) coffee agroforestry systems, pastures and rice fields. All land uses were located on both upland and valley bottom soils.

\subsection{Materials and Methods}

\subsubsection{Study Area}




\section{General study area description}

The study area is located in the coastal area of western Ecuador in the southern part of Manabí province (latitude $01^{\circ} 16^{\prime}-01^{\circ} 37^{\prime}$ South, longitude $80^{\circ} 22^{\prime}-80^{\circ} 28^{\prime}$ East) with an approximate surface of $500 \mathrm{~km}^{2}$ (see Figure 3.1). This area is situated within the Chocó biogeographical region, which is one of the world's hot-spots of biodiversity (Myers et al. 2000) and therefore is a priority area for the implementation of conservation measures. Mean annual temperature is $25^{\circ} \mathrm{C}$. Altitudes range from 80 to $500 \mathrm{~m}$ above sea-level. The mean annual precipitation (excluding El Niño years) varies from 800-1300 mm (INAMHI 2002), and the area has a distinct rainy season from January until May. The natural vegetation in the area is semi-deciduous forest (Sierra 1999).

\section{Soils and geomorphology}

Two physiographic units cover most of the area: river valleys with alluvial and colluvial deposits, situated south and southeast of the villages Pajan and Noboa and sloping areas including very steep slopes, mainly northwest of Pajan and Noboa (Schoorl et al. 2006). The geology and landscape genesis of the Noboa-Pajan region date back to the Oligocene. Parent material of the upland areas consist of sediments deposited by deep-sea currents or turbidites. Layers have different particle sizes ranging from fine clays to silts and fine sands, which are typical for turbidites (Kok and Michel, unpublished soil report- soil map, 2004). In the sloping areas dystric leptosols are formed with slopes ranging from 12 to $35^{\circ}$. Where active erosion takes place in the study area, leptosols can differ in texture and composition. Throughout this paper we will refer to the soils developed on these sloping areas as 'upland soils'. In the valleys, dystric and mollic fluvisols have developed on alluvial deposits. The valley soils in general have high clay content and drainage problems during the wet season. Throughout this paper we will refer to the soils developed in the valley as 'lowland soils'

\section{Land use systems}

The main land use systems in the study area are pasture (37\%), coffee $(22 \%)$, rice $(2 \%)$ and forest (22\%) (INEC-MAG-SICA 2001). For the present study, we selected three land use 
systems, considering the importance of crop area and grade of anthropogenic intervention: coffee agroforestry systems, pasture and rice. Agroforestry systems were established in the region 30 to 40 years ago by the replacement of the forest understory vegetation with coffee plants (mainly Coffea arabica L.) and planting of fruit trees and timber species with a multi-layered canopy structure. Pastures (consisting mainly of Panicum maximum Jacq.) have been established approximately 30 years ago, by sowing after slashing and burning of the original vegetation. In general, no fertilizer was applied to pastures. Rice (Oriza sativa L.) plots were also established after slashing and burning of original vegetation and or agroforestry system, but these plots have a rotation system $4-5$ years rice crops are follow by fallow by 2 or 3 years. In rice, urea fertilizer is occasionally applied. Following each harvest, cows often browse the stubble, and at the end of the dry season stubble residues are burnt in order to prepare the soil for sowing.

Figure 3.1: Map of the study region showing distribution of sampling sites and reference towns.

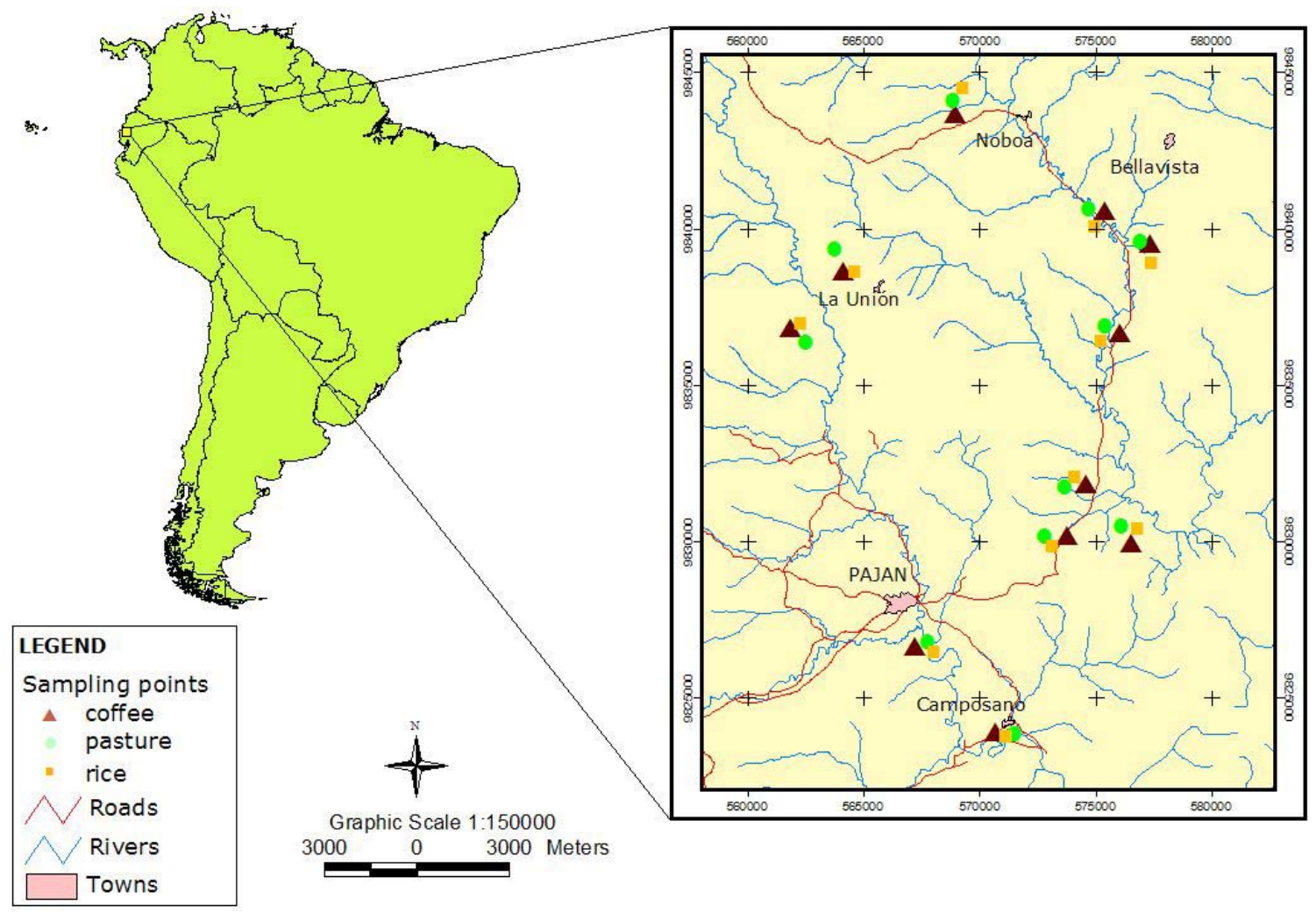




\subsubsection{Site selection, field data collection and laboratory analysis}

We selected twelve plots $\left(60 \mathrm{~m} \times 60 \mathrm{~m}=3600 \mathrm{~m}^{2}\right)$ of each of the three land use systems (36 plots in total, Figure 3.1). Plots were selected in such a way that the three land use systems formed a cluster (resulting in twelve clusters). Six clusters were located on alluvial fans and valley bottoms ('lowland soils'). The other six clusters were located on slopes ('upland soils'). With the exception of a higher exchangeable manganese contents in upland soils, chemical soil characteristics did not present significant differences. However, lowland soils are usually wetter than upland soils because the water table is higher, and because water originating from higher areas is redistributed to the valley floor.

In each plot, we took nine soil samples (depth of 0-0.25 m) from a 3 x 3 regular grid, each point $25 \mathrm{~m}$ apart). Soil samples were air-dried, passed through a $2 \mathrm{~mm}$ sieve, and stored in plastic bags for laboratory analysis. At each point soil $\mathrm{pH}$ was determined in the field in a slurry of $10 \mathrm{~g}$ soil and $25 \mathrm{ml}$ de-ionized water. Bulk density (BD) was determined by sampling an undisturbed soil sample using a $250 \mathrm{~cm}^{3}$ stainless steel cylinder. Bulk density samples were transported in plastic bags and dried in the laboratory at $105^{\circ} \mathrm{C}$ in paper bags for 24 hours and weighed. In the laboratory, air-dried soil samples were analyzed for total organic carbon and nitrogen using an automated C \& N analyzer (Heraeus Vario EL). Total phosphorus was determined after digestion under pressure with $\mathrm{HNO}_{3}$ following the method described by Heinrichs (1989). Exchangeable calcium (Ca), magnesium (Mg), manganese ( $\mathrm{Mn})$, iron (Fe) and aluminum (Al) were extracted by leaching soil samples with $100 \mathrm{ml}$ of unbuffered $1 \mathrm{M}$ ammonium chloride $\left(\mathrm{NH}_{4} \mathrm{Cl}\right)$ for $4-5$ hours. Cations in the extracts were quantified by atomic absorption spectroscopy (König and Fortmann 1996).

At the nine sampling points in the plots, herb diversity was sampled in $2.5 \times 2.5 \mathrm{~m}$ quadrants (total herbs plot area was $56.3 \mathrm{~m}^{2}$ by plot) during two sampling periods (April and October 2003). All herb individuals (including ferns) were gathered, and voucher specimens were identified to the lowest possible taxonomic level by experts at Guayaquil (GUAY) herbarium in Ecuador (Appendix 3.1). Total herb diversity (species richness) per plot was calculated by combining the results from the two sampling dates. 


\title{
3.2.3 Calculation and statistical analysis
}

\author{
Soil heterogeneity
}

Soil heterogeneity was defined as the coefficient of variation (CV) of each of the soil parameters analyzed $(\mathrm{pH}$, total carbon, total phosphorous, as well as $\mathrm{Na}, \mathrm{K}, \mathrm{Al}, \mathrm{Ca}, \mathrm{Mn}, \mathrm{Fe}$ and $\mathrm{Mg}$ exchangeable cations) over the nine sampling points within the plot. Coefficient of variation expresses standard deviation as a proportion of the mean, allowing comparisons independent of scale of measurement.

Species richness: additive partitioning

We partitioned the total observed herb plant species richness into diversity components for each plot, using the additive partitioning approach $\alpha+\beta=\gamma$ (Lande 1996). The sampling unit at the smallest scale (micro-scale) was represented by the quadrants within a plot. Alpha diversity (within-unit diversity) was calculated as the average number of species found in the nine quadrants in each plot. Gamma diversity corresponds to the total number of species in each plot while beta diversity was calculated by the difference between gamma and alpha diversity $(\beta=\gamma-\alpha)$. The relative alpha and beta diversity were obtained by dividing these values by gamma diversity and are expressed as $\alpha^{\prime}$ and $\beta$ '. Relative alpha and beta diversity were used in the analyses described below when comparing different land use systems, thereby controlling for the different total species richness at plot level (gamma diversity) in the studied land use systems.

\section{Effects of land use and landscape position}

The effects of land use and landscape position on plant diversity ( $\alpha, \beta$, and $\gamma$ ), soil characteristics and soil heterogeneity were tested by two-way analyses of variance (ANOVA) and post-hoc Tukey's pairwise comparisons 
Pearson's rank correlation was used as an explorative analysis to identify the edaphic and environmental factors that determine herb diversity. For a more detailed analysis of the influence of variability of soil chemical characteristics on relative beta, beta, and gamma diversity, we used a general linear model (GLM) with backward stepwise elimination (under the GRM module of Statistica 6.0, StatSoft, Inc. 2003). Land use and landscape position were used as categorical factors, when analyzing all plots, whereas for analyses of different land use systems independently, only landscape position was used as a categorical variable. The $\mathrm{CV}$ (heterogeneity) of $\mathrm{pH}_{\mathrm{H} 2 \mathrm{O}}$, total $\mathrm{C}$, total $\mathrm{P}$, bulk density $(\mathrm{BD})$ and $\mathrm{Na}, \mathrm{K}$, $\mathrm{Ca}, \mathrm{Mg}, \mathrm{Mn}$, and $\mathrm{Al}$ exchangeable cations were used as continuous predictors. In the model we included only the $\mathrm{CV}$ of soil parameters that were not significantly correlated with each other (only, the variable that presented the highest correlation was used in the model). We examined the explanatory power of significant effects using a Type III Likelihood Ratio test. Assumptions of normality and homogeneity of variance were tested in all variables prior to all statistical tests. We performed GRM, two way ANOVA analyses and correlations in Statistica 6.0.

\subsection{Results}

\subsubsection{Influence of land use and landscape position on soil characteristics and soil heterogeneity}

Contents of carbon $(\mathrm{C})$, total nitrogen $(\mathrm{N})$, potassium $(\mathrm{K})$ and exchangeable iron $(\mathrm{Fe})$ were higher in coffee than in rice (Table 3.1 - mean data from 9 points). Between landscape positions only Mn was significantly different (post-hoc Turkey's pairwise comparisons), with less exchangeable $\mathrm{Mn}$ in lowland soils.

Soil heterogeneity (expressed as CV of soil parameters) showed only significant differences between land-use systems for $\mathrm{pH}_{\mathrm{H} 2 \mathrm{O}}$ and between landscape positions for exchangeable $\mathrm{Fe}$. $\mathrm{pH}_{\mathrm{H} 2 \mathrm{O}}$ was more heterogeneous in coffee than in pasture and rice and exchangeable Fe was more heterogeneous in upland soils than in lowland soils (Table 3.1). 
Table 3.1: Two Way-Analyses of Variance (ANOVA) of soil characteristics and soil heterogeneity (CV). Fixed factors are land use and landscape position

\begin{tabular}{|c|c|c|c|c|c|c|c|c|c|c|c|c|}
\hline \multirow{2}{*}{$\begin{array}{l}\text { Factors } \\
\text { Land use }\end{array}$} & \multicolumn{12}{|c|}{ Soil Characteristics } \\
\hline & pH H2O & $C(\mathrm{mg} / \mathrm{g})$ & $N(\mathbf{m g} / \mathbf{g})$ & $P(\mathrm{mg} / \mathrm{g})$ & $\mathrm{Na}(\mathrm{mmol} / \mathrm{kg})$ & $\mathrm{K}(\mathrm{mmol} / \mathrm{kg})$ & $\mathrm{Ca}(\mathrm{mmol} / \mathrm{kg})$ & $\mathrm{Mg}(\mathrm{mmol} / \mathrm{kg})$ & Mn (mmol/kg) & $\mathrm{Fe}(\mathrm{mmol} / \mathrm{kg})$ & $\mathrm{Al}(\mathrm{mmol} / \mathrm{kg})$ & $B D(k g / m 3)$ \\
\hline Coffee & $6.0(0.6)$ & $26.7(5.6) \mathbf{a}$ & $2.6(0.5) a$ & $1.04(0.3)$ & $0.5(0.1) a$ & $18(10) a$ & $251(45)$ & $39(11) a$ & $0.9(0.3)$ & $0.05(0.03) \mathbf{a}$ & $0.6(0.8)$ & $1.1(0.1)$ \\
\hline Pasture & $6.2(0.2)$ & $24.4(6.9)$ ab & $2.3(0.6) a b$ & $0.98(0.4)$ & $0.8(0.4) a b$ & $13(7) a b$ & $217(58)$ & 50 (19) ab & $1.1(0.6)$ & $0.02(0.02) \mathbf{b}$ & $0.4(1.9)$ & $1.2(0.1)$ \\
\hline Rice & $6.5(0.5)$ & $21.0(3.4) \mathbf{b}$ & $2.0(0.3) \mathbf{b}$ & $0.94(0.4)$ & $1.4(1.2) \mathbf{b}$ & $10(4) \mathbf{b}$ & $245(53)$ & $62(28) b$ & $0.6(0.5)$ & $0.03(0.03) a b$ & $0.6(1.1)$ & $1.2(0.1)$ \\
\hline$F$ & 3.31 & 3.58 & 3.78 & 0.27 & 4.25 & 4.20 & 1.42 & 3.62 & 2.58 & 4.15 & 0.15 & 2.25 \\
\hline$P$ value & 0.066 & 0.049 & 0.031 & 0.758 & 0.023 & 0.024 & 0.257 & 0.038 & 0.091 & 0.026 & 0.860 & 0.113 \\
\hline \multicolumn{13}{|c|}{ Landscape } \\
\hline Lowland & $6.2(0.6)$ & $23.3(6.0)$ & $2.3(0.5)$ & $1.01(0.3)$ & $1.1(1.1)$ & $15(9)$ & $235(64)$ & $54(28)$ & $0.6(0.3) \mathbf{a}$ & $0.04(0.03)$ & $0.7(1.3)$ & $1.1(0.1)$ \\
\hline Upland & $6.3(0.3)$ & $24.8(5.8)$ & $2.3(0.5)$ & $0.95(0.4)$ & $0.6(0.4)$ & $13(7)$ & $240(40)$ & $43(14)$ & $1.1(0.5) \mathbf{b}$ & $0.03(0.03)$ & $0.3(0.3)$ & $1.2(0.1)$ \\
\hline$F$ & 0.69 & 0.62 & 0.02 & 0.34 & 3.42 & 0.58 & 0.07 & 1.05 & 11.2 & 0.66 & 1.53 & 0.37 \\
\hline \multirow[t]{2}{*}{$P$ value } & 0.464 & 0.446 & 0.800 & 0.548 & 0.073 & 0.451 & 0.796 & 0.313 & 0.002 & 0.405 & 0.224 & 0.565 \\
\hline & \multicolumn{12}{|c|}{ Soil Heterogeneity } \\
\hline Land use & pH H2O & CtCV & $\mathrm{Nt} \mathrm{CV}$ & PtCV & $\mathrm{NaCV}$ & KCV & $\mathrm{CaCV}$ & $\mathrm{MgCV}$ & $\mathrm{MnCv}$ & FECV & AICV & BDCV \\
\hline Coffee & $8.7(4) \mathrm{a}$ & $30.2(10)$ & $27.1(9)$ & $25.5(16)$ & $32.3(12)$ & $31.8(18)$ & $22.6(8)$ & $25.2(9)$ & $51.0(20)$ & $112(76)$ & $158(117)$ & $10.1(3)$ \\
\hline Pasture & $5.1(2) \mathbf{b}$ & $23.8(10)$ & $21.7(10)$ & $20.7(8)$ & $50.0(26)$ & $37.8(11)$ & $22.1(13)$ & $23.2(8)$ & $45.1(20)$ & $124(110)$ & $128(152)$ & $9.0(2)$ \\
\hline Rice & 5.5 (1) b & $26.5(9)$ & $22.6(9)$ & $20.5(11)$ & $43.8(16)$ & $33.1(8)$ & $20.6(10)$ & $23.8(11)$ & $52.5(20)$ & $99(83)$ & $154(99)$ & $8.0(3)$ \\
\hline$F$ & 6.34 & 1.37 & 1.22 & 0.67 & 2.72 & 0.68 & 0.12 & 0.14 & 0.46 & 0.11 & 0.21 & 1.58 \\
\hline$p$ value & 0.005 & 0.269 & 0.318 & 0.520 & 0.080 & 0.510 & 0.890 & 0.867 & 0.630 & 0.912 & 0.810 & 0.222 \\
\hline \multicolumn{13}{|c|}{ Landscape } \\
\hline Lowland & $6.0(2)$ & $23.9(8)$ & $21.7(7)$ & $18.7(9)$ & $38.7(21)$ & $35.4(15)$ & $20.8(10)$ & $22.9(10)$ & $50.6(22)$ & $84(67) \mathbf{a}$ & $134(138)$ & $8.5(2)$ \\
\hline Upland & $6.9(4)$ & 29.7 (11) & $25.9(11)$ & $25.8(13)$ & $45.4(18)$ & $33.1(11)$ & $22.6(11)$ & $25.2(9)$ & $48.5(18)$ & $139(98) \mathbf{b}$ & 159 (106) & $9.4(3)$ \\
\hline$F$ & 0.67 & 3.45 & 2.07 & 3.52 & 1.03 & 0.29 & 0.27 & 0.57 & 0.11 & 4.65 & 0.37 & 0.86 \\
\hline$p$ value & 0.418 & 0.072 & 0.167 & 0.069 & 0.317 & 0.597 & 0.609 & 0.454 & 0.745 & 0.035 & 0.548 & 0.360 \\
\hline
\end{tabular}

Means with the same letter were not significant different $(\alpha \approx 0.05)$ 


\subsubsection{Herb diversity}

A total of 24702 individuals and 270 species belonging to 65 families of vascular plants were recorded over all land use systems. The families that comprised the greatest percentage of the total number of species were Asteraeceae (16\%), Poaceae $(10 \%)$, Fabaceae (8\%) and Cyperaceae (6\%). In total, 98 herb species were found in coffee, 165 species in pasture and 174 species in rice.

Land use had a significant effect on relative alpha $(\mathrm{F}=4.26 ; \mathrm{df}=2 ; \mathrm{p}=0.024)$, relative beta $(\mathrm{F}=4.26 ; \mathrm{df}=2 ; \mathrm{p}=0.024)$ and gamma diversity $(\mathrm{F}=6.79 ; \mathrm{df}=2 ; \mathrm{p}=0.004)($ Table 3.2). The highest relative beta diversity was found in coffee (77\%) with slightly lower values in pasture $(75 \%)$ and rice $(72 \%)$. Average total species richness or gamma species diversity in plots was similar for pasture and rice, but significantly lower for coffee. Effects of landscape position on alpha and beta were not significant $(\mathrm{F}=0.13, \mathrm{df}=1, \mathrm{p}=0.640$ and $\mathrm{F}=$ $0.13, \mathrm{df}=1, \mathrm{p}=0.722$ respectively). However, differences in gamma diversity were significant $(\mathrm{F}=6.41, \mathrm{df}=1, \mathrm{p}=0.004)$, with lowland soils having significantly lower diversity than upland soils (Table 3.2).

Beta diversity was approximately three times higher than alpha diversity for all three land use systems, indicating that herb diversity in the study zone is mainly determined by microhabitat specialization or heterogeneity within plots (Figure 3.2). For coffee (Figure 3.2a), a clear separation between lowland and upland soils was observed, with higher diversity in upland soils. This separation was not observed for the other two land use systems (Figure 3.2b and 3.2c). Therefore, the effects of topography on total herb diversity or gamma diversity (Table 3.2) are mainly caused by herb distribution in coffee. 
Table 3.2: Means and standard deviation (SD) of alpha, beta and gamma diversity, for three land use system and two landscape position in the Manabi area, (Two-way analysis of variance and Tukey-test)

\begin{tabular}{|c|c|c|c|}
\hline Factors & $\begin{array}{l}\text { Relative Alpha Species diversity }\left(\alpha^{\prime}\right) \\
\qquad \text { Mean (SD) }\end{array}$ & $\begin{array}{l}\text { Relative Beta species diversity }\left(\beta^{\prime}\right) \\
\qquad \text { Mean (SD) }\end{array}$ & $\begin{array}{c}\text { Gamma Species Diversity }(\gamma) \\
\text { Mean (SD) }\end{array}$ \\
\hline Land use & $P=0.024$ & $P=0.024$ & $P=0.004$ \\
\hline Coffee-AFS (LU1) & $0.23(0.05) \mathbf{a}$ & $0.77(0.05) \mathbf{a}$ & $25.9(9.3) \mathbf{a}$ \\
\hline Pasture (LU2) & $0.25(0.05) a b$ & $0.75(0.05) a b$ & $39.6(12.1) \mathbf{b}$ \\
\hline Rice (LU3) & $0.28(0.04) \mathbf{b}$ & $0.72(0.04) \mathbf{b}$ & $38.6(11.5) \mathbf{b}$ \\
\hline Landscape position & $P=0.640$ & $P=0.648$ & $P=0.017$ \\
\hline Lowland soils (LS1) & $0.25(0.05)$ & $0.75(0.05)$ & $30.5(12.4) \mathbf{a}$ \\
\hline Upland soils (LS2) & $0.26(0.05)$ & $0.74(0.05)$ & $39.2(11.2) \mathbf{b}$ \\
\hline
\end{tabular}

\subsubsection{Correlations between herb diversity and soil characteristics}

Pearson correlations between relative beta, beta and gamma diversity and soil characteristics and soil heterogeneity showed variable tendencies (Table 3.3). For all land use types combined, a negative correlation was found between $\mathrm{Na}$ concentration and relative beta diversity ( $\left.\beta^{\prime}\right)$ and between total $\mathrm{C}$ and $\mathrm{N}$ and gamma diversity. For relative beta diversity positive correlations were found with total $\mathrm{C}$ and $\mathrm{N}$. Soil $\mathrm{pH}, \mathrm{BD}$, slope and elevation were positively correlated with gamma diversity. For individual land use types, most significant correlations with soil characteristics were found for rice, with positive correlations with BD and slope (for relative beta, beta and gamma diversity).

In contrast to the correlations with soil chemical concentrations, soil heterogeneity (CV) displayed only positive correlations with herb diversity (Table 3.3), confirming that $\mathrm{CV}$ seems to be a more consistent indicator of herb diversity. In contrast to soil chemical characteristics, most correlations were found in coffee: depending on diversity indicator, correlations were found with $\mathrm{CV}$ of total $\mathrm{P}$ and $\mathrm{CV}$ of exchangeable Mn. For all land use types combined and for rice separately, correlations were only found with $\mathrm{CV}$ of $\mathrm{Mg}$ and for pasture only with $\mathrm{CV}$ of $\mathrm{BD}$. No significant correlations were found with relative beta diversity ( $\left.\beta^{\prime}\right)$. 
Table 3.3: Pearson's rank correlation of plant diversity (relative beta, beta and gamma within plot) with soil characteristics and soil heterogeneity (CV). Only significant correlations are showed

\begin{tabular}{|c|c|c|c|c|c|c|c|c|c|c|c|}
\hline \multirow[b]{2}{*}{ Characteristics } & \multicolumn{2}{|c|}{$\frac{\text { All data ( } \mathbf{N}=\mathbf{3 6} \text { Data) }}{\text { Relative Beta Gamma }}$} & \multicolumn{3}{|c|}{ Coffee (N=12 Data) } & \multicolumn{3}{|c|}{ Pasture (N=12 Data) } & \multicolumn{3}{|c|}{ Rice (N=12 Data) } \\
\hline & $\begin{array}{l}\text { Relative B } \\
\text { Species } \\
\text { diversity }\end{array}$ & $\begin{array}{l}\text { a Gamma } \\
\text { species } \\
\text { diversity }\end{array}$ & $\begin{array}{l}\text { Relative Beta } \\
\text { Species } \\
\text { diversity }\end{array}$ & $\begin{array}{l}\text { Beta Species } \\
\text { diversity }\end{array}$ & $\begin{array}{l}\text { Gamma } \\
\text { species } \\
\text { diversity }\end{array}$ & $\begin{array}{l}\text { Relative Beta } \\
\text { Species } \\
\text { diversity }\end{array}$ & $\begin{array}{l}\text { Beta Species } \\
\text { Diversity }\end{array}$ & $\begin{array}{l}\text { Gamma } \\
\text { species } \\
\text { diversity }\end{array}$ & $\begin{array}{l}\text { Relative Beta } \\
\text { Species } \\
\text { diversity }\end{array}$ & $\begin{array}{l}\text { Beta Species } \\
\text { diversity }\end{array}$ & $\begin{array}{l}\text { Gamma } \\
\text { species } \\
\text { diversity }\end{array}$ \\
\hline $\mathrm{pH}(\mathrm{H} 2 \mathrm{O})$ & --- & $0.39^{*}$ & ---- & ---- & ---- & ---- & ---- & ---- & ---- & ---- & ---- \\
\hline $\mathrm{BD}(\mathrm{Kg} / \mathrm{m} 3)$ & --- & $0.54^{*}$ & ---- & ---- & ---- & ---- & --- & --- & $0.73^{\star *}$ & $0.74^{* *}$ & $0.76^{* *}$ \\
\hline$C(\mathrm{mg} / \mathrm{g})$ & $0.45^{*}$ & $-0.34^{*}$ & --- & --- & ---- & $0.62^{*}$ & --- & --- & --- & --- & ---- \\
\hline $\mathrm{N}(\mathrm{mg} / \mathrm{g})$ & $0.43^{*}$ & $-0.38^{*}$ & --- & ---- & ---- & $0.59^{*}$ & --- & $-0.60^{* *}$ & ---- & --- & --- \\
\hline $\mathrm{Na}(\mathrm{mmol} / \mathrm{kg})$ & $-0.46^{*}$ & ---- & --- & ---- & ---- & ---- & ---- & ---- & $-0.64^{*}$ & $-0.72^{* *}$ & $-0.71^{* *}$ \\
\hline $\mathrm{Mg}(\mathrm{mmol} / \mathrm{kg})$ & ---- & ---- & ---- & ---- & ---- & --- & ---- & ---- & $-0.58^{*}$ & $-0.83^{* *}$ & $-0.86^{\star \star}$ \\
\hline $\mathrm{Mn}(\mathrm{mmol} / \mathrm{kg})$ & --- & --- & --- & --- & --- & $0.67^{*}$ & --- & --- & --- & --- & ---- \\
\hline Sand (\%) & --- & --- & ---- & --- & --- & ---- & ---- & ---- & $0.64^{*}$ & --- & ---- \\
\hline Slope (grades) & --- & $0.53^{*}$ & ---- & --- & ---- & ---- & --- & ---- & $0.68^{*}$ & $0.66^{*}$ & $0.62^{*}$ \\
\hline \multirow[t]{2}{*}{ Elevation (m) } & ---- & $0.39^{*}$ & $-0.77^{\star *}$ & ---- & $0.58^{*}$ & ---- & $0.58^{*}$ & ---- & --- & ---- & ---- \\
\hline & \multicolumn{2}{|c|}{ All data ( $\mathrm{N}=36$ Data) } & \multicolumn{3}{|c|}{ Coffee (N=12 Data) } & \multicolumn{3}{|c|}{ Pasture ( $\mathrm{N}=12$ Data) } & \multicolumn{3}{|c|}{ Rice (N=12 Data) } \\
\hline $\begin{array}{l}\text { Soil } \\
\text { Heterogeneity }\end{array}$ & $\begin{array}{l}\text { Relative Be } \\
\text { Species } \\
\text { diversity }\end{array}$ & $\begin{array}{l}\text { a Gamma } \\
\text { species } \\
\text { diversity }\end{array}$ & $\begin{array}{l}\text { Relative Beta } \\
\text { Species } \\
\text { diversity }\end{array}$ & $\begin{array}{l}\text { Beta Species } \\
\text { diversity }\end{array}$ & $\begin{array}{l}\text { Gamma } \\
\text { species } \\
\text { diversity }\end{array}$ & $\begin{array}{l}\text { Relative Beta } \\
\text { Species } \\
\text { diversity }\end{array}$ & $\begin{array}{l}\text { Beta Species } \\
\text { diversity }\end{array}$ & $\begin{array}{l}\text { Gamma } \\
\text { species } \\
\text { diversity }\end{array}$ & $\begin{array}{l}\text { Relative Beta } \\
\text { Species } \\
\text { diversity }\end{array}$ & $\begin{array}{l}\text { Beta Species } \\
\text { diversity }\end{array}$ & $\begin{array}{l}\text { Gamma } \\
\text { species } \\
\text { diversity }\end{array}$ \\
\hline BD CV & ---- & ---- & ---- & ---- & ---- & ---- & $0.61^{*}$ & ---- & ---- & ---- & ---- \\
\hline Pt CV & ---- & --- & --- & $0.64^{*}$ & $0.61^{*}$ & --- & --- & ---- & --- & ---- & ---- \\
\hline $\mathrm{Mg} \mathrm{CV}$ & ---- & $0.34^{*}$ & ---- & --- & ---- & ---- & ---- & ---- & --- & ---- & $0.62^{*}$ \\
\hline $\mathrm{Fe} \mathrm{CV}$ & --- & --- & -- & --- & ---- & --- & --- & --- & --- & --- & --- \\
\hline $\mathrm{MnCV}$ & ---- & ---- & ---- & $0.64^{*}$ & $0.62^{*}$ & ---- & ---- & ---- & ---- & ---- & ---- \\
\hline
\end{tabular}

$*=$ significant $(\mathrm{P}<0.01)$ and $* *=$ high significant $(\mathrm{p}<0.001)$ 
Table 3.4: General Linear Models of plant diversity and coefficient of variation of $\mathrm{pH}_{(\mathrm{H} 2 \mathrm{O})}, \mathrm{C}, \mathrm{P}$, $\mathrm{K}, \mathrm{Mg}$ and bulk density as continuous variables using stepwise variable selection, and land use and landscape position as fixed factors. LU1 = coffee; LU2 = pasture and LS1 = lowland soils.

\begin{tabular}{|c|c|c|c|c|c|}
\hline & Models for all land uses combined (data $=36$ ) & $\boldsymbol{F}$ & $D f$ & $p$ & $\mathbf{R}^{2}$. \\
\hline \multicolumn{6}{|l|}{ Relative beta } \\
\hline Diversity & $\beta / Y=0.74+0.02 \mathrm{LU} 1+0.0036 \mathrm{LU} 2$ & 3.89 & 4 & 0.030 & 0.14 \\
\hline \multirow[t]{2}{*}{ Gamma Diversity } & $Y=23.5+0.47 \mathrm{Mg}$ CV -9.45 LU1+5.2LU2-3.8 LS1 & 7.83 & 4 & 0.000 & 0.44 \\
\hline & Models for coffee (data=12) & & & & \\
\hline Beta Diversity & $\beta=13.52+0.23 \mathrm{Mg}$ CV $-4.84 \mathrm{LS} 1$ & 20.17 & 2 & 0.000 & 0.78 \\
\hline \multirow[t]{2}{*}{ Gamma Diversity } & $Y=17.4+0.34 \mathrm{Mg} \mathrm{CV}-7.14 \mathrm{LS} 1$ & 23.92 & 2 & 0.002 & 0.81 \\
\hline & Models for pasture (data=12) & & & & \\
\hline Beta Diversity & $\beta=7.99+2.38$ Bulk Density CV & 5.90 & 2 & 0.035 & 0.31 \\
\hline \multirow[t]{2}{*}{ Gamma Diversity } & No Model & --- & --- & ---- & ---- \\
\hline & Models for rice (data=12) & & & & \\
\hline Beta Diversity & No Model & --- & --- & --- & --- \\
\hline Gamma Diversity & $Y=23.5+0.65 \mathrm{Mg} \mathrm{CV}$ & 6.26 & 2 & 0.031 & 0.32 \\
\hline
\end{tabular}

In the general lineal model with all land uses combined, only land use explained relative beta diversity, with neither landscape position nor soil variables included in the final model that explained $14 \%$ of relative beta diversity $(\mathrm{p}=0.030)$. In addition to land use and landscape position, heterogeneity of magnesium was included in the model for gamma diversity $(\mathrm{p}<0.001)$ for all land uses combined, with a coefficient of determination of $44 \%$ (Table 3.4).

For each land use type independently, the highest coefficients of variation were found for coffee, with significant models, explaining $78 \%$ and $81 \%$ of variation in beta and gamma diversity respectively. These models both included landscape position and $\mathrm{CV}$ of $\mathrm{Mg}$. For pasture, significant models were only found for beta diversity, with $\mathrm{CV}$ of bulk density as 
continuous variable explaining $31 \%$ of herb diversity. As for pasture, landscape position did not have a significant effect in rice. However, as for coffee, $\mathrm{CV}$ of $\mathrm{Mg}$ turned out to be an important variable, explaining $32 \%$ of gamma diversity (Table 3.4 ).

\subsection{Discussion}

Many different factors can influence plant diversity at a certain location and these factors will vary across locations and scales (Diamond 1988; Huston 1999). Without discarding the other factors that influence plant diversity and recognizing that a complex variable like plant diversity may not adequately described by linear correlations, we will primarily focus on effects of land use, landscape position, soil characteristics and soil heterogeneity.

\subsubsection{Herb diversity as affected by land use}

Our finding that land use strongly affects diversity of herbaceous plants has been shown several times in other studies. A land use effect on plant diversity is often related to management practices, such as soil tillage, density of plants and trees, use of chemicals, weeding, grazing and burning (e.g. Lawton et al. 1998; Albrecht 2003). Contrary to our first hypothesis, coffee agroforestry, which we classified as the least intensively managed land use system, had the lowest total herb diversity. Light intensity was probably a decisive factor in explaining the low herb diversity in agroforestry systems compared to pastures and agricultural crops. The importance of light intensity has been illustrated before by a study on abandoned pastures in which the number of herbaceous species decreased when available light was reduced, as a result of colonization by woody species (Aide et al., 1995). Light also plays a role in the hypothesis that increased nutrient availability reduces species richness, partly because greater productivity causes more shading (Tilman, 1988). Additionally, Wilson (1997) showed that herb species richness was significantly higher in prairie than forest, which he attributed to light intensity. Management intensity (is defined

for this research, as the alteration grade of natural vegetation; in this case from coffee to pasture and rice) did not play the overriding role that we expected at the start of the study. 
Figure 3.2: Correlation of alpha and beta diversity with gamma diversity: in coffee agroforests (3.2a), pasture (3.2b) and rice (3.2c). The symbols correspond to alpha diversity in lowland, $\square$ alpha diversity in upland, $\boldsymbol{\Delta}$ beta diversity in lowland and $\circ$ beta diversity in upland.
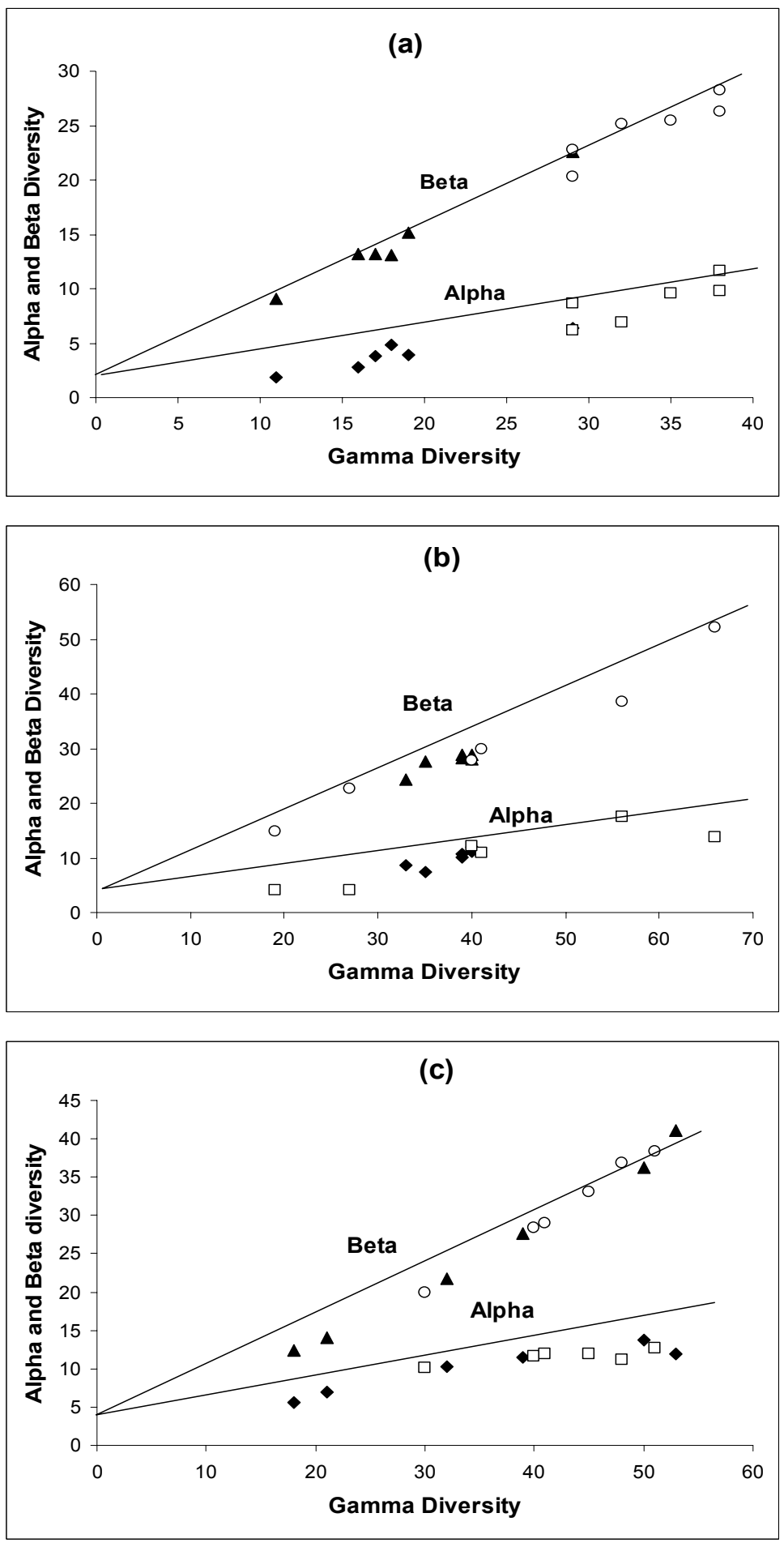
Figure 3.3: Linear regression in rice crops between: magnesium exchangeable $(\mathrm{mg} / \mathrm{g})$ with clay percentage. $\mathrm{Mg}(\mathrm{mg} / \mathrm{g})=-20.45+2.25 *$ Clay $\left(\mathrm{R}^{2}=0.866\right)$.

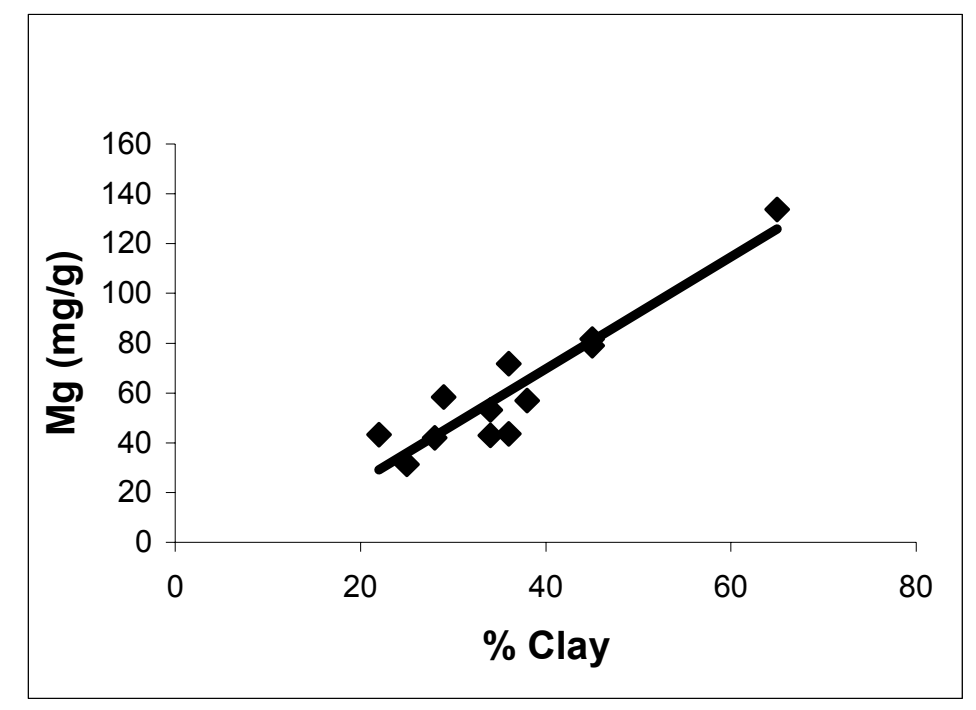

Management practices in rice and pasture in this tropical agricultural landscape are less intensive than in most conventional agriculture in temperate areas. In all three land uses systems, the use of agrochemicals is absent or very limited and all three land use systems are therefore comparable to organic farming systems, which have been demonstrated to maintain higher plant diversity than conventional agricultural systems in which agrochemicals are used on a regular basis (van Elsen 2000; Hole et al. 2005; Gabriel et al. 2006). Finally, the high landscape heterogeneity caused by the fine-scale mosaic of agricultural fields, agroforestry systems and secondary forests, favour seed dispersal between land use systems, so we do not expect that seed dispersal was limiting for herb diversity in any of the land use systems (Wilson 1992; Kneitel and Miller 2003).

In contrast to overall herb diversity, our results show that coffee agroforestry was the land use that had he highest relative species turnover ( $\left.\beta^{\prime}\right)$ demonstrating the importance of habitat heterogeneity in coffee plantations for plant diversity. This supports results of an additional study in the same area which demonstrated the importance of coffee agroforestry for the diversity and dispersal of tree species (Lozada et al, unpublished data). Moreover, this high relative within-site turnover in species is consistent with studies of insects in the same sites, and implies that a larger area of coffee agroforests is required to incorporate all 
the microhabitat heterogeneity, and adequately conserve its associated biodiversity (Tylianakis et al. 2005).

\subsubsection{Herb diversity as affected by landscape position}

The higher gamma diversity in coffee on upland soils compared to lowland soils may be related to farmers' preferences to select areas with less steep slopes for pastures and rice compared to coffee agroforestry. On upland soils, coffee is grown on steeper slopes (mean $16^{\circ}$, min $8^{\circ}$ and max slope $30^{\circ}$ ) than pastures (mean $13^{\circ}$, min $5^{\circ}$ and max slope $25^{\circ}$ ) and rice (mean $10^{\circ}$, min $5^{\circ}$ and max slope $15^{\circ}$ ). The contrast in slope and related drainage conditions between upland and lowland soils is therefore weaker for pasture and rice than for coffee. Moreover, severe compaction of pastures (as shown by bulk density) and erosion of rice fields (Schoorl et al. 2006) may have had such a strong influence on plant diversity that any relationship of plant diversity with topographic position in these land uses was masked. Meanwhile, in coffee agroforestry systems the lack of compaction and erosion may have preserved some of the original soil conditions and heterogeneity which still shows up in the relation with plant diversity. As was the case in our coffee agroforestry systems, the distribution of palms was also affected by landscape position (valley versus hill crests) in a Central Amazonian forest, which was attributed to differences in soil moisture and drainage conditions (Kahn and Castro 1995). Similar results were reported for understory herbs in an Ecuadorian rain forest (Poulsen and Balslev 1991).

\subsubsection{Herb diversity in relation to soil properties and soil heterogeneity}

The wide variety of soil properties that displayed either positive or negative correlations with herb diversity (Table 3.3) show that also in this study there was no clear 'best' soil property predictor for herb diversity. Although there have been many trials to look for a 'best' soil property to predict vegetation composition, the search for one all-explaining soil property for plant diversity is probably elusive (e.g. Gentry 1988). The combination of positive and negative correlations of soil parameters with herb diversity make it hard to interpret which of the soil parameters actually caused differences in herb diversity, because many of the parameters that correlate with herb diversity are also correlated among each other. Furthermore it is possible that there were non-linear relationships between soil characteristics and plant diversity as have been occasionally reported (e.g. Ashton 1992). 
In contrast to the combination of positive and negative correlations of soil chemicals with herb diversity, soil heterogeneity displayed only positive correlations with plant diversity. These positive correlations are to be expected because soil heterogeneity provides a more varied niche base, allowing occupation by a greater variety of herb species. Effects of soil heterogeneity on plant diversity have been shown in other studies in the tropics (Tuomisto et al. 2003; Tuomisto and Ruokolainen, 2002), however in these studies soil heterogeneity was considered over relatively large areas and related to variation in soil types (as we did with landscape position). Conversely, we analyzed the effect of heterogeneity in soil chemistry within 0.25 ha plots i.e. heterogeneity within one soil type. Although we found significant correlations between herb diversity and the CV of only a few soil chemicals, (with the CV of magnesium also showing up in the GLM models, Table 3.4) our interpretation is that soil variability in general rather than actual concentrations of $\mathrm{Mg}$ drove the diversity pattern. Magnesium variability was correlated with the variability of other soil nutrients (e.g., exchangeable $\mathrm{Ca}$ and other base cations) and magnesium correlates with clay content in these soils which are dominated by smectite clay minerals (see Fig. 3.3). Therefore, rather than suggesting an importance of $\mathrm{Mg}$ variability per se, $\mathrm{Mg}$ most likely indicated general variability in the soil structure and chemistry, and this variability provided a larger array of different niches or patches, which is expected to promote plant diversity.

Which factors influenced soil heterogeneity? As was the case with herb diversity, there are many different factors that can influence soil heterogeneity. However, we want to highlight a few factors which may have been important in the study area. A long history of uniform management can alter relations between vegetation and soil properties (Whitney 1991). Moreover, woody vegetation tends to increase heterogeneity of soil chemical properties (Wilson 1997). In our study the lower CV's of most soil parameters in pasture compared to coffee may indicate influence of land use on soil heterogeneity, although we realize that this difference in CV's was significant for only one parameter. Other important factors influencing soil heterogeneity in the study area may have been water erosion and landslides. Up to $63 \%$ of our study area is affected by erosion and shallow landslides (Schoorl et al. 2006). In some places the A-horizon with higher clay content and more organic matter is eroded, exposing the underlying sandy soils. This in turn affects drainage 
and nutrient availability. Especially in the upland soils which have steeper slopes, erosion and landslides are more pronounced and may cause higher habitat heterogeneity.

When analysing the combined effect of landscape position and heterogeneity of soil properties using GLM, herb diversity was best explained for coffee (almost 80\% of species richness was explained) followed by pasture and rice whose models explained much less of the variance, but still yielded significant models (Table 3.4). The high $\mathrm{R}^{2}$ in coffee may be explained by the relatively high contribution of forest understory species to plant diversity in coffee agroforestry. It has been suggested before that understory species are more sensitive to soil factors than herbs that receive more light, possibly because of the added stress of low-light conditions and competition with canopy trees for nutrients and water (Gentry 1988). The $44 \%$ of the variance of total herb diversity (gamma diversity) that could be explained for all land use systems is remarkable, especially considering that landscape position and soil properties are only seldom taken into account when explaining herb diversity. The percentage not explained by our model is probably caused by one or more of the many other factors than can affect plant diversity (Diamond 1988).

\subsubsection{Consequences for conservation measures}

Our study area falls within the Chocó biogeographical region, a global biodiversity hotspot, which has suffered heavy anthropogenic modification in recent decades. Nowadays, much of the area consists of managed land, and it is therefore appropriate to analyze how much each of the different land use types contributes to biodiversity. This is even more important if protected areas are going to be connected through so-called bio-corridors, in which management may be adapted for the benefit of biodiversity conservation. Our results show that landscape position and soil conditions are important factors that should be considered during the planning of conservation measures or bio-corridors. Furthermore, the high species turnover in coffee corroborates the importance of microhabitat heterogeneity of these agroforestry systems for biodiversity at the landscape level. Conservation strategies should therefore include financial and/or technical incentives to reverse the present trend where an increasing amount of coffee agroforestry is converted into pastures or rice fields due to low coffee prices and yields (Benitez et al. 2006). 


\section{Acknowledgements}

For field assistance we thank J. Lino, A. Choez, C. Calderón, C. Enriquez and J.C. Narváez. We are grateful to F. J. Cornejo for assistance with species identifications, and the Guayaquil Herbarium (GUAY) of Ecuador, for allowing us to use their reference collection. This research was carried out within the Bio-Sys project, which is part of the BioTEAM research program sponsored by the Federal Ministry of Education and Research, Germany $(<$ http://www.bmbf.de $>$ BMBF $)$. 


\section{4}

\section{The effect of erosion and sedimentation on soil organic carbon redistribution in a tropical landscape (Ecuador)}

\subsection{Introduction:}

In recent years, agriculture and land use change have contributed about $20 \%$ to the $\mathrm{CO}_{2}$ increase in the atmosphere with an annual rate of about $3.2 \times 10^{15} \mathrm{~g} \mathrm{C}$ (Lal 1995; IPCC 1996). Agricultural practices can lead to a reduction in ecosystems $C$ stocks due to the removal of aboveground biomass with subsequent burning (Mutuo et al. 2005), loss of soil organic carbon (soil C) as a result of decomposition (Davidson and Ackerman, 1993), and loss of soil C by erosion (Yoo et al. 2005). While the direct impact of land use changes on soil C pools and fluxes has been investigated widely (e.g. Lal et al. 1998a; b; Janzen et al. 1998; de Koning et al, 2003) the research effort on the effects of soil erosion and sedimentation on the $\mathrm{C}$ cycle is still limited, even though water erosion may be responsible

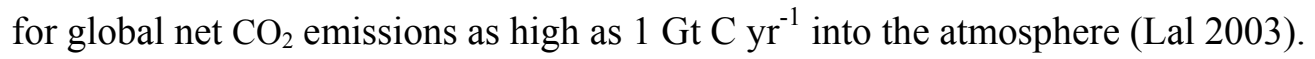

Soil erosion is a complex process, which involves four phases: detachment, breakdown of aggregates, transport/redistribution and sedimentation (Lal 2003). These four phases strongly influence the distribution and quantity of soil C in a landscape (Fang et al. 2006). Typically, erosion reduces the soil $\mathrm{C}$ storage at upper slopes and sedimentation increases the soil C storage at footslopes and depressions (Lui et al., 2003). The four phases of soil erosion depend strongly on land cover and land use, soil characteristics, landscape position and climate. Vegetation cover enhances infiltration and reduces surface runoff (Lee and Skogerboe 1985; Francis and Thornes 1990), and the variability in surface runoff (Kosmas et al. 2000). A study in eastern Spain, for example, demonstrated that the interaction of vegetation and parent material prevented high runoff and erosion rates on marl soils, when 
plant cover increase (Cerda 1999). Transport of soil material and redistribution over the landscape depends on its composition: the light fraction of organic matter and clay minerals are easier removed and redistributed over the landscape, than the heavier silt and sand fractions (Lal 1998a). Since topographical gradients and amount of running water are the principal drivers, landscape position (slope angle, convex and concave profile and plan curvature) highly influences soil redistribution processes and sediment deposition (Sawnson et al. 1988) and finally precipitation intensity, strongly influences soil erosion and sedimentation processes.

The physical processes of erosion and deposition affect soil $\mathrm{C}$ distribution in two ways. First, erosion and deposition can redistribute considerable amounts of soil $\mathrm{C}$ within a field, in a toposequence or even more distant sites within a watershed. Furthermore, erosion and deposition may alter the biological process of $\mathrm{C}$ mineralization in soil landscapes, (e.g. by indirect effects on vegetation, soil depth, water availability, soil organic carbon buried).

In the present study we wanted to evaluate how land-use changes affect the distribution of soil carbon within a complex landscape through the processes of erosion and sedimentation. We selected a landscape in coastal Ecuador, which is dynamic both in terms of land use changes and landscape processes. Our objectives were: 1) to estimate the present soil C content using landscape predictors for soil $\mathrm{C}$, such as slope, elevation, texture, land use and landscape position; 2) to estimate soil redistribution under the present situation and under different land use change scenarios using an erosion/sedimentation model; 3) to estimate the redistribution of soil $\mathrm{C}$ within the landscape caused by erosion processes, and its effect on total soil C stocks.

\subsection{Materials and Methods}

\subsubsection{Study Area}

\section{General study area description}

The study area is located in the southern part of Manabí province in western Ecuador between the following UTM coordinates (zone 17): 545.5 and $580.5 \mathrm{~km}(\mathrm{E}, \mathrm{W})$ and 9819.5 
and $9850.5 \mathrm{~km}(\mathrm{~S}, \mathrm{~N})$. The total area is slightly more than $1000 \mathrm{~km}^{2}$ and the used DEM has a resolution of $29 \mathrm{~m}$ (see Fig. 4.1). Elevation ranges from 80 to $760 \mathrm{~m}$ above sea-level, further analysis of slope and elevation classes are given by Schoorl et al. (2006). The study area is located within the Chocó biogeographical region, which is one of the world's hotspots of biodiversity (Myers et al. 2000) and therefore a priority area for the implementation of conservation measures. Mean annual temperature is $25^{\circ} \mathrm{C}$. The mean annual precipitation varies from $800-1300 \mathrm{~mm}$ (INAMHI 2002). The area has a distinct rainy season from January until May.

Figure 4.1: Location and DEM (Digital Elevation Model) of the research area in the Southwest of Ecuador, the small rectangle indicates the exact location of the study area.

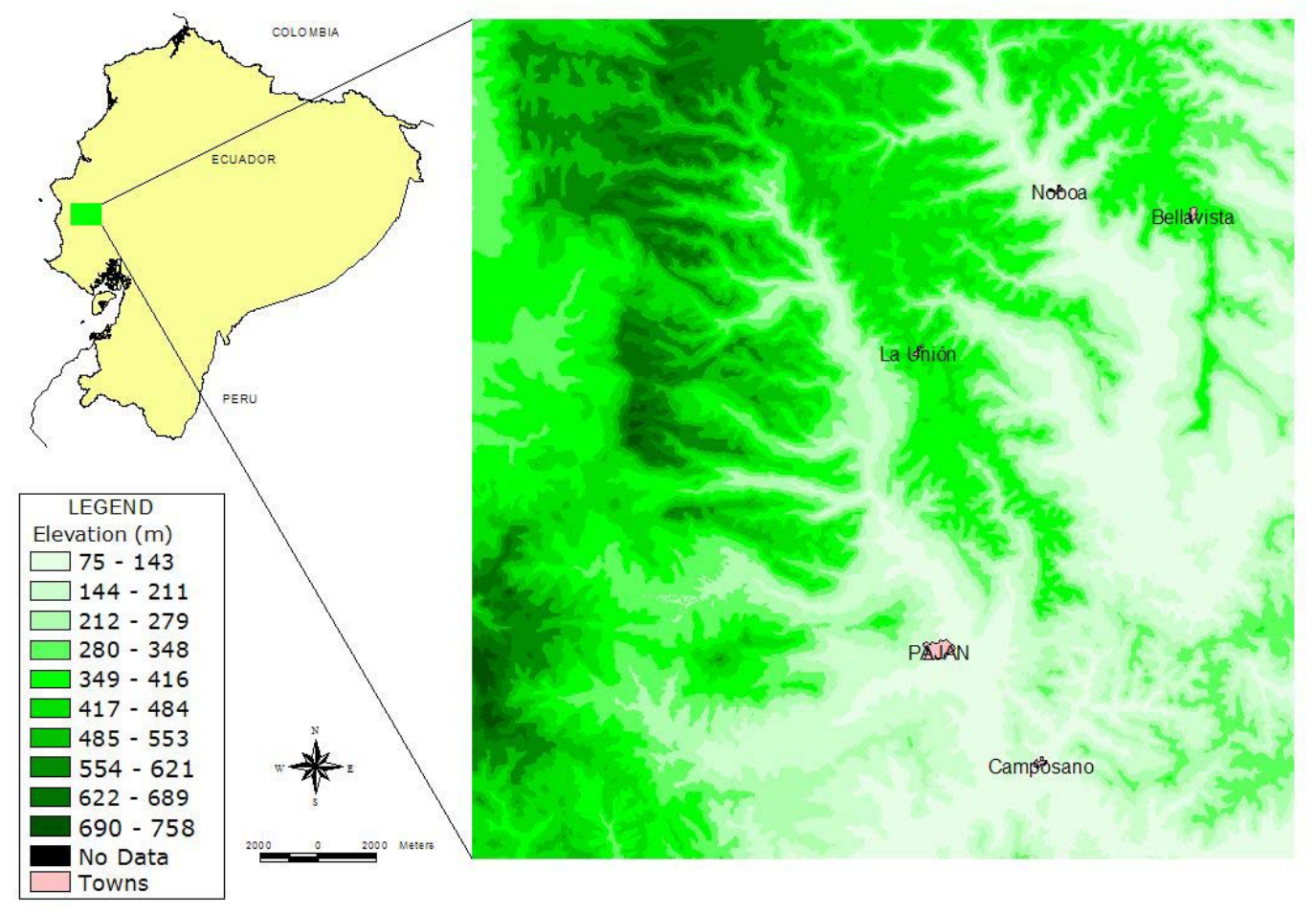

Natural vegetation in the area is semi-deciduous forest (Sierra 1999). The main agricultural land use systems are coffee agroforestry systems, pastures and upland rice fields (Unpublished land use map, Segarra, 2004). Coffee-agroforestry is an important land use system in this zone; more than $60 \%$ of the farmers in the area depend on in for their income 
(INEC, MAG and SICA, 2001). Furthermore, the semi-forest characteristics of coffee plantations represent an ideal habitat for many species of native fauna and flora. Consequently this land use system contributes considerably to the biodiversity in this region. Coffee agroforestry systems were establishment in the region 30 to 40 years ago by the replacement of the forest understory vegetation with coffee plants (mainly Coffea arabica L.) and planting of fruit trees and timber species with a multi-layered canopy structure.

Concerning the other land use systems, Pastures (consisting mainly of Panicum maximum Jacq.) have also been established approximately 30 years ago by sowing after slashing and burning of the original vegetation. Rice (Oriza sativa L.) plots were also established after slashing and burning of the original vegetation and/or agroforestry system. These plots are part of a rotation system with 4 to 5 years rice, followed by a fallow period of 2 to 3 years.

\section{Soils and geomorphology}

Two main physiographic units cover most of the area (see Fig. 4.1): river valleys with alluvial and colluvial deposits, situated south and southeast of the villages Pajan and Noboa and sloping areas including very steep slopes, mainly northwest of Pajan and Noboa (Schoorl et al. 2006). The geology and landscape genesis of the Noboa-Pajan region dates back to the Oligocene. Parent materials of the upland areas consist of sediments deposited by shallow marine (carbonates) to deep-sea currents or turbidites. The resulting layers (forming a Mesa landscape) have different particle sizes ranging from fine clays to silts and fine sands, which are typical for these turbidite settings (Kok and Michel, unpublished report). In sloping areas (ranging from 12 to over $35^{\circ}$ ), dominantly dystric leptosols can be found, especially where active erosion takes place in the study area. Throughout this paper we will refer to the soils developed on these sloping areas as 'upland soils'. In the valleys, dominantly dystric and mollic fluvisols are developed on alluvial deposits. We will refer to these soils as "lowland soils". Lowland soils are usually wetter than upland soils, because the water table is higher, and because water originating from higher areas is redistributed to the valley floor. 


\subsubsection{Site selection, Soil sampling and measurement of carbon stock}

We selected twelve plots of each of the three land use systems (36 plots in total). Plots were selected in such a way that six plots of each land use (18 plots) were located on alluvial fans and valley bottoms ('lowland soils'). The other (18 plots) were located on slopes ('upland soils'). The site locations were chosen to represent the major two soil-landscape classes with different topography, soil series and drainage.

At each georeferenced site, nine soil samples from a 3 × 3 regular grid were collected in April 2003, to quantify carbon concentration in the upper 0 to $0.25 \mathrm{~m}$ depth of the soil. In addition, at each point bulk density was determined by sampling an undisturbed soil sample using a $250 \mathrm{~cm}^{3}$ stainless steel cylinder. In the laboratory, soil samples were analyzed for total soil organic carbon (SOC) using an automated C \& N analyzer (Heraeus Vario EL) and bulk density was calculated after the soil was dried at $105^{\circ} \mathrm{C}$ in paper bags for 24 hours and then weighed. Soil organic carbon stock was calculated for each plot from the measured bulk density, soil organic carbon concentration and soil depth. Carbon stocks, elevation, slope and coordinates are summarised in the Table 4.1.

\subsubsection{Modelling and statistical analysis}

Determination of actual C content (baseline) with terrain-based environmental correlation

Using a General Linear Model (GLM) with backward stepwise elimination we developed a statistical model to calculate soil C stocks (dependent variable), with independent variables selected from the following set: elevation, slope and texture (sand dummy variable) for the 36 plots, including land use and soil landscape position corresponding to categorical variables. We chose these variables because they are known to influence soil C stocks (de Koning et al. 2003). Furthermore, we have complete GIS coverage for these variables for our study area, allowing extrapolation of the models based on plot data to the whole area. We examined the explanatory power of significant effects using a Type II Likelihood Ratio test. Assumptions of normality and homogeneity of variance were tested on all variables, prior to modelling the statistic tests. Using the statistical model, we calculated a soil carbon 
map for the whole study area. For all statistical analyses the GRM module of Statistica 6.0 (StatSoft, Inc. 2003) were used.

\section{Soil redistribution under four scenarios of land use change}

To calculate the amount of soil redistribution at landscape level, we used the LAPSUS modelling framework (Schoorl et al. 2001; Claessens et al. 2005). This model requires data of topography (in this study we used a DEM with $29 \mathrm{~m}$ resolution) and furthermore information on land use, geology, soil type, soil depth, rainfall, erodibility and soil infiltration rate. Attributes derived from the DEM are the local slope and the upslope contributing drainage area, which are calculated using the algorithm of multiple downslope flow (Quinn et al. 1991). Some input variables such as: erodibility, soil depth and soil permeability were not measured in the field but estimated based on expert knowledge, and depended on land use system and soil type (see Appendix 4.1).

First, we ran LAPSUS for actual land use, considering present topography and soil conditions in the area. This model run corresponds to scenario " 0 " or baseline conditions with which all subsequent scenarios were compared. To explore the possible changes in soil $\mathrm{C}$ storage in the area as a result of erosion and sedimentation, we defined four 'extreme' scenarios of land use change: scenario 1: conversion of all coffee to pasture; scenario 2: conversion of all coffee to rice; scenario 3: conversion of all rice to coffee; and scenario 4: conversion of all pasture to coffee. These four scenarios were run in LAPSUS (by adapting the parameter settings for the changed land use areas) to calculate the soil erosion and sedimentation over a period of 1 year. Each scenario produced new spatial and temporal patterns of total amounts of erosion and sedimentation throughout the landscape, which were combined with the SOC map, to calculate changes in soil carbon distribution at the landscape level. For all scenarios we assumed constant climatic conditions (same average rainfall every year).

We also stratified the area in 4 classes of soils based on texture (sand, clay and loam soils) and soil located in river terraces and river/stream valley areas (see soil class map in Fig. $4.2)$ to determine average soil redistribution by soil class.

\section{Balance}


We assumed that soil $\mathrm{C}$ within in the whole soil profile is in equilibrium in order to calculate the $\mathrm{C}$ redistribution by erosion and sedimentation processes. We used the following equations to calculate soil carbon losses and gains:

$\mathrm{C}_{\text {loss }}=\left(\mathrm{C}_{\text {soil }} *\right.$ Tot_ero $) /$ depth

$\mathrm{C}_{\text {gains }}=\left(\mathrm{C}_{\text {soil }} *\right.$ Tot_sed $) /$ depth

Where $\mathrm{C}_{\text {loss }}=$ soil organic $\mathrm{C}$ losses by erosion processes in the study area (corresponds to a negative value in $\mathrm{Mg} \mathrm{C} \mathrm{ha-1} \mathrm{yr}^{-1}$ ); $\mathrm{C}_{\text {gains }}=$ soil organic $\mathrm{C}$ gains by sedimentation processes in the watershed (correspond to positive value in $\mathrm{Mg} \mathrm{C} \mathrm{ha}^{-1} \mathrm{yr}^{-1}$ ); $\mathrm{C}_{\text {soil }}=$ mean soil organic carbon Stock ( $\mathrm{Mg} \mathrm{C} \mathrm{ha}^{-1}$ (data obtained from the soil C map of Fig. 4.3); Tot_ero = mean soil erosion losses $\left(\mathrm{m} \mathrm{yr}^{-1}\right)$ (data from LAPSUS Model); Tot_sed $=$ mean soil sedimentation gains $\left(\mathrm{m} \mathrm{yr}^{-1}\right)$; depth $=$ soil sampling layer $(\mathrm{m})$.

Figure 4.2: Soil Stratification

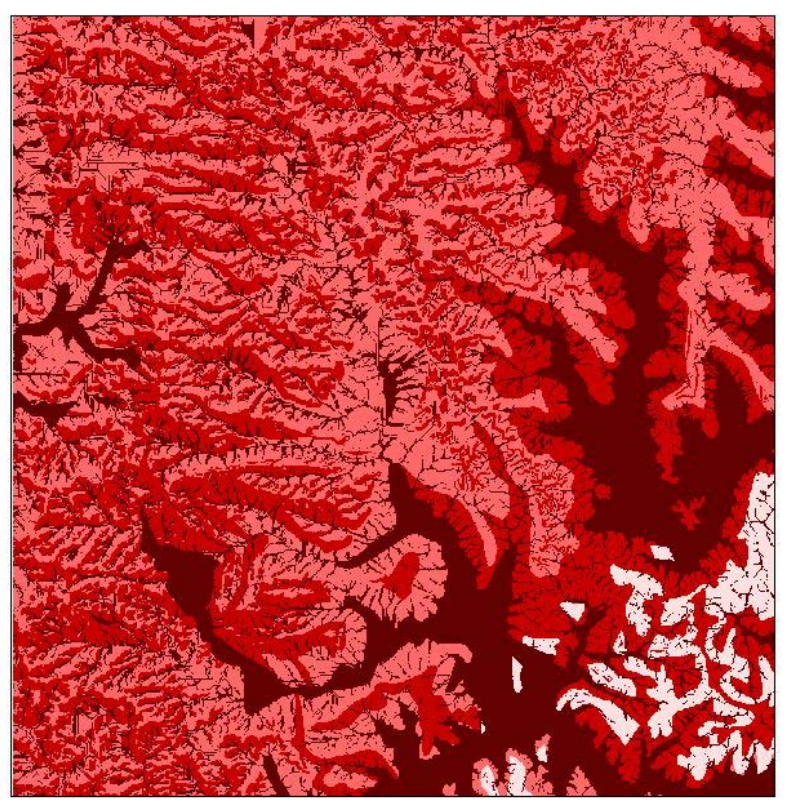

\section{Soil Classes}
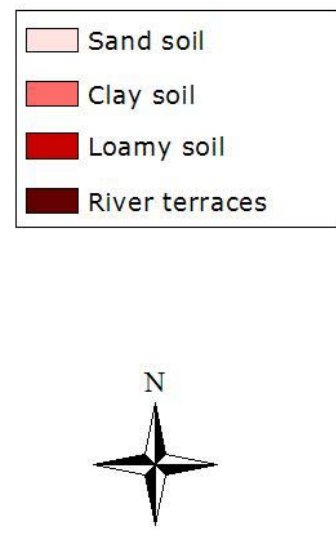

Graphic scale: 1:180000

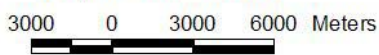


Table 4.1: Soil $\mathrm{C}$ concentration and soil $\mathrm{C}$ content and environmental variables

\begin{tabular}{|c|c|c|c|c|c|c|c|c|c|}
\hline ID & X (UTM) & $\mathrm{Y}(\mathrm{UTM})$ & Land use & Landform & C (mg) & $\mathrm{BD}\left(\mathrm{gcm}^{-3}\right)$ & $\mathrm{C}\left(\mathrm{Mgha}^{-1}\right)$ & Slope $\left({ }^{\circ}\right)$ & Elevation (m) \\
\hline 1 & 566670 & 9844870 & 1 & 1 & 30.92 & 1.10 & 84.88 & 0 & 145 \\
\hline 2 & 570482 & 9841336 & 1 & 2 & 25.14 & 1.11 & 70.00 & 3 & 228 \\
\hline 3 & 569803 & 9832226 & 1 & 1 & 20.75 & 1.10 & 56.87 & 0 & 132 \\
\hline 4 & 570716 & 9837024 & 1 & 1 & 24.42 & 1.09 & 66.54 & 0 & 126 \\
\hline 5 & 571246 & 9830485 & 1 & 1 & 34.12 & 1.00 & 85.10 & 0 & 148 \\
\hline 6 & 564191 & 9827161 & 1 & 1 & 32.81 & 1.00 & 82.29 & 0 & 136 \\
\hline 7 & 566837 & 9824511 & 1 & 1 & 23.36 & 1.15 & 67.01 & 0 & 125 \\
\hline 8 & 571993 & 9840142 & 1 & 2 & 23.46 & 1.09 & 63.65 & 15 & 198 \\
\hline 9 & 562322 & 9839314 & 1 & 2 & 22.55 & 1.18 & 66.51 & 20 & 467 \\
\hline 10 & 560303 & 9837364 & 1 & 2 & 18.52 & 1.10 & 50.78 & 5 & 471 \\
\hline 11 & 568651 & 9828048 & 1 & 2 & 28.70 & 1.17 & 83.64 & 30 & 194 \\
\hline 12 & 569064 & 9830574 & 1 & 2 & 36.11 & 1.09 & 98.51 & 2 & 190 \\
\hline 13 & 567846 & 9844972 & 2 & 1 & 21.24 & 1.11 & 59.14 & 16 & 160 \\
\hline 14 & 569843 & 9841319 & 2 & 2 & 20.02 & 1.23 & 61.74 & 5 & 180 \\
\hline 15 & 569533 & 9832121 & 2 & 1 & 21.97 & 1.15 & 63.26 & 12 & 130 \\
\hline 16 & 570866 & 9837350 & 2 & 1 & 26.15 & 1.11 & 72.58 & 10 & 136 \\
\hline 17 & 570410 & 9830749 & 2 & 1 & 33.43 & 1.11 & 92.44 & 0 & 121 \\
\hline 18 & 564587 & 9827113 & 2 & 1 & 20.86 & 1.27 & 66.23 & 0 & 125 \\
\hline 19 & 567452 & 9824316 & 2 & 1 & 14.86 & 1.32 & 49.15 & 3 & 160 \\
\hline 20 & 571780 & 9840111 & 2 & 2 & 38.03 & 1.05 & 99.59 & 8 & 186 \\
\hline 21 & 561598 & 9840014 & 2 & 2 & 23.67 & 1.08 & 63.80 & 20 & 477 \\
\hline 22 & 560441 & 9837259 & 2 & 2 & 25.98 & 1.07 & 69.37 & 15 & 471 \\
\hline 23 & 569287 & 9828324 & 2 & 2 & 15.65 & 1.35 & 52.81 & 34 & 193 \\
\hline 24 & 568947 & 9830546 & 2 & 2 & 30.44 & 1.21 & 92.23 & 10 & 187 \\
\hline 25 & 565629 & 9844318 & 3 & 1 & 21.83 & 1.18 & 64.25 & 0 & 156 \\
\hline 26 & 569801 & 9841059 & 3 & 2 & 22.56 & 1.14 & 64.11 & 9 & 179 \\
\hline 27 & 569803 & 9832126 & 3 & 1 & 17.19 & 1.08 & 46.42 & 0 & 126 \\
\hline 28 & 570716 & 9837018 & 3 & 1 & 16.15 & 1.01 & 40.94 & 0 & 126 \\
\hline 29 & 570695 & 9830614 & 3 & 1 & 22.12 & 1.01 & 55.73 & 0 & 119 \\
\hline 30 & 564833 & 9826975 & 3 & 1 & 17.35 & 1.24 & 54.00 & 0 & 120 \\
\hline 31 & 566908 & 9824383 & 3 & 1 & 19.42 & 1.32 & 63.91 & 25 & 105 \\
\hline 32 & 571901 & 9840298 & 3 & 2 & 23.78 & 1.22 & 72.69 & 12 & 189 \\
\hline 33 & 562412 & 9839223 & 3 & 2 & 22.02 & 1.08 & 59.61 & 8 & 471 \\
\hline 34 & 560684 & 9837713 & 3 & 2 & 17.95 & 1.12 & 50.29 & 10 & 470 \\
\hline 35 & 568962 & 9828204 & 3 & 2 & 23.58 & 1.24 & 72.83 & 20 & 175 \\
\hline 36 & 569064 & 9830574 & 3 & 2 & 28.16 & 1.15 & 80.67 & 2 & 190 \\
\hline
\end{tabular}

Land-use: 1 = Coffee, 2 = Pasture, 3 = Rice; Landform: 1 = Lowland soils, 2 = Upland soils 
To determine soil $\mathrm{C}$ redistribution within the study area, we calculate the soil $\mathrm{C}$ balance $\left(\mathrm{C}_{\text {balance }}\right)$ between soil $\mathrm{C}$ losses and soil $\mathrm{C}$ gains (difference between absolute values).

$\mathrm{C}_{\text {Balance }}=\left(\mathrm{C}_{\text {gains }}-\mathrm{C}_{\text {loss }}\right)$

If the $\mathrm{C}_{\mathrm{Balance}}$ is a negative value correspond to soil $\mathrm{C}$ exported out of the watershed (loss), whereas if $\mathrm{C}_{\text {Balance }}$ is a positive value is the soil $\mathrm{C}$ eroded, that had been deposited within the watershed area. $\mathrm{C}_{\text {balance }}$ was calculated for all four scenarios.

To know, what fraction of soil eroded is loss out of the study area, I calculated the delivery ratio (Tot_SD), which is the sediment fraction exported out of the watershed. If the Tot_SD is equal to 1 , this means that all soil eroded was exported out of the watershed, whereas if Tot_SD $=0$ all soil eroded is deposited within the watershed area.

Tot_SD $=1-($ Tot_sed/(Tot_ero*(-1)))

\subsection{Results}

\subsubsection{Calculation of Soil C baseline}

The environmental variables that explain soil $\mathrm{C}$ distribution at regional level were: elevation $(F=9.56 ; p=0.004)$, texture (sand with dummy) $(F=7.42 ; p=0.011)$, land use $(\mathrm{LU} 1=$ coffee; $\mathrm{LU} 2=$ pasture $)(\mathrm{F}=4.7 ; \mathrm{p}=0.017)$, and landscape position $(\mathrm{LSP} 1=$ lowland $)$ $(\mathrm{F}=10.8 ; \mathrm{p}=0.003)$, according to the following multiple linear regression:

$\mathrm{C}\left(\mathrm{Mg} \mathrm{ha}^{-1}\right)=87.4-0.06 *$ elevation $-10.9 *$ Sand $+4.8 * \mathrm{LU} 1+3.7 * \mathrm{LU} 2-8.3 * \mathrm{LSP} 1$

The highly significant model explained $46 \%$ of the variability in soil $\mathrm{C}$ contents $(\mathrm{F}=5.041$, $\mathrm{df}_{\text {model }}=5$ and $\mathrm{p}=0.0018$ ). Application of this model to all cells in the region using GIS, resulted in a soil $\mathrm{C}$ distribution map (Figure 4.3). The highest values of soil $\mathrm{C}$ (in the south 
east corner of the area) are found in river valleys, river terraces, and lower hills, while soil $\mathrm{C}$ stocks are lower in the higher upland soils (north-west corner of the map). Soil C stocks range from 30 to $87 \mathrm{Mg} \mathrm{C} \mathrm{ha}^{-1}$ and the overall mean is $63.6 \mathrm{Mg} \mathrm{C}^{-1}$. The soil $\mathrm{C}$ map illustrates that the actual SOC content is strongly related to topographic position (compare soil C map of the Fig. 4.3 with DEM of Fig. 4.1), which suggests that erosion and sedimentation processes play an important role in this specific watershed area.

\subsubsection{Impacts of erosion and sedimentation by land use change on SOC redistribution}

Soil erosion losses and sedimentation gains were strongly affected by the four land use change scenarios (Table 4.2). Scenario 2 (all coffee converted to rice) resulted in the highest losses through erosion (Tot_ero $=-311 \mathrm{t} \mathrm{ha}^{-1} \mathrm{yr}^{-1}$ ) and highest sedimentation

(Tot_sed $=88.5 \mathrm{t} \mathrm{ha}^{-1} \mathrm{yr}^{-1}$ ), while scenario 3 (from rice to coffee) resulted in the lowest erosion $\left(-113 \mathrm{tha}^{-1} \mathrm{yr}^{-1}\right)$ and sedimentation $\left(29.8 \mathrm{tha}^{-1} \mathrm{yr}^{-1}\right)$ rates.

Table 4.2: Results of soil erosion and sedimentation from LAPSUS model under different land use change. Scenario: $0=$ baseline (actual land use system); $1=$ conversion from all coffee to pasture; $2=$ conversion from all coffee to rice; $3=$ conversion from all rice to coffee; $4=$ conversion from all pasture to coffee.

\begin{tabular}{cccccc}
\hline \multicolumn{6}{c}{ Means $\left(\mathrm{t} \mathrm{ha}^{-1} \mathrm{yr}^{-1}\right)$} \\
\hline Scenario & Total area (ha) & (Tot_ero) & Tot_sed & Tot_out & Tot_SD \\
\hline 0 & & & & & \\
1 & 81255 & -124.2 & 34.8 & -89.4 & 0.72 \\
2 & 81255 & -161.0 & 39.2 & -121.8 & 0.76 \\
3 & 81255 & -311.4 & 88.5 & -223.0 & 0.71 \\
4 & 81255 & -113.4 & 29.8 & -83.6 & 0.74 \\
\hline
\end{tabular}

Tot_ero $=$ mean soil erosion to all study area

Tot_sed $=$ mean soil sedimentation to all study area

Tot_out $=$ the mean erosion leaving the area (Tot_ero plus Tot_sed)

Tot_SD $=$ the sediment delivery ratio, the fraction of the erosion that leaves the area

For all scenarios, the area affected by sedimentation (positive values) was much smaller compared to the area affected by erosion (legend with negative values) (see Fig. 4.4 a, b, c, d, e). Compared to the baseline study, the total amount of soil that leaves the area (Tot_out) 
was slightly lower in scenarios 3 and 4, while in scenario 1 and especially scenario 2 considerably more soil is lost from the area. Therefore the conversion from coffee to rice as is presently occurring in part of the area due to low coffee prices is the worst scenario in terms of soil conservation. Since, $\mathrm{C}$ loss and $\mathrm{C}$ gains are closely related to soil erosion and sedimentation (eqs. 1 and 2), C redistribution displayed a rather similar pattern (Figure 4.5).

For the whole region (Total) without stratification (see Fig 4.5a), the variation in soil $\mathrm{C}$ losses (negative values) ranged from 2.5 $\mathrm{Mg} \mathrm{C} \mathrm{ha}^{-1}$ from scenario 3, to $7.0 \mathrm{Mg} \mathrm{C}^{-1}$ in scenario 2. Whereas, sedimentation rates, maintain the same tendencies of variation, but with gains of soil C (see Fig. 4.5 b). The total $\mathrm{C}$ balance was negative at the landscape level (Ctot_out) for all scenarios (see Fig 4.5c); indicating that the net effect of erosion and sedimentation was a loss of $\mathrm{C}$ from the basin area. However, the conversion from rice and pasture to coffee compared to the baseline, resulted in relative gains of SOC (C Tot_out). While the conversion from coffee to pasture and rice resulted in a loss of SOC in relation to the baseline.

Stratification in texture classes (sand, clay and loam soil) and landscape position (soil located in river terraces) resulted in the highest impact on SOC redistribution in clay soils and soils located in river terraces, while the lowest impact was found for soil with a loamy and sandy texture in all scenarios (Figure 4.5a, 4.5b and 4.5c). Especially the river terraces were sensitive to sedimentation processes, as they occur in the lowest parts of the landscape. Therefore these soils are affected by both on-site as well as off-site processes In contrast, the lowest SOC loss corresponded to sandy soils, where the effect of land use is small (Fig 4.5c). In all cases, the strongest impacts of erosion and sedimentation on $\mathrm{C}$ redistribution occur in scenario 2 .

\subsection{Discussion}

\subsubsection{Soil C distribution related to environmental variables and land use}

Because of the spatial variation in soil $\mathrm{C}$ concentrations, it is generally difficult to determine soil $\mathrm{C}$ stocks in a landscape. But, our study illustrated that a considerable part of the spatial variation in soil $\mathrm{C}$ stocks could be predicted using topographical attributes like 
soil texture, land use and landform. Dependence of such attributes has been shown before (de Koning et al. 2003; Powers and Veldkamp 2005); but application of such relations to larger areas is more seldom (Pennock et al. 1994). Although the main topographic attributes (elevation and landscape position-lowland soil) correlated negatively with $\mathrm{C}$ content, the resulting map of soil $\mathrm{C}$ distribution showed higher $\mathrm{C}$ stocks in lowland soils than in upland soils. This apparent contradiction can probably be explained with the relatively low sand content (or high clay content) of the lowland soils. Our results agree well with earlier studies which also found decreasing soil $\mathrm{C}$ stocks with increasing elevation (Bergstrom et al. 2001; Chaplot 2001). The relation of relief, water erosion and its effect on SOC storage have also been demonstrated by Pennock et al. (1994) and Pennock and Van Kessel (1997).

\subsubsection{Soil redistribution under different land use change scenarios}

By analyzing soil redistribution, we do not only focus on the area suffering from land use change. Increasing erosion and run-off rates from upstream-located land use change may also have an impact on down-slope local run-on, erosion and sedimentation rates (Schoorl and Veldkamp 2001). Our results calculated for one year illustrate that the overall susceptibility of erosion is highly dependent on land use type. A higher proportion of land use types which do not have a permanent cover (e.g. rice) results in much higher soil redistribution rates than in the case of land use types with a permanent cover like e.g. pastures or coffee. However, it should be kept in mind that our calculated soil losses were

not calibrated against an independent dataset. The range of soil losses ( $\left.83-223 \mathrm{tha}^{-1} \mathrm{yr}^{-1}\right)$ are comparable with other studies, e.g. Ambassa-Kiki and Nill, (1999) and Schoorl et al. (2002), who found maximum erosion losses of 109 and $250 \mathrm{t} \mathrm{ha}^{-1} \mathrm{yr}^{-1}$ in Cameroon and Spain respectively. However, these studies were done in drier areas than our study area, where the precipitation is higher and more intensive which makes it hard to do direct comparisons. 
Figure 4.3: Calculated spatial soil carbon distribution

\section{CARBON DISTRIBUTION MAP}

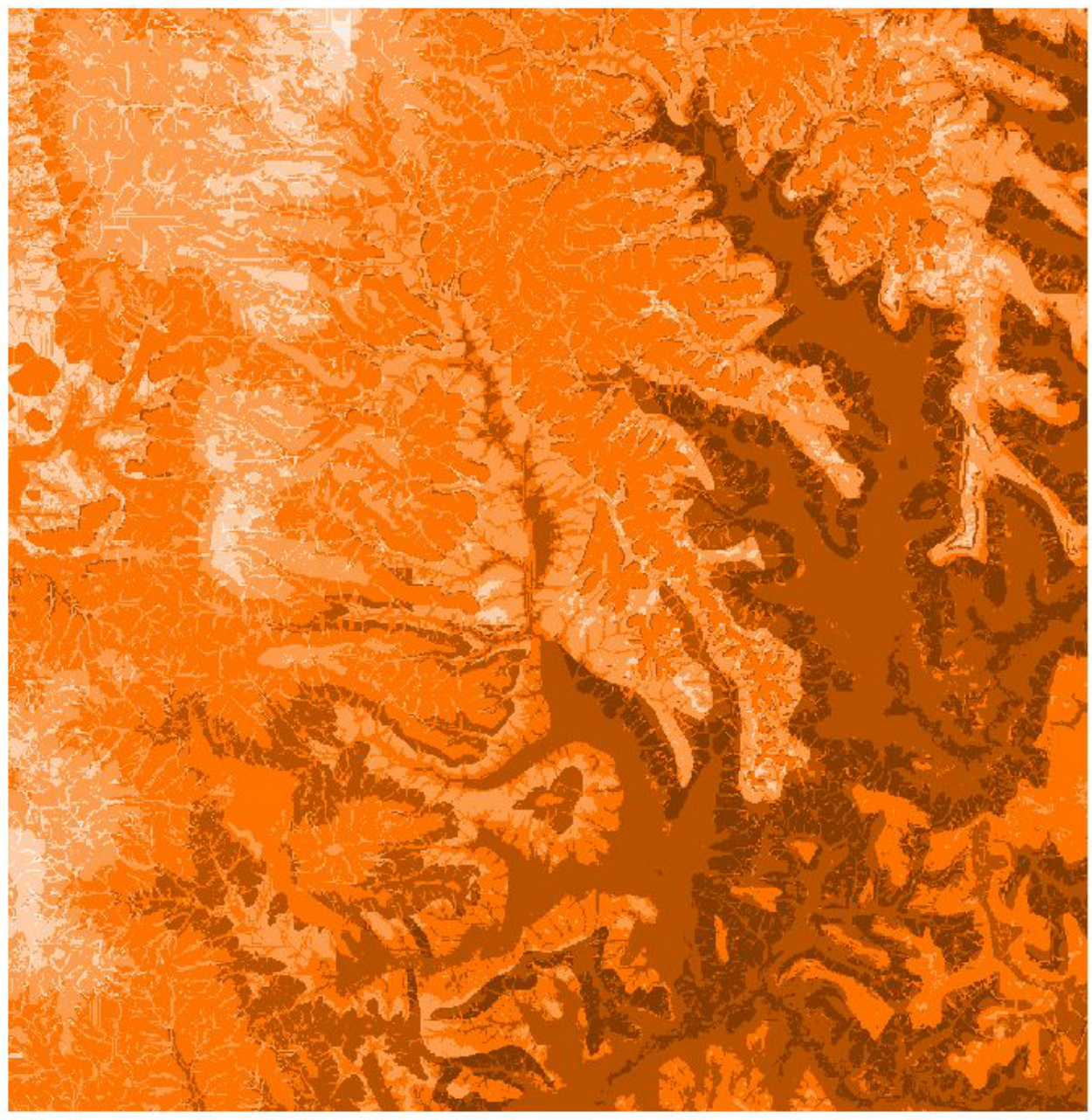

\begin{tabular}{|c|}
\hline $\mathrm{C}(\mathrm{Mg} / \mathrm{ha})$ \\
\hline$\square 30-39$ \\
\hline $39-49$ \\
\hline $49-58$ \\
\hline $58-68$ \\
\hline $68-77$ \\
\hline $77-87$ \\
\hline No Data \\
\hline
\end{tabular}

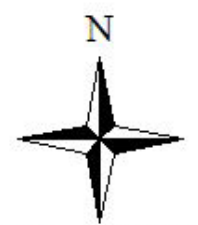

Scale: 1: 200000

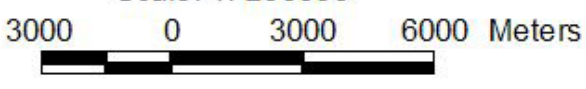


Figure 4.4: Annual soil redistribution in the landscape for 5 different scenarios, showing: erosion (negative values) and sedimentation (positive values).

\section{A) Scenario 0}

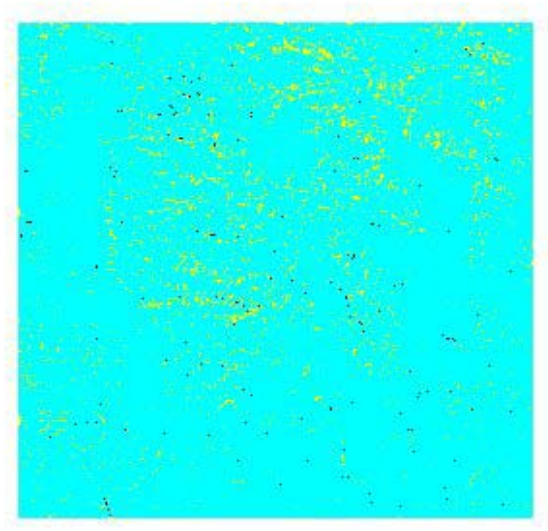

B) Scenario 1

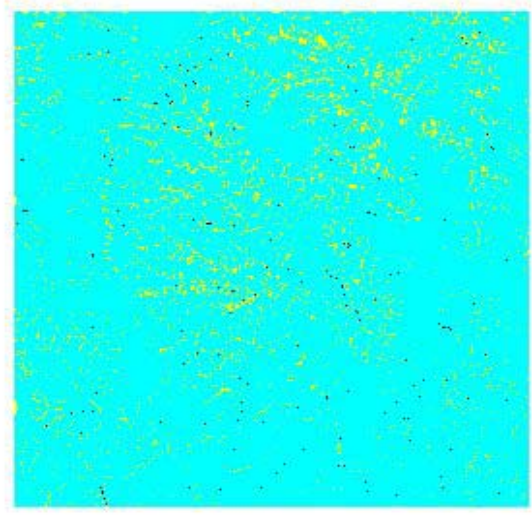

D) Scenario 3

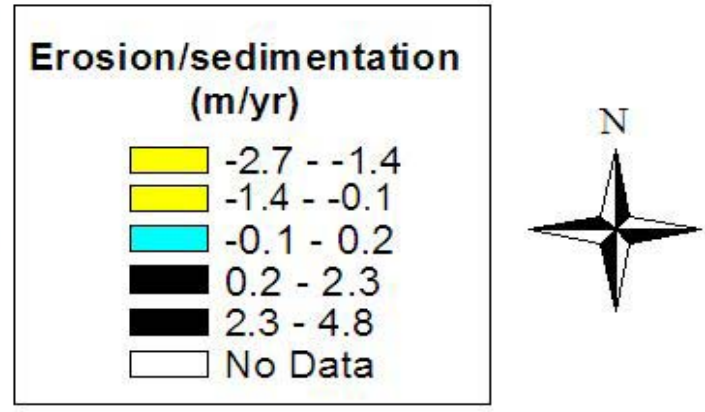

C) Scenario 2

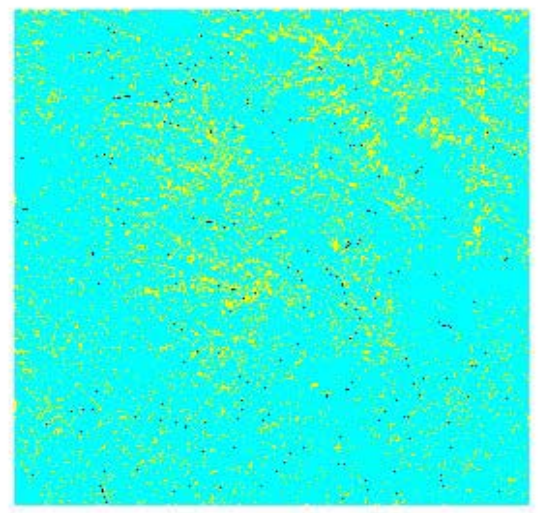

E) Scenario 4 
Our approach only concentrated on the redistribution of soil $\mathrm{C}$ on the basis of estimated carbon stocks. We did not consider the complete soil $\mathrm{C}$ balance (including $\mathrm{C}$ inputs and mineralization). That all our scenarios resulted in negative $\mathrm{C}$ balances does not necessarily mean that the total $\mathrm{C}$ balance for the study area was negative; it only means that the net effect of soil erosion and sedimentation was a removal of soil $\mathrm{C}$ from the study area. All land use systems also have $\mathrm{C}$ input through root and leaf litter and losses through mineralization, which will strongly influence the total $\mathrm{C}$ budget.

\subsubsection{The impact of land use change on soil redistribution and the soil C budget.}

As we expected, the total soil $\mathrm{C}$ loss from the study strongly depends on changes in land use (Fig. 4.5c). Agroforestry systems have the lowest losses of soil $\mathrm{C}$ especially in zones with clay soils and river/stream terraces. This land use system may therefore be considered for soil conservation and mitigation of carbon emissions. C losses from sand soils were approximately eight times lower than clay soil and soil located in river terraces or stream valley. High infiltration rates in sandy soils probably lead to much lower soil erosion rates than clay soils. Soils on river terraces and river/stream valley areas were most sensitive for erosional effects on the soil $\mathrm{C}$ balance. This demonstrates that the off-site effects on lowland soils were more important that the on-site consequences of land use change. Loamy soils, which are mainly located on footslopes and mid slope areas, suffered less from erosion processes. A study in Spain, also found lowest erosion on sand soils than in loam and clay soils under three vegetation covers (Cerda 1999).

We used a simple mass balance approach in which we multiplied the average value of soil $\mathrm{C}$ with soil removed. Although this approach probably results in a reasonable estimate of short term effects of soil redistribution on the soil $\mathrm{C}$ balance, the results should be interpreted with care if long-term effects are considered. For example we did not consider effects of erosion and sedimentation on $\mathrm{C}$ mineralization, nor do we know what happened to the soil $\mathrm{C}$ that was exported from the study area. Part of this carbon is deposited in terrestrial deposits, while another part is exported to aquatic ecosystems (Stallard 1998; Hope et al. 1994; Ludwing et al. 1996). 
Figure 4.5: Average soil C loss, gains and total balance by soil redistribution due to erosion and sedimentation processes on total and stratify study area.
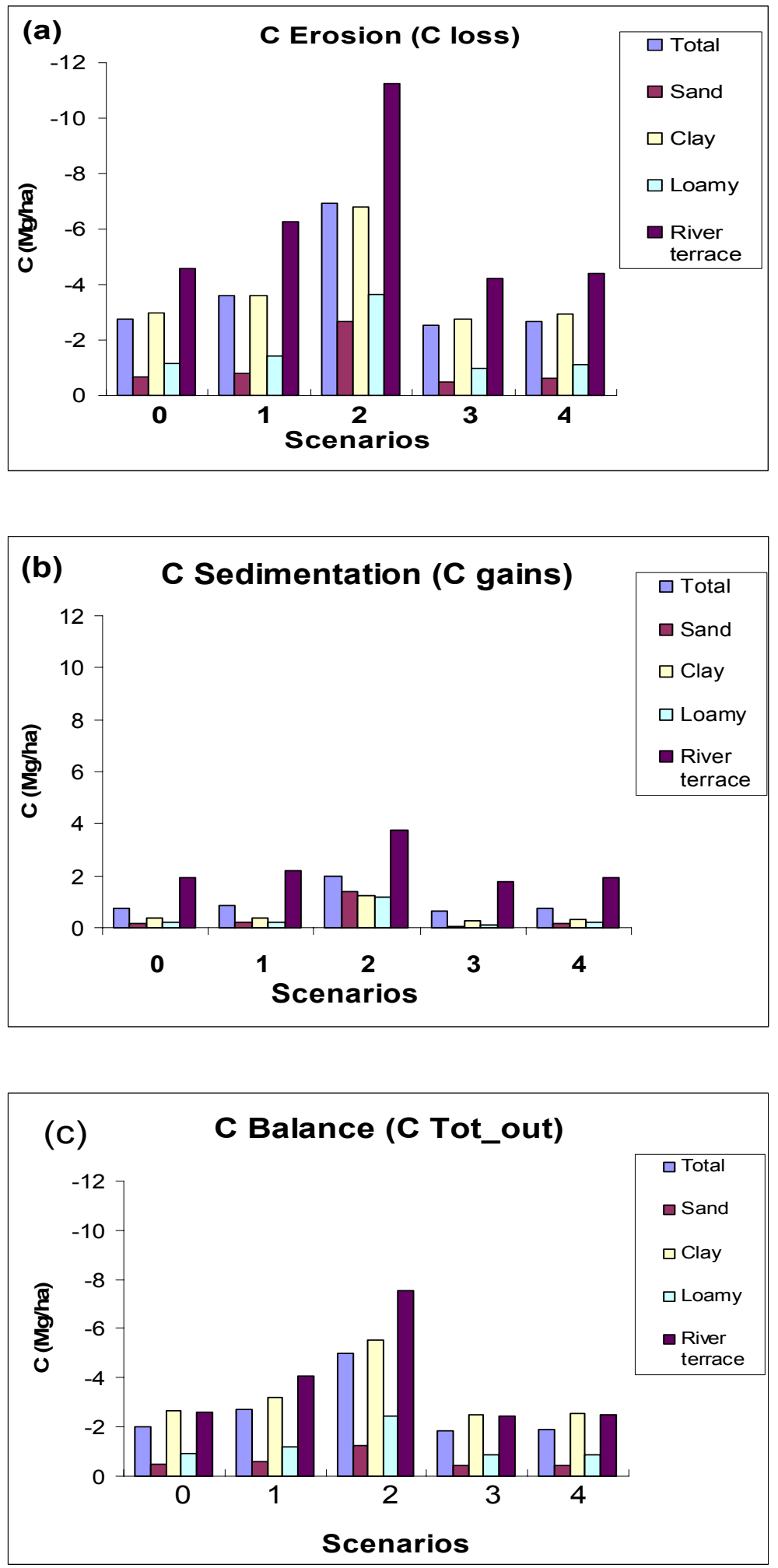
However as much as $70 \%$ of the exported $\mathrm{C}$ may be decomposed during transportation and deposition (Beyer et al. 1993) although other studies use lower estimates (about 20\%; Lal 1995 and Jacinthe et al. 2001). These differences show that presently not enough is know about the fate of eroded soil $\mathrm{C}$. However, creation of a $\mathrm{C}$ budget at the landscape level as we did in the present study is a step towards model development in which all processes affecting erosion, transport, and deposition and mineralization processes are considered. 


\section{5}

\section{Conclusions and further Research}

\subsection{Introduction}

The research presented in chapters 2 to 4 deals with case studies of a wide variety of soil ecological processes and services. The separate chapters include details about methodology main results and concluding paragraphs. In the present chapter a synthesis of the major findings in relation to the original research questions from chapter 1.2 will be discussed. Finally, some recommendations for further research are given.

\subsection{Research questions}

In Section 1.2 I presented three major research questions for the present thesis. Below these research questions are repeated, followed by the main conclusions:

i) How do soils affect $C$ sequestration and how does this change under different land use systems?

The case study on soil $\mathrm{C}$ sequestration showed that $\mathrm{C}$ stocks in the soil depend on the mechanisms of $\mathrm{C}$ stabilization that vary with different soil types. In Andisols, more soil C was stabilized than in Inceptisols and stabilization was mainly through complexation of Al, Fe with organic matter. In Inceptisols, C stabilization occurred through sorption by clay. When land use change occurred, neither Inceptisols nor Andisols showed indications that the processes that are responsible for the long-term ( $>30 \mathrm{yrs}$ ) stabilization of soil C played a role in the stabilization of more recently incorporated soil $\mathrm{C}$. The reason may be that soil C turnover in these stabilized pools is so slow that in the few decades that these land use changes had taken place no significant changes have occurred. 
ii) How do soils affect biodiversity and how does this change under different land use systems?

The case study on biodiversity showed that soil heterogeneity was a better predictor of herb diversity than soil properties per se, and landscape heterogeneity also contributed to plant diversity. Therefore, soil and landscape heterogeneity may be important criteria for the selection of areas for conservation. Although heterogeneity or diversity at soil level influenced diversity at plant level in this diverse tropical region, the strength of this effect decreased with intensity of management (strongest in agroforestry systems and weakest in rice). The results show that soil characteristics influence plant diversity, even if in managed ecosystems, but that a more intensive land use may actually reduce the contribution of soils to plant diversity.

iii) How do soil and land use affect soil erosion and deposition and how does this in turn affect soil C sequestration?

The case study on soil erosion and sedimentation showed that land use strongly affected erosion and deposition. Expansion of agroforestry systems in this area would simultaneously reduce soil erosion, enhance soil fertility, and increase soil C sequestration. Furthermore it was shown that the landscape scale application in the study area made it possible to identify places that need most attention and effort to prevent erosion and therefore soil $\mathrm{C}$ losses. In the study region, areas most susceptible to erosion were the river terraces.

These studies have shown that it is possible to do a quantitative investigation of soil functions which go beyond a traditional 'black box' approach. Furthermore it was possible to quantify the effects of land use and land cover changes on soil properties which have implications for devising land management strategies for sustainable use. This makes clear that the choices we make today in how we use land resources will have large consequences on the future sustainability of earth's ecosystems and the services they provide. 


\subsection{Recommendation for further research}

The results of this thesis can be used as a basis for model development to evaluate the effect of different land use scenarios on soil ecosystem services. Although several soil ecosystem services were discussed, it is necessary to include other soil environmental services as well such as water conservation. Soil ecosystem services are highly interdependent, so that a future goal should be the investigation of trade-offs between different ecosystem services as a result of land use changes. In such an analysis it would be critical to avoid irreversible

losses of some of these services and at the same time the identification of land use change scenarios that may lead to 'win-win' situations.

Future research effort on soil erosion and deposition should include more detailed studies to determine the fate of displaced soil $\mathrm{C}$ by erosion, and to evaluate what fraction is mineralized during transport to lower landscape positions. Furthermore the effects of burial and aggregation on soil $\mathrm{C}$ decomposition under aerobic and anaerobic conditions should be quantified. These are mere examples of important research issues, which can be effectively addressed by multi-disciplinary teams.

I hope that this thesis also will increase the awareness that it is necessary to integrate biophysical knowledge and the spatial distribution of natural resources in an economic framework to evaluate the consequences of land use changes. Within the BioSys project economic models for the payment of environmental services have been developed. Without the biophysical information generated in this thesis it would not be possible to optimize land use change scenarios which can be provided to decision makers to develop conservation strategies. 


\section{6}

\section{Summary}

Soils provide ecosystem services which are natural functions of an ecosystem that can also be used for the benefits of humans. In recent years there is an increasing awareness that ecosystem services are important for human well being, however the ecosystem services that soils provide are not well quantified. In the present thesis, some ecosystem services provided by soils are quantified in several study areas of coastal Ecuador. Furthermore the impact of different land uses on these ecosystem services is investigated. The chapters of this thesis are the result of two different projects that focused on the implementation of payment for ecosystem services for soil $\mathrm{C}$ sequestration and biodiversity, which is illustrated by the contents of the different chapters.

\section{(1) Stabilization mechanisms of soil carbon.}

The influence of soil C stabilization mechanisms is normally not considered in studies on the effects of land use changes. Instead, observed changes are typically explained by differences in litter input. As a result, it is not well known if and how quickly newly incorporated carbon is stabilized in soils. The goal of this chapter was to find out how much soil C was stabilized in two different soil orders (Andisols and Inceptisols) and which are the responsible mechanisms of C-stabilization. Furthermore, I looked for evidence that newly incorporated soil carbon was stabilized in these contrasting soil orders. 25 sites were selected in north-western Ecuador with two paired plots per site: one plot where pasture was converted to secondary forest and one plot where forest was converted to pasture. In all the plots soil carbon content, stocks and stable isotope $\left(\delta^{13} \mathrm{C}\right)$ signal were measured in the surface soil. $\delta^{13} \mathrm{C}$ values were used to estimate the stocks of soil $\mathrm{C}$ derived from forest (Cdf) and from pasture (Cdp) in all plots. I calculated correlations between these stocks and soil and environmental characteristics to identify mechanisms of soil $\mathrm{C}$ stabilization. The results show that long-term stabilization in Andisols was through formation of metal-humus complexes and allophane while in Inceptisols long-term stabilization was through sorption to clay minerals. I found evidence that recently incorporated carbon was not stabilized in Andisols, while in Inceptisols poorly crystalline (hydr-) oxides seemed to have stabilized 
part of this soil C. I conclude that unless soil C stabilizing mechanisms are explicitly considered, it will not be able to predict the direction and magnitude of changes in soil $\mathrm{C}$ stocks following land use changes in the tropics.

(2) The influence of soil and landscape characteristics on plant diversity.

Although it is clear that soil characteristics and natural plant diversity are intimately related, many of the relationships between specific soil properties and components of plant diversity in different human-dominated ecosystems remain little studied and often contradictory. In this study the influence of a range of soil properties and their heterogeneity on beta and gamma diversity in three land use systems and over two landscape positions in a tropical fragmented landscape are investigated in western Ecuador. The land use systems studied were, with increasing human interference, coffee agroforestry systems, pastures and rice. In all land use systems, beta diversity comprised the major part of total herb species diversity, with the highest relative beta diversity in coffee agroforestry systems, although this land use type had the lowest total species richness. I show that in all land use systems, herb diversity was positively correlated with heterogeneity of various soil properties. Soil heterogeneity (expressed as coefficient of variation of properties within plots) was a better predictor of herb diversity than values of soil properties per se. With general linear models, it was shown that for all land use types combined, over $40 \%$ of gamma diversity could be explained with the fixed factors land use type and landscape position, in combination with soil heterogeneity (specifically the heterogeneity of magnesium). When looking at land use types separately, up to $80 \%$ of gamma diversity in coffee agroforestry could be explained by landscape position and heterogeneity of magnesium. Although for pasture and rice lower percentages of herb diversity could be explained (32\%), soil heterogeneity was still a significant predictor. Landscape position was expressed by higher herb diversity in upland soils than in lowland soils, probably as a result of drainage problems in lower lying areas. The results show that soil- and landscape heterogeneity contribute to plant diversity and are therefore important aspects to consider when planning conservation measures.

3) The effect of erosion and sedimentation on soil organic carbon redistribution.

Land use changes may increase soil erosion and consequently losses of nutrients and soil organic carbon (soil C) stocks. Many studies on erosion have considered soil losses without taking into account deposition or sedimentation process. In this chapter, I evaluate how 
erosion and sedimentation soil processes affect the $\mathrm{C}$ balance in a watershed area in Western Ecuador. Using a mass balance approach, I first calculate the amount of soil C losses and gains caused by erosion, transport and deposition under present land use. It was then analyzed what would be the effect of different land use change scenarios compared to the present situation. I found that on soils with a sand texture, land use changes did not affect the $\mathrm{C}$ balance at watershed level, while that on soils with a clay or loam texture and specially in river terraces, changes in land use had a major impact on the redistribution of soil C. Conversion from agroforestry system to upland rice (a land use system in which soil is bare for some period of time) led to large soil $\mathrm{C}$ losses from the watershed while the opposite was true if rice field were converted into agroforestry systems. This study showed that soil $\mathrm{C}$ redistribution by erosion and sedimentation processes strongly depends on land use change and parent material.

The results of this thesis can be used as a basis for model development to evaluate the effect of different land use scenarios on soil ecosystem services. Although several soil ecosystem services were discussed, it is necessary to include other soil environmental services as well such as water conservation. Soil ecosystem services are highly interdependent, so that a future goal should be the investigation of trade-offs between different ecosystem services as a result of land use changes. In such an analysis it would be critical to avoid irreversible losses of some of these services and at the same time the identification of land use change scenarios that may lead to 'win-win' situations. In conclusion, these different studies show that it is possible to do a quantitative investigation of soil functions which go beyond a traditional 'black box' approach. Moreover, the soil biophysical information as was generated in this thesis will help to optimize land use change scenarios. Such scenarios can help decision makers to develop strategies for conservation and sustainable land use practices.

\subsection{Zusammenfassung}

Böden erfüllen auf natürliche Weise Ökosystemleistungen, die auch für menschliche Bedürfnisse genutzt werden können und werden. In den letzten Jahren ist das Bewusstsein gewachsen, dass Ökosystemleistungen bedeutend für das menschliche Wohlergehen sind. Nichtsdestotrotz sind die Ökosystemleistungen von Böden unzureichend quantifiziert. In 
der vorliegenden Dissertation werden einige Ökosystemleistungen quantifiziert. Dies geschah in mehreren Studiengebieten in den Küstengebieten Ecuadors. Des weiteren wird der Einfluss verschiedener Ladnutzungsarten auf diese Ökosystemleistungen untersucht. Die Kapitel dieser Dissertation sind das Ergebnis von zwei verschiedenen Projekten. Beide zielen darauf $a b$, die Umsetzung für eine Bezahlung von Ökosystemleistungen durch die Sequestrierung von Bodenkohlenstoff und die Biodiversität $\mathrm{zu}$ untersuchen. Dies wird durch die Inhalte der jeweiligen Kapitel veranschaulicht.

(1) Stabilisierungsmechanismen von Bodenkohlenstoff.

Der Einfluss von Stabilisierungsmechanismen des Kohlenstoffs in Böden bleibt bei Studien, die Landnutzungsänderungen analysieren normalerweise unberücksichtigt. Stattdessen werden beobachtete Effekte üblicherweise durch Unterschiede im Streueintrag erklärt. Es ist unzureichend bekannt, ob und wie schnell neu eingetragener Kohlenstoff im Boden stabilisiert wird. Ziel dieses Kapitels ist es herauszufinden, wie viel Bodenkohlenstoff in zwei verschiedenen Bodentypen (Andisole und Inceptisole) festgelegt wird und welche die hierfür verantwortlichen C-Stabilisierungsmechanismen sind. Des weiteren suchte ich Hinweise, ob neu eingetragener Bodenkohlenstoff in diesen kontrastierenden Bodentypen stabilisiert wurde. 25 Standorte wurden im Nordwesten von Ecuador mit zwei gepaarten Flächen pro Standort ausgewählt: eine Fläche, wo Weide zu Sekundärwald und eine Fläche, wo Wald zu Weide umgewandelt wurde. An allen Standorten wurden Gehalte und Vorräte des Bodenkohlenstoffs sowie deren stabile Isotopensignatur $\left(\delta^{13} \mathrm{C}\right)$ im Oberboden bestimmt. $\delta^{13} \mathrm{C}$ Werte dienten an allen Standorten zur Schätzung der weide- (Cdp) und waldbürtigen (Cdf) Vorräte des Bodenkohlenstoffs. Ich berechnete Korrelationen zwischen diesen Vorräten, dem dazugehörigen Boden und dessen ökologischen Eigenschaften um die Mechanismen der Kohlenstoffstabilisierung zu identifizieren. Die Ergebnisse zeigen, dass in den Andisolen eine Langzeitstabilisierung durch Bildung von Metal-Humus-Komplexen und durch Allophan stattfindet, während in den Inceptisolen Kohlenstoff durch Sorption an Ton dauerhaft stabilisiert wird. Ich fand Hinweise, dass neu eingetragener Kohlenstoff in Andisolen nicht stabilisiert wurde, während Inceptisole durch die Anwesenheit schwach kristalliner Hydroxide und Oxide offenbar neuen Kohlenstoff stabilisieren konnten. Daraus folgere ich, dass es nicht möglich ist, die Richtung und Größenordnung der Veränderungen in den Bodenkohlenstoffvorräten nach Landnutzungsänderung in Tropen vorherzusagen, solange die Stabilisierungsmechanismen nicht explizit berücksichtigt werden. 
(2) Der Einfluss charakteristischer Boden- und Landschaftseigenschaften auf die Diversität von Pflanzen

Obwohl bekannt ist, dass Bodeneigenschaften und natürliche Diversität von Pflanzen eng miteinander verknüpft sind, bleiben viele dieser Beziehungen zwischen spezifischen Bodeneigenschaften und Komponenten der floristischen Diversität in unterschiedlich stark vom Menschen dominierten Ökosystemen nur unzureichend untersucht und sind häufig widersprüchlich. In dieser Studie wird der Einfluss einer Spannweite von Bodeneigenschaften und ihrer Heterogenität auf die Beta und Gamma Diversität an drei Landnutzungssystemen sowie zwei Geländepositionen in einer stark gegliederten tropischen Landschaft in Westecuador untersucht. Die untersuchten Systeme waren in steigender menschlicher Nutzungsintensität: Agroforstsystem mit Kaffeanbau, Weide und Reis. In allen Landnutzungssystemen stellt die Beta Diversität den größten Teil der gesamten Diversität der Krautspezies dar. Die Beta Diversität war relativ im Agroforstsystem am höchsten, obwohl dieser Landnutzungstyp die geringste Gesamtartenzahl aufwies. Ich zeige, dass in allen Landnutzungssystemen, die Diversität der Kräuter positiv mit der Heterogenität verschiedener Bodeneigenschaften korreliert. Die Heterogenität des Bodens (ausgedrückt als Koeffizient der Varianz verschiedener Eigenschaften innerhalb der Flächen) war ein besserer Vorhersageparameter der floristischen Diversität als Werte der Bodeneigenschaften per se. Mit allgemeinen linearen Modellen konnte gezeigt werden, dass für alle Landnutzungsarten zusammen über $40 \%$ der Gamma Diversität durch die unabhängigen Variablen Landnutzungstyp und Geländeposition verbunden mit der Heterogenität des Bodens (im besonderen die Heterogenität von Magnesium) erklärt werden konnten. Werden die Landnutzungsarten jedoch einzelnen betrachtet, so kann bis zu $80 \%$ der Gamma Diversität in dem Kaffeagroforst durch die Geländeposition und durch die Heterogenität von Magnesium erklärt werden. Obwohl für Weide und Reis geringere Prozentsätze der Diversität der Kräuter (32\%) erklärt werden konnten, war die Bodenheterogenität ein signifikanter Vorhersageparameter. Geländeposition wurde durch eine höhere Diversität der Kräuter in den Böden im Bergland als in den Böden im Tiefland charakterisiert, höchstwahrscheinlich als Ergebnis von Drainageproblemen in den tiefer gelegenen Gebieten. Die Ergebnisse zeigen, dass das das Zusammenspiel der Heterogenität von Böden und Landschaft die Diversität der Pflanzen steuern und deshalb als wichtige Aspekte bei der Planung von Schutzgebietsausweisung zu berücksichtigen sind. 
(3) Effekt von Erosion und Sedimentation auf die Verteilung von organischem Bodenkohlenstoff.

Änderungen in der Landnutzung können die Bodenerosion erhöhen und demnach Verluste von Nährstoffen und Vorräten des Bodenkohlenstoffs bewirken. Viele Erosionsstudien haben die Verluste des Boden untersucht ohne auf die Prozesse während der Wiederablagerung oder Sedimentation zu berücksichtigen. In diesem Kapitel bewerte ich wie Erosion und Sedimentation die C-Bilanz in einem Wassereinzugsgebiet im Westen von Ecuador beeinflussen. Auf einem Massenbilanzansatz basierend, berechne ich zuerst die Mengen von Verlusten und Gewinnen des Bodenkohlenstoffs, die durch Erosion, Transport und Ablagerung unter den Bedingungen der gegenwärtigen Landnutzung hervorgerufen werden. Anschließend wurden Szenarien von veränderter Landnutzung im Vergleich zur aktuellen analysiert. Dabei fand ich heraus, dass die C-Bilanz auf der Ebene des Wassereinzugsgebietes in Böden mit sandiger Textur nicht durch Landnutzungsänderungen verändert wurde, während in Böden mit toniger oder lehmiger Textur und hier im besonderen in Flussterrassen Landnutzungsänderungen einen großen Einfluss auf die Verteilung von Bodenkohlenstoff hatten. Die Umwandlung von Agroforst zu Reisfeldern im Bergland (eine Nutzung, bei dem der Boden für einige Zeit frei von Vegetation ist) führten zu großen Verlusten von Bodenkohlensstoff im Wassereinzugsgebiet, während das Gegenteil gefunden wurde, wenn Reisfelder in Agroforst umgewandelt wurden. Diese Studie zeigt, dass die Umverteilung von Bodenkohlenstoff durch Erosions- und Sedimentationsprozesse stark von Landnutzung und Ausgangsmaterial gesteuert wird.

Die Ergebnisse dieser Dissertation können als Basis zur Entwicklung von Modellen dienen, um den Effekt verschiedener Landnutzungsszenarien auf die Ökosystemleistungen des Bodens zu bewerten. Obwohl mehrere Ökosystemleistungen des Bodens diskutiert werden, ist es notwendig, noch weitere Leistungen, wie z.B. den Grundwasserschutz mit zu berücksichtigen. Ökosystemleistungen des Bodens sind stark miteinander gekoppelt, so dass ein zukünftiges Ziel sein sollte, die gegenseitigen Wirkungsbeziehungen zwischen verschiedenen Ökosystemleistungen als Ergebnis von Landnutzungsänderungen zu untersuchen. In einer solchen Untersuchung wäre es entscheidend, irreversible Verluste von Ökosystemleistungen zu vermeiden und gleichzeitig Szenarien der Landnutzungsänderung zu identifizieren, die zu 'win-win` Situationen führen könnten. Zusammenfassend zeigen 
diese Studien, dass es möglich ist, eine quantitative Untersuchung über Bodenfunktionen durchzuführen, die über den traditionellen 'black box' Ansatz hinaus geht. Zusätzlich wurden in dieser Dissertation Informationen über biophysikalische Eigenschaften des Bodens erhoben, die helfen Szenarien der Landnutzungsänderung zu verbessern. Solche Szenarien können Entscheidungsträgern helfen, Strategien für die Bewahrung und die nachhaltige Nutzung von Ökosystemen zu entwickeln.

\section{2 Resumen}

Los suelos proveen servicios que corresponden a funciones naturales del ecosistema, y que pueden ser usados para beneficio del hombre. En los recientes años se ha incrementado la concientización de que los servicios de los ecosistemas son importantes para el bienestar de la humanidad, sin embargo el impacto de los servicios que provee el suelo no son bien cuantificados. En la presente tesis, algunos de los servicios de los ecosistemas proporcionados por el suelo son cuantificados en varias áreas de estudio en la costa del Ecuador. Además el impacto de los diferentes usos del suelo en esos ecosistemas es investigado. Los capítulos de esta tesis son el resultado de dos proyectos diferentes, que se enfocaron en la implementación de pagos por servicios ambientales de los ecosistemas, específicamente fijación de carbono y biodiversidad, como se ilustra en los contenidos de los diferentes capítulos.

(1) Los mecanismos de estabilización de carbono en el suelo:

La influencia de los mecanismos de estabilización de $\mathrm{C}$ en el suelo normalmente no son considerados en los estudios de los efectos por cambio de uso del suelo. En tanto, los cambios observados son explicados típicamente por las diferencias en la entrada de hojarasca. Como resultado, no se conoce bien cuanto del carbono que rápidamente es recientemente incorporado al suelo se estabiliza. La meta de este capítulo fue averiguar la cantidad de $\mathrm{C}$ que se estabilizó en dos órdenes diferentes de suelo (Andisoles e Inceptisoles) y cuales son los mecanismos responsables de C-estabilización. Además, se buscaba evidencias de que el carbono recientemente incorporado al suelo fue estabilizado en estos dos contrastantes órdenes del suelo. Se seleccionaron 25 sitios al noroccidente del Ecuador, con dos pares de parcelas por sitio: una parcela dónde pasto fue convertido a bosque secundario y una parcela dónde el bosque secundario fue convertido a pasto. En 
todas las parcelas la cantidad de carbono, contenidos y señal del isótopo estable $\left(\delta^{13} \mathrm{C}\right)$ fueron medidos en el suelo superficial. Los valores de $\delta^{13} \mathrm{C}$ y contenidos totales de $\mathrm{C}$ fueron usados para estimar los contenidos de $\mathrm{C}$ derivados del bosque (Cdf) y de pasto (Cdp) en todas las parcelas. Se calcularon las correlaciones entre estos contenidos y las características biofísicas del sitio y del suelo para identificar los mecanismos de estabilización de $\mathrm{C}$ en el suelo. Los resultados mostraron que la estabilización de $\mathrm{C}$ a largo plazo en Andisoles es explicada por la formación de complejos de metal-humus y alófana, mientras que en Inceptisoles la estabilización de $\mathrm{C}$ a largo plazo esta determinada por la absorción del humus con los minerales de arcilla. Se encontró evidencia que el carbono recientemente incorporado no se estabilizó en Andisoles, mientras en Inceptisoles los pobremente cristalinos (hidr -) óxidos parecen haber estabilizado parte de este $\mathrm{C}$ en el suelo. Yo concluyo que a menos que los mecanismos de estabilización de $\mathrm{C}$ en el suelo sean explícitamente considerados, no se podrá predecir la dirección y magnitud de los cambios de los contenidos de $\mathrm{C}$ en el suelo después de conversión de un uso en otro en las regiones tropicales.

(2) La influencia de las características del suelo y paisaje en la diversidad de las plantas:

Aunque está claro que las características del suelo y la natural diversidad de las plantas están íntimamente relacionadas, muchas de las relaciones entre las propiedades especificas del suelo con los componentes de diversidad de las plantas, siguen siendo poco estudiado y a menudo contradictorio, especialmente en los ecosistemas disturbados por el hombre. En este estudio se investiga la influencia de un rango de propiedades del suelo y su heterogeneidad en la beta y gama diversidad en tres sistemas de uso del suelo y en dos posiciones del paisaje en una fragmentada región tropical de la costa central del Ecuador. Los sistemas de uso del suelo estudiados fueron, en orden creciente de intensidad de interferencia humana, sistemas agroforestales de café, pastos y arroz. En todos los sistemas de uso del suelo, la beta diversidad comprendió la mayor parte de la diversidad total de especies de hierbas, con la más alta relativa beta diversidad en los sistemas agroforestales de café, aunque este tipo de uso tuvo una más baja riqueza total de especies. Yo demuestro que en todos los sistemas de uso del suelo, la diversidad de hierbas fue positivamente correlacionada con la heterogeneidad de varias propiedades del suelo. La heterogeneidad del suelo (expresada como el coeficiente de variación de las propiedades dentro de parcela) fue un buen preeditor de la diversidad de hierbas que los valores de las propiedades del suelo por si mismas. Con modelos de regresión lineal, se mostró que para todos los tipos de 
uso del suelo combinados, el $40 \%$ de la diversidad gama puede ser explicada con los factores fijos: uso del suelo y posición en el paisaje, en combinación con la heterogeneidad del suelo (específicamente la heterogeneidad de magnesio). Mientras que cuando analizamos los usos del suelo separadamente, un $80 \%$ de la diversidad gama en sistemas agroforestales de café puede ser explicada por posición en el paisaje y heterogeneidad de magnesio. Aunque para pasto y arroz bajos porcentajes de diversidad de hierbas puede ser explicado (32\%), pero la heterogeneidad del suelo fue todavía un preeditor significante. La posición del paisaje se expresó por una más alta diversidad de hierbas en suelos localizados en las partes altas que en los suelos de partes bajas, probablemente como resultado de problemas de drenaje en las áreas bajas. Este estudio muestra que la heterogeneidad de los suelos- y paisaje contribuyen a la diversidad de las plantas y por consiguiente son aspectos importantes que se deben considerar al planificar medidas de conservación.

3) El efecto de erosión y sedimentación en la redistribución del carbono orgánico del suelo: Los cambios de uso del suelo pueden incrementar la erosión del suelo y por consiguiente las pérdidas de nutrientes y los contenidos de carbono orgánico del suelo. Muchos estudios de erosión han considerado las pérdidas del suelo sin tomar en cuenta los procesos de sedimentación o deposición. En este capítulo, yo evalúo cómo los procesos de erosión y sedimentación del suelo afectan al balance de $\mathrm{C}$ en una cuenca geográfica al oeste del Ecuador. Usando un balance de masa aproximado, yo calculo primero la cantidad de suelo perdido y ganado causado por los procesos de erosión, transporte y deposición bajo el presente uso del suelo. Luego se analizó cual seria el efecto de diferentes escenarios de cambio de uso del suelo comparado con la situación presente. Yo encontré que en suelos con textura arenosa, los cambios de uso del suelo no afectaron el balance de $\mathrm{C}$ a nivel de cuenca, mientras que en suelos de textura arcillosa y franca y especialmente en terrazas fluviales, los cambios en el uso del suelo tienen mayor impacto en la redistribución de C del suelo. La conversión de los sistemas agroforestales a arroz de secano (un sistema de uso de la tierra en que el suelo permanece descubierto por algún periodo de tiempo) lleva a altas perdidas de $\mathrm{C}$ del suelo de la cuenca, mientras que lo opuesto ocurre si los campos de arroz fueran convertidos a sistemas agroforestales. Este estudio mostró que la redistribución de $\mathrm{C}$ del suelo por procesos de erosión y sedimentación fuertemente depende del cambio de uso del suelo y del material parental. 
Los resultados de esta tesis pueden ser usados como base para el desarrollo de modelos que evalúan los efectos de diferentes escenarios de cambio de uso de la tierra en los servicios ambientales del suelo. Aunque algunos servicios ambientales del suelo fueron discutidos, es necesario incluir otros servicios ambientales tales como conservación del agua. Los servicios del suelo son altamente interdependientes, así que una meta futura debe ser la investigación de trade-offs entre los diferentes servicios como resultado de los cambios de uso de tierra. En semejante análisis es crítico evitar pérdidas irreversibles de algunos de estos servicios y al mismo tiempo identificar cambios de uso de la tierra que lleven a una situación de ("ganancia-ganancia"). En conclusión, estos diferentes estudios muestran que es posible hacer una investigación cuantitativa de las funciones del suelo que van más allá de la tradicional aproximación de "caja negra". Además, la información biofísica del suelo que se generó en esta tesis ayudará a optimizar los escenarios de cambios de uso. Tales escenarios pueden ayudar a los tomadores de decisión a desarrollar estrategias para conservación y practicas sustentables de uso de la tierra. 


\section{References}

Aide, M. T., Zimmerman, J.K., Herrera, L., Rosario, M., Serrano, M. (1995): Forest recovery in abandoned tropical pastures in Puerto Rico. Forest Ecology and Management, 77: 77-86.

Albrecht, H. (1995): Changes in the arable weed flora of Germany during the last five decades. In: proceedings of the Ninth European weed Research Society Symposium on Challenges for Weed Science in a Changing Europe, Budapest, pp. 41-48.

Albrecht, H. (2003): Suitability of arable weeds as indicator organisms to evaluate species conservation effects of management in agricultural ecosystems agriculture. Agriculture, Ecosystems and Environment 98: 201-211.

Altieri, M.A. (1999): The ecological role of biodiversity in agroecosystems. Agriculture, Ecosystems and Environment 74: 19-31.

Ambassa-Kiki, R., and Nill, D. (1999): Effects of different land management techniques on selected topsoil properties of a forest Ferrasol. Soil and Tillage Research 52: 259-264.

Amundson, R. (2001): The Carbon Budget in Soil. Annual Review, Earth Planet. Science 29:535-562.

Ashton, P. (1992): Species richness in plant communities. Conservation Biology, pp. 3-22. London: Chapman and Hall.

Balesdent, J., Mariotti, A., Guillet, B. (1987): Natural ${ }^{13} \mathrm{C}$ abundance as a tracer for studies of soil organic matter dynamics. Soil Biology Biochemestry. 19:25-30.

Balesdent, J., Wagner, G.H., Mariotti, A. (1988): Soil organic matter turnover in long-term field experiment as reveleaded by carbon-13 natural abundance. Soil Science Society American Journal 52:118-124. 
Balesdent, J., and Mariotti, A. (1996): Measurement of Soil Organic Matter Turnover using ${ }^{13} \mathrm{C}$ Natural Abundances. p. 83-111. In Boutton, T.W., and S. I. Yamasaki (ed.) Mass Spectrometry of Soils. Marcel Dekker Inc., New York.

Bashkin, M.A., and Binkley, D. (1998): Changes in soil carbon following afforestation in Hawaii. Ecology. 79:3, 828-833.

Bengtsson, J. and Ahnström, P. (2005): The effects of organic agriculture on biodiversity and abundance a meta analysis. Journal of Applied Ecology 42: 261-269.

Benitez, P.C., Kuosmanen, T., Olschewski, R., van Kooten, G.C. (2006): Conservation payments under risk: A Stochastic Dominance Approach. American Journal Agronomic Economic 88: 1-15.

Benton, T.G., Vickery, J. A., Wilson, J.D. (2003): Farmland biodiversity: is habitat heterogeneity the key?. Trends in Ecology and Evolution 18: 182-188.

Bergstrom, D.W., Monreal, C.M., St Jacques, E. (2001): Spatial dependence of soil organic carbon mass and its relationship to soil series and topography. Canadian Journal of Soil Science 81: 53-62.

Berish, C.W., and Ewel, J.J. (1988): Root development in simple and complex tropical successional ecosystems. Plant Soil 106:73-84.

Beyer, L., Fruid, R., Schleuss, U., Wachendorf, C. (1993): Colluvisols under cultivation in Scheleswig-Holstein. 2. Carbon distribution and soil organic matter composition. Journal of Plant Nutrition and Soil Science 156: 213-217.

Binning, C., Cork; S., Parry, R., Shelton, D. (2001): "Natural assets: An inventory of ecosystems goods and services in the Goulburn Broken catchment". Commonwealth Scientific and Industrial Research Organization, Canberra Australia. 
Boudot, J.P. (1992): Relative efficiency of complexed aluminium, noncrystalline Al hidroxide, alloplane and imogolite in retarding the biodegradation of citric acid. Geoderma 52:29-29.

Brown, S., and Lugo, A.E. (1990): Effects of forest clearing and succession on the carbon and nitrogen content of soils in Puerto Rico and US Virgin Islands. Plant Soil 124:5364.

Cerda, A. (1999): Parent material and vegetation affect soil erosion in Eastern Spain. Soil Science American Journal 63: 362-368.

Chaplot, V., Bernoux, M., Walter, C., Curmi, P., Herpin, U. (2001): Soil carbon storage prediction in temperate hydromorphic soils using a morphologic index and digital elevation model. Soil Science 166: 48-59.

Christensen, B.T. (1996): Carbon in primary and secondary organic mineral complexes. p. 97-165. In: Carter M.R. and B.A. Stewart BA (ed.) Structure and Organic Matter Storage in Agricultural Soils. CRC Press, Boca Raton, FL.

Claessens, L., Heuvelink, G. B. M., Schoorl J.M., and Veldkamp, A. (2005): DEM resolution effects on shallow landslide hazard and soil redistribution modelling. Earth Surface Processes and Landforms 30: 461-477.

Clark, D.B., Clark, D.A., Read, J.M. (1998): Edaphic variation and the mesoscale distribution of tree species in a neotropical rain forest. Journal of Ecology 86: 101-112.

Clinebell, R.R., Phillips, H.O.L., Gentry, A.H., Stark, N., Zuurring, H. (1995): Predictions of neotropical tree and liana species richness from soil and climatic data. Biodiversity and Conservation 4: 59-90.

Costanza, R., d'Arge, R., de Groot, R., Farber, S., Grasso, M. (1997): The value of the world's service and natural capital. Nature 387: 253-260. 
Daily, G.C. (1999): Developing a scientific basis for managing earth's life support systems. Conservation Ecology 3: 1-15.

Daily, G.C. et al. (2000): Ecology - The value of nature and the nature of value. Science 289: 395-396.

Daily, G.C., Alexander, S., Ehrlich, P.R., Goulder, L., Lubchenco, J., Matson, P.A., Mooney, H.A., Postel, S., Schneider, S.H., Tilman, D., Woodwell, G.M. (1997): Ecosystem services: benefits supplied to human societies by natural ecosystems. Issues in Ecology 2: 1-16.

Davidson, E.A., and Ackerman, I.L. (1993): Changes in soil carbon inventories following cultivation of previously untilled soils. Biogeochemistry 20(3): 161-193.

de Groot, R.S., Wilson, M. A., Boumans, R. M. J. (2002): A typology for the classification, description and valuation of ecosystem functions, goods and services. Ecological Economics 41: 393-408.

de Koning, G.H.J., Veldkamp, E., Lopez-Ulloa, M. (2003): Quantification of carbon sequestration in soils following pasture to forest conversion in northwestern Ecuador, Global Biogeochemical Cycles, 17(4): 1056- 1067

Detwiller, R.P. (1986): Land use change and the global carbon cycle: the role of tropical soils. Biogeochemistry 2:67-93.

Diamond, J. (1988): Factors controlling species diversity: overview and synthesis. Annals of the Missouri Botanical Garden 75: 117-129.

Duivenvoorden, J. F. (1994): Vascular plant species counts in the rain forests of the middle Caquetá area, Colombian Amazonia. Biodiversity and Conservation 3: 685-715.

Duivenvoorden, J.F., and Lips, J.M. (1995): A land-ecological study of soils, vegetation, and plant diversity in Colombian Amazonia. Tropenbos Series 12. Tropenbos, Wageningen, The Netherlands. 
Duque, A., Sánchez, M., Cavaleir, M., Duivenvoorden, J.F. (2002): Different florist patterns of woody understorey and Canopy plants in Colombian Amazonia. Journal of Tropical ecology 18: 499-525.

El-Ghani, M.M.A. and Amer, W.A. (2003): Soil-vegetation relationships in a coastal desert plain of southern Sinai, Egypt. Journal of Arid Environments 55: 607-628.

Fang, H.J., Cheng, S.L., Zhang, X.O., Liang, A.Z., Yang, X.M., Drury, C.F. (2006): Impact of soil redistribution in a sloping landscape on carbon sequestration in northeast China. Land Degradation \& Development 17: 89-96.

Fearnside, P.M. (1997a): Environmental services as a strategy for sustainable development in Rural Amazonia. Ecology Economy 20:53-40

Fitter, A. H. (1982): Influence of soil heterogeneity on the coexistence of grassland species. Journal Ecology 70: 139-148.

Fölster, H., Dezzeo, N., Priess, J.A. (2001): Soil-vegetation relationship in base- deficient premontane moist forest- savanna mosaics of the Venezuelan Guayana. Geoderma 104: 95-113.

Francis, C.F., and Thornes, J.B. (1990): Runoff hydrographs from three Mediterranean vegetation cover types. In: Thornes, J. B., editor. Vegetation and Erosion, Processes and Environments. Wiley, Chichester 363-384.

Gabriel, D., Roschewitz, I., Tsscharntke, T., Thies, C. (2006): Relative importance of beta diversity at different spatial scales-plant communities in organic and conventional agriculture. Journal of Applied Ecology, In press.

Gentry, A. H. (1988): Changes in plant community diversity and floristic composition on geographical and environmental gradients. Annals of the Missouri Botanical Garden 75: $1-34$. 
Gentry, A. H. and Emmons, L. H. (1987): Geographical variation in fertility, phenologhy, and composition of the understory of Neotropical forests. Biotropica 19: 216-227.

Gibson, D. J. (1988): The maintenance of plant and soil heterogeneity in dune grassland. Journal of Ecology 76: 497-508.

Gregorich, E.G. and Ellert, B.H. (1993): Soil Sampling and Methods of Analysis. Canadian Society Soil Science 39:397-401.

Guo, L.B., and Gifford, R.M. (2002): Soil carbon stocks and land use change: a meta analysis. Global Change Biology 8: 345-60.

Hassink, J. (1997): The capacity of soils to preserve organic C and $\mathrm{N}$ by their association with clay and silt particles. Plant Soil 191:77-87.

Heinrichs, H. (1989): Aufschlussverfahren in der analytische Geochemie (1). Labor Praxis 12: $1140-1146$.

Hole, D.G., Perkins, A.J., Wilson, J.D., Alexander, I.H, Grice, P.V., Evans, A.D. (2005): Does organic farming benefits biodiversity? Biological Conservation 122: 113-130.

Hope, D., Billet, M.F., Cresser, M.S. (1994): A review of the export of carbon in river water: Fluxes and processes. Environmental Pollution 84: 301-324.

Hughes, J.B., Daily, G.C., Ehrlich, P.R. (1997): Population diversity: Its extent and extinction. Science 278: 689-692.

Huston, M. (1980): Soil nutrients and tree species richness in Costa Rican forests. Journal of Biogeography 7: 147-157.

Huston, M.A. (1999): Local processes and regional patterns: appropriate scales for understanding variation in the diversity of plants and animals. Oikos 86: 393-401. 
INAMHI (2002): Instituto Nacional de Meteorología e Hidrología. Anuarios Meteorológicos (1995-2002). Quito, Ecuador.

I

INEC, MAG and SICA, (2001): "II Censo Nacional Agropecuario: Resultados Provinciales y Cantonales - Manabi”. Quito: Instituto Ecuatoriano de Estadísticas y Censos.

IPCC, (1996): Revised IPCC Guidelines for National Greenhouse Gas Inventories: Reference manual. Volume 3. Intergovernmental panel on Climate Change. Cambridge University Press: Cambridge.

Jacinthe, P.A., Lal, R., Kimble, J. (2001): Assessing water erosion impacts on soil carbon pools and fluxes. In Assessment Methods for Soil carbon Pools. Lal, R., Kimble, J.M., Follett, R.F., Stewart, B.A. editors. Boca Raton: CRC/Lewis Publishers 427-450.

Jackson R.B., Banner J.L., Jobbágy E.G., Pockman W.T., Walls D.H. (2002): Ecosystem carbon loss with woody plant invasion of grasslands. Nature 418: 623-626.

Janzen, H.H., Campbell, C.A., Izaurralde, R.C., Ellert, B.H., Juma, N., McGill, W.B., Zentner, R.P., (1998): Management effects on soil C storage on the Canadian prairies. Soil \& Tillage 47: 181-195.

Jenny, H. (1941): Factors of soil formation. A system of quantitative pedology. McGrawHill, New York,

Jobbagy, E.G. and Jackson, R.B. (2000). The vertical distribution of soil organic carbon and its relation to climate and vegetation. Ecological Applications 10(2):423-436.

Kahmen, A., Perner, J., Audorff, V., Weisser, W., Buchmann, N. (2005): Effects of plant diversity, community composition and environmental parameters on productivity in montane European grasslands. Oecologia 142: 606-615. 
Kahn, F. and de Castro, A. (1995): The palm community in a forest of Central Amazonia, Brazil. Biotropica 17: 210-216.

Kassen, R., Buckling, A., Bell, G., Rainey, P.B. (2000): Diversity peaks at intermediate productivity in a laboratory microcosm. Nature 406: 508-512.

Kearns, C.A., Inouye, D.W., Waser, N.M. (1998): Endangered mutualisms: the conservation of plant-pollinator interactions. Annual Review of Ecology and Systematic 29: 83-112.

Kneitel, J. M. and Miller, T.E. (2003): Dispersal rates affect species composition in meta communities of Sarracenia-purpurea inquiles. American Nature 162: 165-171.

Kok, M., and Michel, R. unpublished soil and map report (2004): Soils and Land Evaluation using the desag (C) method for the Noboa and Pajan area, Manabi province, Ecuador. Noboa- Pajan Soil Report. Wageningen-Goettingen University. Pp. 100.

König, N. and Fortmann, H. (1996): Probenvorbereitungs-, Untersuchungs- und Elementbestimmungs-Methoden des Umweltanalytik-Labors der Niedersächsischen Forstlichen Versuchsanstalt, 1-4, Berichte des Forschungszentrums Waldökosysteme, Reihe B, University of Göttingen, Germany, B46-B49, ISSN 0939-1339.

Kosmas, C., Gerontidis, St., Marathianou, M. (2000): The effect of land use change on soils and vegetation over various lithological formations on Lesvos (Greece). Catena 40: $51-68$.

Lal, R., (1995): Global soil erosion by water and carbon dynamics. In: Lal R., J.M. Kimble, E. Levine, B.A. Stewart, editors. In Soils and global change. Boca Raton: CRC/Lewis Publishers 131-141.

Lal, R. (2003): Soil erosion and the global carbon budget. Environment International 29: 437-450. 
Lal, R., Kimble, J.M., Follet, R.F., Stewart, B.A. editors, (1998a): Soil processes and the carbon cycle. Boca Raton: CRC/Lewis Publishers 609 pp.

Lal, R., Kimble, J.M., Follet, R.F., Stewart, B.A. editors, (1998b): Management of carbon sequestration in soils. Boca Raton: CRC/Lewis Publishers 609 pp.

Lambin, E.F., Turner, B.L., Geist, H.J., Agbola, S.B., Angelsen, A., Bruce, J.W., Coomes, O.T., Dirzo, R., Fischer, G., Folke, C., George, P.S., Homewood, K., Imbernon, J., Leemans, R., Li, X., Moran, E.F., Mortimore, M., Ramakrishnan, P.S., Richrads, J.F., Skanes, H., Steffen, W., Stone, G.D., Svedin, U., Veldkamp, T.A., Vogel, C., XU, J. (2001): The cause of Land-use and land-cover change: moving beyong the myths. Global Environmental Change. 11: 261-269.

Lande, R. (1996): Statistics and partitioning of species diversity, and similarity among multiple communities. Oikos 76: 5-13.

Lawton, J.H., Bignell, D.E., Bolton, B., Bloemers, G. F., Larsen, P., Mawdsley, N. A, Stork, N.E., Srivastava, D.S., Watt, A.D. (1998): Biodiversity inventories, indicator taxa and effects of habitat modification in tropical forest. Nature 391: 72-76.

Lee, C.R., and Skogerboe, J.G. (1985): Quantification of erosion control by vegetation on problem soils. In: Swaify, A.L., W.C. Moldenhauer, A. Lo, editors. Soil Erosion and Conservation. Soil Conservation Society of America 437-444.

López, M., de Koning, G.H.J., Paredes, H., Benitez, P. (2002): Estimación de carbono en biomasa de bosques secundarios y plantaciones forestales en el noroccidente de Ecuador. Report TWF-31s, Tropical Ecology Support Program (TOEB) of the German Technical Cooperation (GTZ). Eschborn, Germany.

López-Ulloa, M., Veldkamp, E., de Koning, G.H.J. (2005): Soil carbon stabilization in converted tropical pastures and forests depends on soil type. Soil Science Society of America Journal 69: 1110-1117. 
Ludwing, W., Amiotte-Suchet, P., Probst, J.L. (1996): River discharge of carbon to the world's oceans: Determining local inputs of alkalinity and of dissolved and particulate organic carbon. Comptes Rendus de l'Académie des Sciences, Série II, Sciences de la terre et des Planétes 323: 1007-1014.

Lui, S., Bliss, N., Sundquist, E., Huntigton, T.G. (2003): Modeling carbon dynamics in vegetation and soil under the impact of soil erosion and deposition. Global Biochemical Cycles 17: 1074-1098.

McKane, R.B., Johnson, L.C., Shaver, G.R., Nadelhoffer, K.J., E.B. Rastetter, E.B., Fry, B., Giblin, A.E., Kielland, K., Kwiatkowski, B.L., Laundre, J.A., Murray, G. (2002): Resources-based niches provide a basis for plant species diversity and dominance in artic tundra. Nature 415:68-71.

Melillo, J.M., Houghton, R.A., Kicklighter, D.W., McGuire, A.D. (1996): Tropical deforestation and the global carbon budget. Annual Review, Energy Environment 21:293-310.

Mizota, C., and van Reeuwijk, L.P. (1989): Clay mineralogy and chemistry of soils formed in volcanic material in diverse climatic regions. ISRIC, Wageningen.

Mutuo, P. K., Cadisch, G., Albrecht, A., Palm, C.A., Verchot, L. (2005): Potencial of agroforestry for carbon sequestration and mitigation of greenhouse gas emissions from soils in the tropics. Nutrient cycling in Agroecosystems 71: 43-54.

Myers, N., Mittermeier, R.A., Mittermeier, C.G., da Fonseca, G.A.B., Kent, J. (2000): Biodiversity hotspots for conservation priorities. Nature 403: 853-858.

Neill, C., Fry, B., Melillo, J.M., Steudler, P.A., Moraes, J.F.L., Cerri, C.C. (1996): Forestand pasture- derived carbon contribution to carbon stocks and microbial respiration of tropical pasture soils. Oecologia 107(1):113-119.

Oades, J.M. (1988): The retention of organic matter in soils. Biogeochesmistry 5:35-70. 
Oldeman, L., van Engelen, V., Pulles, J. (1990): "The extent of human-induced soil degradation", Annex 5. of L.R. Oldeman, R.T.A. Hakkeling, W.G. Sombroek, World Map of the Status of Human-induced soil degradation: An Explanatory Note, rev. 2d ed. Wageningen: International soil Reference and Information Centre.

Oliveira-Filho, A.T., Vilela, E.A., Carvalho, D.A., Gavilanes, M.L. (1994): Effects of soils and topography on the Distribution of tree species in a tropical riverine forest in south-eastern Brazil. Journal of tropical Ecology 10: 483-508.

Osher, L.J., Matson, P.A., Amundson, R. (2003): Effect of land use change on soil carbon in Hawaii. Biogeochemestry 65:213-232.

Paul, K.I., Polglase, P.J., Nyakuengama, J.G., Khanna, P.K. (2002): Change in soil carbon following afforestation. Forest Ecology Manage 168: 241-257.

Pennock, D.J., and van Kessel, C. (1997): Effect of agriculture and of clear-cut forest harvest on landscape-scale, soil organic carbon storage in Saskatchewan. Canadian Journal of Soil Science 77: 211-218.

Pennock, D.J., Anderson, D.W., de Jong, E. (1994): Landscape-scale changes in indicators of soil quality due to cultivation in Saskatchewan, Canada. Geoderma 64: 1-19.

Percival, H.J., Parfitt, R.L., Scott, N.A. (2000): Factors Controlling Soil Carbon Levels in New Zealand Grasslands: Is Clay Content Important?. Soil Science Society American Journal 64:1623-1630.

Poulsen, A. D. (1996): Species richness and density of ground herbs within a plot of lowland rainforest in North-West Borneo. Journal of Tropical Ecology 12: 177-190.

Poulsen, A. D. and Balslev, H. (1991): Abundance and cover of ground herbs in an Amazonian rain forest. Journal of Vegetation Science 2: 315-322. 
Powers, J.S. (2001): Geographic variation in soil organic carbon dynamics following landuse change in Costa Rica. PhD Thesis, Duke University, Durham.

Powers, J.S., and Schlesinger, W.H. (2002): Relationships among soil carbon distributions and biophysical factors at nested spatial scales in rain forests of northeastern Costa Rica. Geoderma 109:165-190.

Powers, J.S., and Veldkamp, E. (2005): Regional variation in soil carbon and delta C-13 in forests and pastures of northeastern Costa Rica. Biogeochemistry 72(3): 315-336.

Pysek, P. and Leps, J. (1991): Response of a weed community to nitrogen-fertilization-a multivariate-analysis. Journal of Vegetation Science 2: 237-244.

Quin, P., Beven, K., Chevallier, P., Planchon, O. (1991): The prediction of hillslope flow paths for distributed hydrological modeling using digital terrain models. Hydrological Processes 5: 59-79.

Rhoades, C.C., Eckert, G.E., Coleman, D.C. (2000): Soil Carbon Differences among Forest Agriculture, and Secondary Vegetation in lower Montane Ecuador. Ecological Applications 10:497-505.

Robertson, G.P. and Swinton S.M. (2005): Reconciling agricultural productivity and environmental integrity: a grand challenge for agriculture. Frontiers in Ecology and the Environment 3: 38-46.

Rosenzweig, M.L. (1995): Species Diversity in Space and Time. Cambridge University Press, Cambridge, Great Britain.

Schneider, S.H., Tilman, D., Woodwell, G.M. (1997): Ecosystem services: benefits supplied to human societies by natural ecosystems. Issues in Ecology 2: 1-16. 
Schoorl, J.M. and Veldkamp, A. (2001): Linking land use and landscape process modelling: a case study for the Álora region (south Spain). Agriculture, ecosystems and Environment 85: 281-292.

Schoorl, J.M., Veldkamp, A., and Bouma, J. (2002): Modeling water and soil redistribution in a Dynamic Landscape context. Soil Science American Journal. 66: 1610-1619.

Schoorl, J.M., Claessens, L., Lopez-Ulloa, M., de Koning, F.G.H., Veldkamp, A. (2006): Geomorphological Analysis and Scenario Modelling in the Noboa-Pajan Area, manabi Province, Ecuador. Zeitschrift Fur Geomorfologie, In press

Segarra, P., unpublished land use map (2004): Mapa del uso del suelo para la región sur de Manabi. Proyecto Bio-sys.

Shoji, S., Nanzyo, M., Dahlgren, R. (1993): Volcanic ash soils: genesis, properties and utilization. Developments in Soil Science. Elsevier, Amsterdam, The Netherlands.

Sierra, R. (1999): Propuesta preliminar de un sistema de clasificación de vegetación para el Ecuador Continental., Proyecto INEFAN/GEF, Ecociencia. Quito-Ecuador, pp. 50.

Six, J., Conant, R.T., Paul, E.A., Paustian, K. (2002): Stabilization mechanisms of soil organic matter: Implications for C-saturation of soil. Plant Soil 241:155-176.

Sollins, P., Homann, P., Caldwell, B.A. (1996): Stabilisation and destabilisation of soil organic matter: mechanisms and control. Geoderma 74:65-105.

Stallard, R.F. (1998): Terrestrial sedimentation and the carbon cycle: Coupling weathering and erosion to carbon burial. Global Biogeochemical Cycles 12: 231-257.

StatSoft, Inc. (2003): STATISTICA (data análisis software system), version 6. www.statsoft.com. 
Stoate, C., Boatman, N.D.; Borralho, R.J., Rio Carvalho, C., de Snoo, G.R., Eden, P. (2001): Ecological impacts of arable intensification in Europe. Journal of Environmental Management 63: 337-365.

Swanson, F. J., Kratz, T.K., Caine, N., Woodmansee, R.G. (1988): Land-form effects on ecosystem patterns and processes. BioScience 38: 93-98.

Swift, R.S. (2001): Sequestration of carbon by soil. Soil Science 166:858-871.

Tilman, D. (1988): Plant strategies and the dynamics and structure of plant communities. Princeton University Press, Princeton, NJ.

Tilman, D., Fargione, J., Wolff, B., D'Antonio, C., Dobson, A., Howarth, R., Schindler, D., Schlesinger, W.H., Simberloff, D., Swackhamer, D. (2001): Forecasting agriculturally driven global environmental change. Science 292: 281-284.

Torn, M.S., Trumbore, S.E., Chadwick, O.A., Vitousek, P.M., Hendricks, D.M. (1997): Mineral control of soil organic carbon storage and turnover. Nature 389:170-173.

Trumbore, S.E., Davidson, E.A., Camargo, P.B., Nepstad, D.C., Matinelli, L.A. (1995): Belowground cycling of carbon in forests and pastures of eastern Amazonia. Global Biogeochemical Cycles 9:515-528.

Tuomisto, H. and Ruokolainen, K. (1994): Distribution of Pteridophyta and Melastomataceae along and edaphic gradient in an Amazonian rain forest. Journal of Vegetation Science 5: 25-34.

Tuomisto, H. and Ruokolainen, K. (2002): Distribution and diversity of Pteridophytes and Melastomataceae along edaphic gradients in Yasuní National Park. Biotropica 34: 516533.

Tuomisto, H., Poulsen, A.D., Morgan, R.C. (1998): Edaphic distribution of some species of the fern genus Adiantum in Western Amazonia. Biotropica 30: 392-399. 
Tuomisto, H., Ruokolainen, K., Moran, R.C., Quintana, C., Celi, J., Cañas, G. (2003): Linking floristic patterns with soil heterogeneity and satellite imagery in Ecuadorian Amazonia. Ecological Applications 13: 352-371.

Turner, R.K., Dent, D., Hey, R. (1998): Ecosystem services value, research needs and policy relevance: a commentary. Ecological Economics 25: 61-65.

Tylianakis, J.M., Klein, A.-M., Tscharntke, T. (2005): Spatiotemporal variation in the effects of a tropical habitat gradient on Hymenoptera diversity. Ecology 86: 3296-3302.

van Elsen, T., (2000): Species diversity as a task for organic agriculture in Europe. Agriculture, Ecosystems and Environment 77: 101-109.

van Noordwijk M., Cerri, C., Woomer, P.L., Nugroho K., and Bernoux, M. (1997): soil carbon dynamics in the humid tropical forest zone. Geoderma 79: 187-225.

Veldkamp, E. (1994): Organic carbon turnover in three tropical soils under pasture after deforestation. Soil Science Society American Journal 58:175-180.

Whitney, G. G. (1991) Relation of plant species to substrate, landscape position, and aspect in north central Massachusetts. Canadian Journal of Forest Research 21: 1245-1252.

Wijesinghe, D.K., John, E.A., Hutchings, M.J. (2005): Does pattern of soil resource heterogeneity determine plant community structure? An experimental investigation. Journal of Ecology 93: 99-112.

Wilson, S.D. (1992): Complex interactions in meta communities with implications for biodiversity and higher levels of selection. Ecology, 73:1984-2000.

Wilson, S.D. (1997): Competition between grasses and woody plants. In G. Cheplick, (ed. Population biology of grasses). Cambridge University Press, Cambridge. 
Wilson, S.D. (2000): Heterogeneity, diversity and scale in plant communities. (eds M. J. John, E.A. and Stwart, A.J.A - In: Hutchings), pp.53-69. The ecological consequences of environmental heterogeneity. Blackwell.

World Resources Institute (2000): “A guide to world resources 2000-2001". World Resources Institute, Washington D.C.

Yoo, K., Amundson, R., Heimsath, A.M., Dietrich, W.E. (2005): Erosion of upland hillslope soil organic carbon: Coupling field measurements with a sediment transport model. Global Biogeochemical Cycles 19(3).

Zinn, Y.L., Resck, D.V.S., da Silva, J.E. (2002): soil organic carbon as affected by afforestation with Eucaltptus and Pinus in the Cerrado region of brazil. Forest ecology managment 166: 285-294. 


\section{8}

\section{Appendix}

Appendix 2.1: General database for chapter 2

\begin{tabular}{|c|c|c|c|c|c|c|}
\hline ID & Description & X (UTM 17 E) & Y (UTM 17 N) & Soil type & Precipitation (mm/yr) & Altitude (m) \\
\hline 1 & Arenales & 715150 & 10093345 & $\mathrm{~S}$ & 2938 & 21 \\
\hline 2 & Santo Domingo & 714541 & 10088067 & S & 2869 & 48 \\
\hline 3 & San Lorenzo & 741182 & 10140931 & S & 2625 & 29 \\
\hline 4 & Mindo Lindo & 748550 & 9997777 & $\mathrm{~V}$ & 3459 & 1649 \\
\hline 5 & Mindo & 747839 & 9992760 & $\mathrm{~V}$ & 3485 & 1410 \\
\hline 6 & La Mayronga & 698313 & 10098703 & $\mathrm{~S}$ & 2000 & 96 \\
\hline 7 & Rio Silanche & 719601 & 10011002 & V & 4860 & 600 \\
\hline 8 & Nuevo Mundo & 726500 & 9991050 & V & 4038 & 850 \\
\hline 9 & Maquipucuna & 762255 & 10013329 & V & 2310 & 1251 \\
\hline 10 & Rio Castillo & 698101 & 10046390 & V & 2798 & 198 \\
\hline 11 & Las Golondrinas & 695998 & 10033540 & $\mathrm{~V}$ & 3030 & 204 \\
\hline 12 & San Mateo & 653273 & 10094685 & S & 1170 & 20 \\
\hline 13 & Rio Esmeraldas & 653383 & 10099965 & S & 978 & 15 \\
\hline 14 & Chaupara & 665943 & 10045920 & $\mathrm{~S}$ & 2383 & 140 \\
\hline 15 & Río Blanco & 685208 & 10013991 & V & 3150 & 166 \\
\hline 16 & Chontaduro & 675267 & 10102149 & S & 1823 & 56 \\
\hline 17 & Las Minas & 659524 & 10094599 & S & 1327 & 147 \\
\hline 18 & Guadualito & 757781 & 10136083 & S & 3157 & 132 \\
\hline 19 & La Chiquita & 748087 & 10137429 & S & 2808 & 67 \\
\hline 20 & La Union & 681157 & 10014117 & V & 3080 & 170 \\
\hline 21 & Puerto Quito & 693961 & 10011124 & V & 3402 & 281 \\
\hline 22 & Salima & 633292 & 10088869 & $\mathrm{~S}$ & 1401 & 54 \\
\hline 23 & Tazones & 628669 & 10082515 & $\mathrm{~S}$ & 1762 & 46 \\
\hline 24 & Muisne & 616319 & 10058427 & S & 2496 & 17 \\
\hline 25 & Sua & 623772 & 10090953 & $\mathrm{~S}$ & 1734 & 46 \\
\hline 26 & Guacharaco & 664081 & 10035499 & $\mathrm{~S}$ & 2421 & 136 \\
\hline 27 & Chaupara & 661606 & 10076351 & S & 1931 & 137 \\
\hline 28 & San Andres & 661411 & 10043814 & $\mathrm{~S}$ & 2370 & 116 \\
\hline 29 & Cube & 658868 & 10060763 & $\mathrm{~S}$ & 2021 & 221 \\
\hline 30 & Quinge & 600568 & 10079385 & S & 2561 & 76 \\
\hline 31 & Mache & 626200 & 10027096 & S & 2023 & 88 \\
\hline 32 & Chaflu & 656743 & 10081060 & S & 1705 & 147 \\
\hline 33 & Las Peñas & 707161 & 10118209 & $\mathrm{~S}$ & 2509 & 53 \\
\hline 34 & Patere & 721073 & 10110663 & S & 2683 & 27 \\
\hline 35 & Lagarto & 696672 & 10115995 & $\mathrm{~S}$ & 2356 & 32 \\
\hline 36 & La Concordia & 669941 & 10005606 & V & 3114 & 163 \\
\hline 37 & Pitzara & 704110 & 10029454 & V & 3467 & 294 \\
\hline 38 & San Francisco & 755813 & 10119631 & $\mathrm{~S}$ & 3730 & 68 \\
\hline 39 & Molinito & 712362 & 10126471 & $\mathrm{~S}$ & 2474 & 32 \\
\hline 40 & Alto Tambo & 771075 & 10105523 & $\mathrm{~S}$ & 2576 & 239 \\
\hline
\end{tabular}

soil origen: sedimentary $=S$; volcanic $=V$ 
Continuation appendix 2.1

\begin{tabular}{|c|c|c|c|c|c|c|c|c|c|c|c|c|}
\hline \multirow{2}{*}{$\begin{array}{l}\# \\
\text { ID }\end{array}$} & \multicolumn{6}{|c|}{ Pasture } & \multicolumn{6}{|c|}{ Forest } \\
\hline & Age (yr) & $\begin{array}{l}\text { Clay } \\
(\%)\end{array}$ & $\begin{array}{l}\text { Silt } \\
(\%)\end{array}$ & $\begin{array}{l}\text { Sand } \\
(\%)\end{array}$ & $\begin{array}{c}\mathrm{BD} \\
(\mathrm{g} / \mathrm{cm} 3)\end{array}$ & $\mathrm{C}(\%)$ & $\begin{array}{l}\text { Age } \\
(\mathrm{yr})\end{array}$ & $\begin{array}{l}\text { Clay } \\
(\%)\end{array}$ & $\begin{array}{l}\text { Silt } \\
(\%)\end{array}$ & $\begin{array}{c}\text { Sand } \\
(\%)\end{array}$ & $\begin{array}{c}\mathrm{BD} \\
(\mathrm{g} / \mathrm{cm} 3)\end{array}$ & $\mathrm{C}(\%)$ \\
\hline 1 & 15 & 27 & 60 & 13 & 0.77 & 2.94 & 15 & 32 & 62 & 6 & 0.82 & 3.12 \\
\hline 2 & 4 & 16 & 66 & 18 & 1.00 & 3.57 & 25 & 21 & 52 & 26 & 0.98 & 2.19 \\
\hline 3 & 9 & 27 & 60 & 13 & 1.13 & 2.16 & 25 & 21 & 66 & 13 & 1.16 & 2 \\
\hline 4 & 20 & 0 & 24 & 76 & 1.05 & 2.42 & 20 & 0 & 19 & 80 & 1.02 & 3.86 \\
\hline 5 & 20 & 2 & 21 & 77 & 1.04 & 3.69 & 20 & 1 & 24 & 75 & 0.80 & 5.21 \\
\hline 6 & 20 & 25 & 53 & 22 & 1.05 & 2.65 & 20 & 29 & 60 & 11 & 1.11 & 2.14 \\
\hline 7 & 13 & 0 & 49 & 51 & 0.73 & 4.99 & 21 & 2 & 55 & 44 & 0.71 & 4.65 \\
\hline 8 & 15 & 0 & 38 & 62 & 1.08 & 3.09 & 15 & 1 & 31 & 68 & 1.04 & 3.65 \\
\hline 9 & 3 & 6 & 37 & 57 & 1.04 & 3.08 & 15 & 5 & 42 & 53 & 1.17 & 3.96 \\
\hline 10 & 6 & 1 & 54 & 45 & 0.66 & 6.91 & 15 & 4 & 43 & 53 & 0.75 & 5.77 \\
\hline 11 & 20 & 3 & 47 & 50 & 0.74 & 5.18 & 17 & 2 & 50 & 48 & 0.62 & 6.02 \\
\hline 12 & 25 & 23 & 51 & 26 & 1.30 & 2.04 & 10 & 35 & 53 & 11 & 1.19 & 2.31 \\
\hline 13 & 25 & 38 & 60 & 2 & 1.07 & 1.92 & 18 & 31 & 55 & 14 & 1.16 & 2.02 \\
\hline 14 & 20 & 23 & 52 & 25 & 1.12 & 2.17 & 8 & 30 & 48 & 22 & 1.04 & 2.1 \\
\hline 15 & 30 & 0 & 12 & 88 & 1.30 & 2.34 & 11 & 0 & 11 & 89 & 1.14 & 2.48 \\
\hline 16 & 35 & 46 & 48 & 6 & 1.19 & 2.15 & 15 & 45 & 50 & 5 & 1.10 & 2.31 \\
\hline 17 & 32 & 60 & 38 & 3 & 0.97 & 2.62 & 14 & 55 & 41 & 4 & 0.98 & 3.17 \\
\hline 18 & 5 & 43 & 43 & 14 & 0.98 & 2.55 & 30 & 35 & 48 & 17 & 0.99 & 2.33 \\
\hline 19 & 5 & 17 & 64 & 20 & 1.34 & 1.62 & 25 & 35 & 49 & 16 & 1.09 & 2.08 \\
\hline 20 & 16 & 0 & 32 & 68 & 1.04 & 2.86 & 10 & 3 & 36 & 61 & 0.98 & 2.98 \\
\hline 21 & 7 & 0 & 50 & 50 & 0.64 & 4.9 & 11 & 6 & 48 & 46 & 0.67 & 4.14 \\
\hline 22 & 30 & 22 & 44 & 33 & 1.46 & 1.2 & 10 & 32 & 51 & 17 & 1.24 & 1.78 \\
\hline 23 & 30 & 29 & 48 & 23 & 1.27 & 1.34 & 11 & 28 & 46 & 26 & 1.19 & 1.55 \\
\hline 24 & 20 & 37 & 55 & 8 & 1.09 & 1.46 & 30 & 21 & 45 & 34 & 1.26 & 1.8 \\
\hline 25 & 45 & 33 & 46 & 22 & 1.26 & 2.62 & 15 & 43 & 46 & 11 & 0.96 & 4.18 \\
\hline 26 & 15 & 28 & 41 & 31 & 1.23 & 1.75 & 10 & 20 & 51 & 29 & 1.19 & 2.55 \\
\hline 27 & 10 & 61 & 34 & 6 & 0.84 & 2.82 & 15 & 46 & 48 & 6 & 0.74 & 3.59 \\
\hline 28 & 38 & 30 & 54 & 16 & 0.98 & 2.56 & 16 & 32 & 40 & 28 & 0.82 & 1.97 \\
\hline 29 & 20 & 28 & 56 & 16 & 1.06 & 1.93 & 15 & 32 & 56 & 12 & 0.99 & 2.6 \\
\hline 30 & 8 & 38 & 52 & 9 & 0.95 & 3.11 & 8 & 38 & 53 & 9 & 1.04 & 2.29 \\
\hline 31 & 2 & 28 & 54 & 18 & 1.02 & 2.1 & 8 & 31 & 54 & 15 & 1.00 & 2.06 \\
\hline 32 & 30 & 36 & 52 & 12 & 1.02 & 2.16 & 10 & 38 & 55 & 8 & 0.99 & 3.22 \\
\hline 33 & 25 & 36 & 36 & 27 & 1.32 & 1.85 & 17 & 36 & 44 & 20 & 1.18 & 2.54 \\
\hline 34 & 4 & 28 & 56 & 17 & 1.08 & 2.61 & 25 & 21 & 43 & 36 & 1.23 & 2.1 \\
\hline 35 & 35 & 40 & 39 & 21 & 1.14 & 2.75 & 20 & 38 & 45 & 17 & 0.84 & 3.78 \\
\hline 36 & 30 & 18 & 56 & 26 & 1.02 & 2.2 & 7 & 22 & 51 & 26 & 1.01 & 2.07 \\
\hline 37 & 20 & 5 & 54 & 41 & 0.65 & 5.69 & 10 & 3 & 52 & 45 & 0.61 & 6.5 \\
\hline 38 & 5 & 20 & 39 & 42 & 1.01 & 2.66 & 13 & 22 & 57 & 22 & 0.90 & 3.29 \\
\hline 39 & 24 & 8 & 17 & 76 & 1.16 & 1.62 & 7 & 9 & 4 & 88 & 1.31 & 1.88 \\
\hline 40 & 4 & 4 & 73 & 22 & 0.85 & 11.1 & 17 & 4 & 61 & 35 & 0.78 & 11.5 \\
\hline
\end{tabular}




\section{Continuation appendix 2.1}

\begin{tabular}{|c|c|c|c|c|c|c|}
\hline \multirow{2}{*}{$\begin{array}{l}\# \\
\text { ID }\end{array}$} & \multicolumn{6}{|c|}{ Pasture } \\
\hline & $\delta^{13} \mathrm{C}$ & $\mathrm{Al}_{\mathrm{o}}(\%)$ & $\mathrm{Fe}_{\mathrm{o}}(\%)$ & $\mathrm{Si}_{0}(\%)$ & $A l_{p}(\%)$ & $\mathrm{Fe}_{\mathrm{p}}(\%)$ \\
\hline 1 & -21.1 & 0.41 & 1.55 & 0.09 & 0.22 & 0.41 \\
\hline 2 & -25.7 & 0.42 & 1.03 & 0.07 & 0.22 & 0.37 \\
\hline 3 & -24.3 & 0.24 & 1.06 & 0.05 & 0.10 & 0.34 \\
\hline 4 & -23.7 & 0.76 & 1.64 & 0.19 & 0.40 & 0.20 \\
\hline 5 & -24.2 & 0.81 & 1.34 & 0.17 & 0.54 & 0.25 \\
\hline 6 & -21.1 & 0.24 & 0.65 & 0.08 & 0.11 & 0.16 \\
\hline 7 & -25.0 & 2.67 & 1.19 & 0.89 & 0.58 & 0.28 \\
\hline 8 & -23.7 & 1.24 & 1.43 & 0.37 & 0.42 & 0.26 \\
\hline 9 & -24.7 & 1.08 & 1.31 & 0.40 & 0.44 & 0.28 \\
\hline 10 & -25.2 & 3.02 & 0.91 & 0.92 & 0.88 & 0.41 \\
\hline 11 & -24.2 & 3.12 & 1.11 & 1.00 & 0.67 & 0.30 \\
\hline 12 & -21.5 & 0.15 & 0.29 & 0.09 & 0.24 & 0.22 \\
\hline 13 & -22.9 & 0.36 & 0.57 & 0.22 & 0.24 & 0.26 \\
\hline 14 & -22.5 & 0.27 & 0.95 & 0.08 & 0.11 & 0.16 \\
\hline 15 & -22.1 & 0.46 & 2.17 & 0.10 & 0.31 & 0.14 \\
\hline 16 & -22.6 & 0.18 & 0.67 & 0.09 & 0.23 & 0.22 \\
\hline 17 & -21.5 & 0.25 & 0.47 & 0.13 & 0.15 & 0.14 \\
\hline 18 & -26.3 & 0.41 & 1.12 & 0.07 & 0.24 & 0.59 \\
\hline 19 & -23.8 & 0.26 & 0.74 & 0.08 & 0.05 & 0.13 \\
\hline 20 & -23.4 & 0.83 & 0.91 & 0.24 & 0.46 & 0.25 \\
\hline 21 & -25.6 & 3.48 & 1.25 & 1.30 & 0.65 & 0.31 \\
\hline 22 & -22.7 & 0.14 & 0.29 & 0.08 & 0.09 & 0.11 \\
\hline 23 & -21.5 & 0.16 & 0.27 & 0.09 & 0.17 & 0.15 \\
\hline 24 & -22.2 & 0.22 & 0.38 & 0.11 & 0.10 & 0.09 \\
\hline 25 & -18.5 & 0.15 & 0.20 & 0.10 & 0.12 & 0.12 \\
\hline 26 & -22.6 & 0.15 & 0.53 & 0.05 & 0.04 & 0.11 \\
\hline 27 & -23.6 & 0.15 & 0.75 & 0.09 & 0.10 & 0.15 \\
\hline 28 & -20.2 & 0.21 & 0.51 & 0.06 & 0.09 & 0.11 \\
\hline 29 & -24.8 & 0.17 & 0.50 & 0.06 & 0.12 & 0.12 \\
\hline 30 & -21.0 & 0.24 & 0.46 & 0.14 & 0.07 & 0.08 \\
\hline 31 & -26.2 & 0.16 & 0.27 & 0.06 & 0.09 & 0.08 \\
\hline 32 & -24.8 & 0.19 & 0.15 & 0.08 & 0.13 & 0.10 \\
\hline 33 & -20.8 & 0.10 & 0.26 & 0.04 & 0.08 & 0.08 \\
\hline 34 & -25.4 & 0.22 & 0.72 & 0.05 & 0.15 & 0.19 \\
\hline 35 & -22.6 & 0.13 & 0.25 & 0.06 & 0.07 & 0.08 \\
\hline 36 & -20.8 & 0.56 & 0.84 & 0.25 & 0.32 & 0.35 \\
\hline 37 & -22.8 & 3.53 & 0.83 & 1.51 & 0.64 & 0.26 \\
\hline 38 & -25.2 & 0.37 & 0.94 & 0.06 & 0.20 & 0.33 \\
\hline 39 & -18.9 & 0.14 & 0.53 & 0.04 & 0.06 & 0.11 \\
\hline 40 & -27.2 & 3.12 & 0.23 & 0.83 & 1.37 & 0.17 \\
\hline
\end{tabular}

The suffix: $o=$ extraction with oxalate; $p=$ extraction with pirophosphate 


\section{Continuation appendix 2.1}

\begin{tabular}{|c|c|c|c|c|c|c|c|}
\hline \multirow{2}{*}{ \# } & \multicolumn{7}{|c|}{ Forest } \\
\hline & $\begin{array}{c}\begin{array}{c}\text { Biomasa } \\
\text { (ton/ha) }\end{array} \\
\end{array}$ & $\delta^{13} \mathrm{C}$ & $\mathrm{Al}_{\circ}(\%)$ & $\mathrm{Fe}_{\circ}(\%)$ & $\mathrm{Si}_{\mathrm{o}}(\%)$ & $\mathrm{Al}_{\mathrm{p}}(\%)$ & $\mathrm{Fe}_{\mathrm{p}}(\%)$ \\
\hline 1 & 184.1 & -26.8 & 0.44 & 1.51 & 0.09 & 0.25 & 0.43 \\
\hline 2 & 247.8 & -26.8 & 0.41 & 0.93 & 0.06 & 0.26 & 0.35 \\
\hline 3 & 291.3 & -27.3 & 0.20 & 0.84 & 0.07 & 0.05 & 0.17 \\
\hline 4 & 178.9 & -27.0 & 0.66 & 1.37 & 0.10 & 0.55 & 0.25 \\
\hline 5 & 162.4 & -26.7 & 2.31 & 1.47 & 0.96 & 0.60 & 0.23 \\
\hline 6 & 240.8 & -26.3 & 0.22 & 0.72 & 0.09 & 0.13 & 0.13 \\
\hline 7 & 213.0 & -26.8 & 2.27 & 1.29 & 0.67 & 0.68 & 0.39 \\
\hline 8 & 145.4 & -27.2 & 1.31 & 1.23 & 0.38 & 0.49 & 0.29 \\
\hline 9 & 147.7 & -26.4 & 1.06 & 1.34 & 0.38 & 0.50 & 0.32 \\
\hline 10 & 193.8 & -25.9 & 2.73 & 1.25 & 0.82 & 0.71 & 0.39 \\
\hline 11 & 229.4 & -26.9 & 2.63 & 0.75 & 0.82 & 0.77 & 0.36 \\
\hline 12 & 138.4 & -23.3 & 0.21 & 0.14 & 0.12 & 0.19 & 0.15 \\
\hline 13 & 172.9 & -24.1 & 0.18 & 0.21 & 0.11 & 0.15 & 0.15 \\
\hline 14 & 173.8 & -23.3 & 0.30 & 1.00 & 0.09 & 0.20 & 0.23 \\
\hline 15 & 119.5 & -26.5 & 0.48 & 2.14 & 0.12 & 0.25 & 0.10 \\
\hline 16 & 135.0 & -24.7 & 0.19 & 0.52 & 0.09 & 0.26 & 0.24 \\
\hline 17 & 154.6 & -25.7 & 0.22 & 0.29 & 0.12 & 0.25 & 0.21 \\
\hline 18 & 228.2 & -27.8 & 0.32 & 0.92 & 0.06 & 0.25 & 0.54 \\
\hline 19 & 277.4 & -27.3 & 0.35 & 0.75 & 0.07 & 0.20 & 0.52 \\
\hline 20 & 137.2 & -23.8 & 0.89 & 0.81 & 0.26 & 0.38 & 0.29 \\
\hline 21 & 138.8 & -25.8 & 2.97 & 1.21 & 1.15 & 0.55 & 0.24 \\
\hline 22 & 111.8 & -24.5 & 0.17 & 0.18 & 0.09 & 0.09 & 0.06 \\
\hline 23 & 133.9 & -26.4 & 0.16 & 0.29 & 0.09 & 0.11 & 0.10 \\
\hline 24 & 198.8 & -27.3 & 0.15 & 0.65 & 0.09 & 0.06 & 0.09 \\
\hline 25 & 144.6 & -25.4 & 0.22 & 0.11 & 0.12 & 0.11 & 0.07 \\
\hline 26 & 132.0 & -25.8 & 0.15 & 0.47 & 0.05 & 0.05 & 0.12 \\
\hline 27 & 121.5 & -28.1 & 0.18 & 0.66 & 0.09 & 0.08 & 0.12 \\
\hline 28 & 157.4 & -26.4 & 0.15 & 0.53 & 0.05 & 0.06 & 0.13 \\
\hline 29 & 121.9 & -25.4 & 0.17 & 0.37 & 0.07 & 0.13 & 0.14 \\
\hline 30 & 85.8 & -25.6 & 0.18 & 0.48 & 0.10 & 0.07 & 0.10 \\
\hline 31 & 169.8 & -26.4 & 0.17 & 0.44 & 0.06 & 0.10 & 0.10 \\
\hline 32 & 158.7 & -26.2 & 0.17 & 0.16 & 0.07 & 0.14 & 0.11 \\
\hline 33 & 198.1 & -24.3 & 0.16 & 0.33 & 0.05 & 0.05 & 0.07 \\
\hline 34 & 163.3 & -27.2 & 0.14 & 0.52 & 0.05 & 0.05 & 0.10 \\
\hline 35 & 199.1 & -25.8 & 0.17 & 0.19 & 0.06 & 0.04 & 0.04 \\
\hline 36 & 107.7 & -22.1 & 0.67 & 0.87 & 0.30 & 0.37 & 0.33 \\
\hline 37 & 155.1 & -24.1 & 3.51 & 0.78 & 1.33 & 0.79 & 0.33 \\
\hline 38 & 156.6 & -28.0 & 0.40 & 0.93 & 0.09 & 0.20 & 0.34 \\
\hline 39 & 127.3 & -27.7 & 0.14 & 0.25 & 0.03 & 0.05 & 0.05 \\
\hline 40 & 174.3 & -27.3 & 4.50 & 0.37 & 1.51 & 1.30 & 0.22 \\
\hline
\end{tabular}


Appendix 3.1: List of herbs species in each land use system (Manabi-Ecuador)

\section{Family and Species}

$\begin{array}{lll}\text { Coffee } & \text { Pasture } & \text { Rice }\end{array}$

\begin{tabular}{|c|c|c|}
\hline AMARANTHACEAE & AMARANTHACEAE & ACANTHACEAE \\
\hline Achyranthes aspera & Achyranthes aspera & Justicia comata \\
\hline ACANTHACEAE & ACANTHACEAE & Ruellia sp. \\
\hline Justicia comata & Justicia comata & ALISMATACEAE \\
\hline Ruellia sp. 1 & Ruellia sp. 1 & Echinodorus sp. \\
\hline ALSTROEMERIACEAE & ALISMATACEAE & ALSTROEMERIACEAE \\
\hline Bomarea obovata & Echinodorus sp. & Bomarea obovata \\
\hline AMARANTHACEAE & ALSTROEMERIACEAE & AMARANTHACEAE \\
\hline Althernanthera areschougii & Bomarea obovata & Achyranthes aspera \\
\hline Althernanthera pubiflora & AMARANTHACEAE & Althernanthera areschougii \\
\hline Iresine diffusa & Amaranthus spinosus & Amaranthus sp. \\
\hline APOCYNACEAE & Iresine angustifolia & Amaranthus spinosus \\
\hline Mandevilla subsagittata & Iresine diffusa & APIACEAE \\
\hline Mesechites trifida & APOCYNACEAE & Eryngium foetidum \\
\hline Prestonia mollis & Prestonia mollis & APOCYNACEAE \\
\hline Tabernaemontana amygdalifolia & Prestonia rotundifolia & Mandevilla subsagittata \\
\hline ARACEAE & Tabernaemontana amygdalifolia & Mesechites trifida \\
\hline Syngonium sp. & ARACEAE & Prestonia mollis \\
\hline Xanthosoma cf. eggersii & Caladium bicolour & Tabernaemontana amygdalifolia \\
\hline ARISTOLOCHIACEAE & Xanthosoma cf. eggersii & ARACEAE \\
\hline Aristolochia odoratissima & Xanthosoma daguense & Chlorospatha sp. \\
\hline Aristolochia pilosa & ARISTOLOCHIACEAE & Xanthosoma cf. eggersii \\
\hline ASCLEPIADACEAE & Aristolochia odoratissima & ARISTOLOCHIACEAE \\
\hline Gonolobus sp. & Aristolochia pilosa & Aristolochia odoratissima \\
\hline Marsdenia sp.3 & ASCLEPIADACEAE & Aristolochia pilosa \\
\hline ASTERACEAE & Asclepias curassavica & ASCLEPIADACEAE \\
\hline Acmella sp. & Macroscepis sp. & Marsdenia sp. 2 \\
\hline Adenostemma platyphyllum & Marsdenia sp. 2 & Matelea sp. \\
\hline Adenostemma sp. & Matelea sp. & ASTERACEAE \\
\hline Baltimora recta & ASTERACEAE & Acanthospemum microcarpum \\
\hline Chromolaena scabra & Acmella alba & Acmella alba \\
\hline Jungia sp. & Adenostemma platyphyllum & Acmella sp. \\
\hline
\end{tabular}


Mikania sp.

Pseudelephantopus spicathus

Synedrella nodiflora

BIGNONIACEAE

Amphilophium paniculatum

Macfadyena unguis-cati

CAESALPINIACEAE

Senna obtusifolia

CAPPARACEAE

Podandrogyne brachycarpa

CARYOPHYLLACEAE

Drymaria cordata

COMMELINACEAE

Callisia gracilis

Commelina erecta

CONVOLVULACEAE

Ipomoea setosa

Merremia umbellata

CUCURBITACEAE

Melothria pendula

Momordica charantia

Rytidostylis carthaginensis

Sicyos sp.

CYPERACEAE

Rynchospora contracta

DIOSCOREACEAE

Dioscorea piperifolia

DRYOPTERIDACEAE

Athyrium doodlei

Athyrium sp.

Cyclopeltis semicordata

Tectaria sp. 1

Tectaria sp. 3

EUPHORBIACEAE

Euphorbia graminea

FABACEAE

Canavalia $s p$

Desmodium cf. incanum

Desmodium sp. 3

GESNERIACEAE
Adenostemma sp.

Ageratina sp.

Ageratum conyzoides

Austroeupatorium inulaefolium

Baltimora recta

Chaptalia nutans

Chromolaena scabra

Conyza bonariensis

Delilia biflora

Eclipta prostrata

Egletes viscosa

Erechtites hieraciifolius

Eupatorium sp. 2

Isocarpha microcephala

Jungia sp.

Jungia sp.2

Liabum eggersii

Lycoseris trinervis

Mikania cordifolia

Mikania $s p$

Pseudelephantopus spicathus

Sphagneticola trilobata

Synedrella nodiflora

Tridax procumbens

BIGNONIACEAE

Amphilophium paniculatum

Macfadyena unguis-cati

CAESALPINIACEAE

Chamaecrista nictitans

Senna obtusifolia

CAMPANULACEAE

Burmeistera sp.

CAPPARACEAE

Podandrogyne brachycarpa

CARYOPHYLLACEAE

Drymaria cordata

Stellaria ovata

COMMELINACEAE

Commelina erecta

CONVOLVULACEAE
Adenostemma platyphyllum

Adenostemma sp.

Ageratina sp.

Austroeupatorium inulaefolium

Baltimora recta

Brickellia diffusa

Chromolaena roseorum

Conyza bonariensis

Egletes sp.

Egletes viscose

Eupatorium sp. 1

Fleischmannia microstemon

Isocarpha microcephala

Jungia sp. 1

Jungia sp. 2

Liabum eggersii

Mikania cordifolia

Mikania sp.

Pseudelephantopus spicathus

Tridax procumbens

Vernonia $s p$

\section{BEGONIACEAE}

Begonia serotina

Macfadyena unguis-cati

BORAGINACEAE

Heliotropium cf. rufipillum

CAESALPINIACEAE

Chamaecrista nictitans

Senna obtusifolia

Senna sp.

\section{CARYOPHYLLACEAE}

Drymaria cordata

COMMELINACEAE

Commelina erecta

CONVOLVULACEAE

Ipomoea batatas

Ipomoea meyeri

Ipomoea sp.

Merremia umbellate

CYPERACEAE 
Diastema racemiferum

HELICONIACEAE

Heliconia latispatha

LAMIACEAE

Hyptis mutabilis vel pectinata

Salvia occidentalis

LOASACEAE

Klaprothia fasciculata

MALVACEAE

Sida repens

Sida sp. 6

MENISPERMEACEAE

Cissampelos tropaeolifolia

MORACEAE

Dorstenia contrajerva

MORACEAE

Oxalis glauca

PASSIFLORACEAE

Passiflora filipes

Passiflora punctata

PHYTOLACCACEAE

Microtea debilis

Petiveria alliacea

PIPERACEAE

Peperomia pellucida

Peperomia rotundifolia

Piper marginatum

Piper peltatum

POACEAE

Echinolaena aequatoriana

Oplismenus burmanii

Oplismenus hirtellus

Panicum trichoides

Paspalum conjugatum

Paspalum microstachyum

Paspalum sp. 1

POLYPODIACEAE

Micrograma sp.

PORTULACACEAE

Talinum paniculatum
Merremia umbellata

CUCURBITACEAE

Cayaponia sp.

Momordica charantia

Posadaea sphaerocarpa

CYPERACEAE

Cyperus cf. hermaphroditus

Cyperus chalaranthus

Cyperus compressus

Cyperus odoratus

Cyperus panamensis

Cyperus sp.

Cyperus surinamensis

Kyllingia brevifolia

Rynchospora contracta

Rynchospora radicans

Rynchospora sp.

Scleria melaleuca

DRYOPTERIDACEAE

Diplazium sp.

\section{EUPHORBIACEAE}

Chamaesyce cf. ophtalmica

Chamaesyce hirta

Croton hirtus

Phyllanthus caroliniensis

Phyllanthus niruri

FABACEAE

Aeschynomene sp.

Calapagonium mucunoides

Centrosema pubescens

Desmodium cf. distortum

Desmodium cf. incanum

Desmodium scorpiurus

Desmodium sp. 1

Macroptilium cf. lathyroides

Phaseolus sp.

Rhynchosia minima

HELICONIACEAE

Heliconia latispatha

HYDROPHYLLACEAE
Cyperus cf. hermaphroditus

Cyperus chalaranthus

Cyperus compressus

Cyperus iria

Cyperus odoratus

Cyperus panamensis

Cyperus sp.

Cyperus surinamensis

Fimbristylis annua

Kyllingia brevifolia

Rynchospora contracta

Scleria melaleuca

EUPHORBIACEAE

Acalypha cf. cuspidate

Acalypha subcastrata

Chamaesyce cf. ophtalmica

Chamaesyce hirta

Euphorbia graminea

Phyllanthus niruri

FABACEAE

Aeschynomene sp.

Cajanus cajan

Centrosema sp.

Desmodium cf. incanum

Desmodium scorpiurus

Desmodium sp. 2

Desmodium sp. 3

Macroptilium cf. lathyroides

Phaseolus sp.

Rhynchosia minima

Vigna vexillata

HELICONIACEAE

Heliconia latispatha

LAMIACEAE

Hyptis pectinata

Hyptis savannarum

Salvia sp. 2

\section{LOASACEAE}

Klaprothia fasciculate

LOGANIACEAE 


\section{PTERIDACEAE}

Adiantum alarconianum

Adiantum sp.

Pityrogramma calomelanos

RUBIACEAE

Borreria sp.

Psychotria sp.

\section{SAPINDACEAE}

Serjania sp.2

\section{SCHIZAEACEAE}

Lygodium venustum

SCROPHULARIACEAE

Lindernia crustacea

Scoparia dulcis

SOLANACEAE

Acnistus arborescens

Physalis angulata

Solanum americanum

Solanum anceps

THELYPTERIDACEAE

Thelypteris $s p .1$

Thelypteris sp. 2

Thelypteris sp. 3

URTICACEAE

Laportea aestuans

Pilea baurii

Urera cf. baccifera

VERBENACEAE

Priva lappulacea

VITACEAE

Cissus verticillata
Hydrolea spinosa

\section{LAMIACEAE}

Hyptis mutabilis

Hyptis pectinata

Hyptis savannarum

Salvia occidentalis

Salvia $s p .2$

\section{LOASACEAE}

Klaprothia fasciculata

LYTHRACEAE

Adenaria floribunda

Cuphea strigulosa

Rotala ramosior

MALVACEAE

Malachra alceifolia

Malachra fasciata

Sida poeppigiana

Sida repens

Sida rhombifolia

Sida $s p .1$

MARANTACEAE

Calathea sp.

MIMOSACEAE

Albizzia sp.

NYCTAGINACEAE

Boerhavia coccinea

ONAGRACEAE

Ludwigia erecta

Ludwigia peruviana

OXALIDACEAE

Oxalis glauca

PASSIFLORACEAE

Passiflora filipes

Passiflora foetida

Passiflora punctata

Passiflora sprucei

PHYTOLACCACEAE

Microtea debilis

Petiveria alliacea

PIPERACEAE
Mitreola petiolata

\section{LYTHRACEAE}

Ammania auriculata

Cuphea strigulosa

Rotala ramosior

MALPHIGIACEAE

Heteropterys aequatorialis

MALVACEAE

Malachra alceifolia

Sida poeppigiana

Sida repens

Sida rhombifolia

Sida $s p .2$

Sida sp. 3

NYCTAGINACEAE

Mirabilis violacea

ONAGRACEAE

Eclipta prostrate

Ludwigia erecta

\section{ORCHIDACEAE}

Stenorhyncos cf. lanceolata

OXALIDACEAE

Oxalis glauca

\section{PHYTOLACCACEAE}

Microtea debilis

PIPERACEAE

Peperomia pellucida

Peperomia stilifera

Piper bredemeyeri

Piper marginatum

Piper peltatum

Piper sp. 1

Piper sp. 2

POACEAE

Chloris radiate

Digitaria sp.

Echinochloa colona

Echinolaena aequatoriana

Eleusine indica

Eragrostis amabilis 
Peperomia pellucida

Piper bredemeyeri

Piper marginatum

Piper peltatum

POACEAE

Echinochloa colona

Echinolaena aequatoriana

Eleusine indica

Lasiacis sorghoidea

Oplismenus burmanii

Oplismenus hirtellus

Panicum laxum

Panicum polygonatum

Panicum sp. 1

Paspalum conjugatum

Paspalum microstachyum

Paspalum paniculatum

Paspalum sp. 1

Urochloa fasciculata

PONTEDERIACEAE

Heteranthera reniformis

PTERIDACEAE

Adiantum alarconianum

Adiantum concinnum

Adiantum sp.

Pityrogramma calomelanos

RUBIACEAE

Borreria ocymoides

Borreria sp.

SCHIZAEACEAE

Lygodium venustum

SCROPHULARIACEAE

Lindernia crustacea

Mecardonia procumbens

Scoparia dulcis

SMILACACEAE

Smilax lappacea

SOLANACEAE

Browallia americana

Physalis angulata
Eragrostis ciliaris

Eragrostis japonica

Eragrostis sp.

Isaemum rugosum

Leptochloa virgata

Oplismenus burmanii

Oplismenus hirtellus

Panicum maximum

Panicum polygonatum

Panicum sp. 2

Panicum trichoides

Paspalum conjugatum

Paspalum microstachyum

Paspalum paniculatum

Paspalum sp. 1

Sporobulus tenuissimus

Urochloa fasciculate

Zea mays

POLYGALACEAE

Securidaca cf. coriacea

PONTEDERIACEAE

Heteranthera reniformis

PORTULACACEAE

Petiveria alliacea

Portulaca oleracea

Talinum paniculatum

\section{PTERIDACEAE}

Adiantum concinnum

Adiantum sp.

Pityrogramma calomelanos

RUBIACEAE

Borreria ocymoides

Borreria sp.

SAPINDACEAE

Serjania sp. 3

\section{SCHIZAEACEAE}

Lygodium venustum

SCROPHULARIACEAE

Bacopa monniera

Lindernia crustacean 
Solanum americanum

Solanum candidum

Solanum caricaefolium

Solanum quitoense

Solanum sp. 3

STERCULIACEAE

Melochia lupulina

THELYPTERIDACEAE

Thelypteris subgenero Gonioptheris

TILIACEAE

Corchorus orinocensis

Triumfetta sp.

\section{URTICACEAE}

Phenax laevigatus

Pilea baurii

Urera cf. baccifera

VERBENACEAE

Priva lappulacea

Stachytarpheta cayennensis

\section{VIOLACEAE}

Hybanthus attenuatus

VITACEAE

Cissus sp.

Cissus verticillata
Mecardonia procumbens

Scoparia dulcis

Stemodia durantifolia

SMILACEACEAE

Smilax lappacea

SOLANACEAE

Browallia americana

Physalis angulata

Solanum cf. pimpinellifolium

Solanum quitoense

Solanum sp. 3

STERCULIACEAE

Melochia Iupulina

\section{THELYPTERIDACEAE}

Thelypteris sp. 3

Thelypteris subgenero Gonioptheris

TILIACEAE

Corchorus orinocensis

Triumfetta sp.

ULMACEAE

Trema micrantha

URTICACEAE

Laportea aestuans

Phenax rugosus

Pilea baurii

Urera cf. baccifera

VERBENACEAE

Phyla nodiflora

Phyla strigulosa

Priva lappulacea

Stachytarpheta cayennensis
Total Families $=45$

Total Species $=98$

Total Families $=\mathbf{5 1}$

Total Species $=165$
Total Families $=49$

Total Species $=174$ 
Appendix 3.2: General database for chapter 3

\begin{tabular}{|c|c|c|c|c|c|c|c|c|c|c|}
\hline ID & X (UTM) & $\mathrm{Y}(\mathrm{UTM})$ & Landuse & Landform & Slope $\left({ }^{\circ}\right)$ & Elevation $(\mathrm{m})$ & Age (yr) & Sand $(\%)$ & Silt (\%) & Clay $(\%)$ \\
\hline 1 & 566670 & 9844870 & 1 & 1 & 0 & 145 & 15 & 27 & 46 & 27 \\
\hline 2 & 570482 & 9841336 & 1 & 2 & 3 & 228 & 25 & 31 & 40 & 29 \\
\hline 3 & 569803 & 9832226 & 1 & 1 & 0 & 132 & 30 & 27 & 48 & 25 \\
\hline 4 & 570716 & 9837024 & 1 & 1 & 0 & 126 & 30 & 43 & 32 & 25 \\
\hline 5 & 571246 & 9830485 & 1 & 1 & 0 & 148 & 30 & 27 & 38 & 35 \\
\hline 6 & 564191 & 9827161 & 1 & 1 & 0 & 136 & 40 & 17 & 44 & 39 \\
\hline 7 & 566837 & 9824511 & 1 & 1 & 0 & 125 & 8 & 41 & 35 & 24 \\
\hline 8 & 571993 & 9840142 & 1 & 2 & 15 & 198 & 20 & 35 & 33 & 32 \\
\hline 9 & 562322 & 9839314 & 1 & 2 & 20 & 467 & 30 & 29 & 40 & 31 \\
\hline 10 & 560303 & 9837364 & 1 & 2 & 5 & 471 & 20 & 49 & 29 & 22 \\
\hline 11 & 568651 & 9828048 & 1 & 2 & 30 & 194 & 8 & 37 & 35 & 28 \\
\hline 12 & 569064 & 9830574 & 1 & 2 & 2 & 190 & 40 & 29 & 39 & 32 \\
\hline 13 & 567846 & 9844972 & 2 & 1 & 16 & 160 & 25 & 39 & 32 & 29 \\
\hline 14 & 569843 & 9841319 & 2 & 2 & 5 & 180 & 20 & 35 & 36 & 29 \\
\hline 15 & 569533 & 9832121 & 2 & 1 & 12 & 130 & 50 & 21 & 40 & 39 \\
\hline 16 & 570866 & 9837350 & 2 & 1 & 10 & 136 & 9 & 21 & 34 & 45 \\
\hline 17 & 570410 & 9830749 & 2 & 1 & 0 & 121 & 40 & 17 & 43 & 40 \\
\hline 18 & 564587 & 9827113 & 2 & 1 & 0 & 125 & 30 & 51 & 27 & 22 \\
\hline 19 & 567452 & 9824316 & 2 & 1 & 3 & 160 & 20 & 61 & 25 & 14 \\
\hline 20 & 571780 & 9840111 & 2 & 2 & 8 & 186 & 30 & 19 & 37 & 44 \\
\hline 21 & 561598 & 9840014 & 2 & 2 & 20 & 477 & 20 & 33 & 32 & 35 \\
\hline 22 & 560441 & 9837259 & 2 & 2 & 15 & 471 & 30 & 47 & 27 & 26 \\
\hline 23 & 569287 & 9828324 & 2 & 2 & 34 & 193 & 14 & 43 & 29 & 28 \\
\hline 24 & 568947 & 9830546 & 2 & 2 & 10 & 187 & 40 & 35 & 33 & 32 \\
\hline 25 & 565629 & 9844318 & 3 & 1 & 0 & 156 & 2 & 31 & 44 & 25 \\
\hline 26 & 569801 & 9841059 & 3 & 2 & 9 & 179 & 8 & 21 & 34 & 45 \\
\hline 27 & 569803 & 9832126 & 3 & 1 & 0 & 126 & 5 & 15 & 40 & 45 \\
\hline 28 & 570716 & 9837018 & 3 & 1 & 0 & 126 & 10 & 31 & 33 & 36 \\
\hline 29 & 570695 & 9830614 & 3 & 1 & 0 & 119 & 6 & 11 & 24 & 65 \\
\hline 30 & 564833 & 9826975 & 3 & 1 & 0 & 120 & 7 & 43 & 28 & 29 \\
\hline 31 & 566908 & 9824383 & 3 & 1 & 25 & 105 & 4 & 49 & 23 & 28 \\
\hline 32 & 571901 & 9840298 & 3 & 2 & 12 & 189 & 8 & 31 & 31 & 38 \\
\hline 33 & 562412 & 9839223 & 3 & 2 & 8 & 471 & 2 & 29 & 37 & 34 \\
\hline 34 & 560684 & 9837713 & 3 & 2 & 10 & 470 & 5 & 29 & 37 & 34 \\
\hline 35 & 568962 & 9828204 & 3 & 2 & 20 & 175 & 2 & 41 & 37 & 22 \\
\hline 36 & 569064 & 9830574 & 3 & 2 & 2 & 190 & 6 & 29 & 35 & 36 \\
\hline
\end{tabular}

Landuse: coffee $=1$, pasture $=2$, rice $=3$; landform: lowland soils $=1$; uplands soils $=2$ 


\section{Continuation appendix 3.2 (Herbs)}

\begin{tabular}{|c|c|c|c|c|c|c|c|c|c|}
\hline ID & Total Indiv. & Winter spec. & Summer spec. & Total spec. & Alpha & Beta & Gamma & Rel. Alpha & Rel.Beta \\
\hline 1 & 105 & 25 & 11 & 29.0 & 6.4 & 22.6 & 29.0 & 0.22 & 0.78 \\
\hline 2 & 512 & 30 & 16 & 38.0 & 9.8 & 28.2 & 38.0 & 0.26 & 0.74 \\
\hline 3 & 159 & 17 & 2 & 17.0 & 3.8 & 13.2 & 17.0 & 0.22 & 0.78 \\
\hline 4 & 180 & 17 & 2 & 19.0 & 3.9 & 15.1 & 19.0 & 0.20 & 0.8 \\
\hline 5 & 304 & 16 & 1 & 16.0 & 2.8 & 13.2 & 16.0 & 0.17 & 0.83 \\
\hline 6 & 415 & 18 & 0 & 18.0 & 4.9 & 13.1 & 18.0 & 0.27 & 0.73 \\
\hline 7 & 57 & 10 & 1 & 11.0 & 1.9 & 9.1 & 11.0 & 0.17 & 0.83 \\
\hline 8 & 228 & 29 & 8 & 32.0 & 6.9 & 25.1 & 32.0 & 0.22 & 0.78 \\
\hline 9 & 373 & 31 & 17 & 38.0 & 11.7 & 26.3 & 38.0 & 0.31 & 0.69 \\
\hline 10 & 218 & 28 & 10 & 29.0 & 8.7 & 20.3 & 29.0 & 0.30 & 0.7 \\
\hline 11 & 169 & 26 & 10 & 29.0 & 6.2 & 22.8 & 29.0 & 0.21 & 0.79 \\
\hline 12 & 627 & 31 & 12 & 35.0 & 9.6 & 25.4 & 35.0 & 0.27 & 0.73 \\
\hline 13 & 621 & 18 & 20 & 33.0 & 8.7 & 24.3 & 33.0 & 0.26 & 0.74 \\
\hline 14 & 343 & 38 & 18 & 40.0 & 12.1 & 27.9 & 40.0 & 0.30 & 0.7 \\
\hline 15 & 512 & 39 & 13 & 40.0 & 12.0 & 28.0 & 40.0 & 0.30 & 0.7 \\
\hline 16 & 326 & 29 & 12 & 35.0 & 7.3 & 27.7 & 35.0 & 0.21 & 0.79 \\
\hline 17 & 305 & 40 & 8 & 39.0 & 10.1 & 28.9 & 39.0 & 0.26 & 0.74 \\
\hline 18 & 832 & 30 & 15 & 39.0 & 10.7 & 28.3 & 39.0 & 0.27 & 0.73 \\
\hline 19 & 303 & 38 & 8 & 40.0 & 11.1 & 28.9 & 40.0 & 0.28 & 0.72 \\
\hline 20 & 58 & 19 & 3 & 19.0 & 4.1 & 14.9 & 19.0 & 0.22 & 0.78 \\
\hline 21 & 667 & 62 & 15 & 66.0 & 13.9 & 52.1 & 66.0 & 0.21 & 0.79 \\
\hline 22 & 645 & 39 & 10 & 41.0 & 11.0 & 30.0 & 41.0 & 0.27 & 0.73 \\
\hline 23 & 637 & 47 & 17 & 56.0 & 17.4 & 38.6 & 56.0 & 0.31 & 0.69 \\
\hline 24 & 85 & 26 & 7 & 27.0 & 4.2 & 22.8 & 27.0 & 0.16 & 0.84 \\
\hline 25 & 473 & 33 & 29 & 50.0 & 13.8 & 36.2 & 50.0 & 0.28 & 0.72 \\
\hline 26 & 1063 & 22 & 13 & 30.0 & 10.1 & 19.9 & 30.0 & 0.34 & 0.66 \\
\hline 27 & 444 & 25 & 12 & 32.0 & 10.3 & 21.7 & 32.0 & 0.32 & 0.68 \\
\hline 28 & 365 & 15 & 8 & 21.0 & 7.0 & 14.0 & 21.0 & 0.33 & 0.67 \\
\hline 29 & 770 & 9 & 11 & 18.0 & 5.6 & 12.4 & 18.0 & 0.31 & 0.69 \\
\hline 30 & 1168 & 33 & 11 & 39.0 & 11.4 & 27.6 & 39.0 & 0.29 & 0.71 \\
\hline 31 & 1055 & 40 & 19 & 53.0 & 11.9 & 41.1 & 53.0 & 0.22 & 0.78 \\
\hline 32 & 448 & 35 & 14 & 41.0 & 12.0 & 29.0 & 41.0 & 0.29 & 0.71 \\
\hline 33 & 595 & 39 & 12 & 45.0 & 11.9 & 33.1 & 45.0 & 0.26 & 0.74 \\
\hline 34 & 315 & 43 & 14 & 48.0 & 11.1 & 36.9 & 48.0 & 0.23 & 0.77 \\
\hline 35 & 291 & 39 & 23 & 51.0 & 12.7 & 38.3 & 51.0 & 0.25 & 0.75 \\
\hline 36 & 42 & 36 & 11 & 40.0 & 11.7 & 28.3 & 40.0 & 0.29 & 0.71 \\
\hline
\end{tabular}

Ind.: herbs individuals; spec: herb species; Rel.: relative herb diversity 


\section{Continuation appendix 3.2 (soil characteristics)}

\begin{tabular}{|c|c|c|c|c|c|c|c|c|}
\hline ID & $\mathrm{pH}$ & $\mathrm{BD}$ & $\mathrm{C}(\mathrm{mg} / \mathrm{g})$ & $\mathrm{N}(\mathrm{mg} / \mathrm{g})$ & $\mathrm{C} / \mathrm{N}$ & $P(\mathrm{mg} / \mathrm{g})$ & $\mathrm{Na}(\mathrm{mmol} / \mathrm{kg})$ & $\mathrm{K}(\mathrm{mmol} / \mathrm{kg})$ \\
\hline 1 & 5.07 & 1.10 & 30.92 & 2.98 & 10.30 & 1.16 & 0.52 & 26.58 \\
\hline 2 & 5.93 & 1.11 & 25.14 & 2.62 & 9.58 & 1.03 & 0.29 & 21.38 \\
\hline 3 & 5.54 & 1.10 & 20.75 & 2.11 & 9.68 & 0.82 & 0.47 & 15.83 \\
\hline 4 & 4.76 & 1.09 & 24.42 & 2.55 & 9.60 & 0.91 & 0.41 & 18.38 \\
\hline 5 & 6.21 & 1.00 & 34.12 & 3.12 & 10.92 & 1.01 & 0.79 & 11.84 \\
\hline 6 & 6.63 & 1.00 & 32.81 & 3.10 & 10.57 & 1.24 & 0.40 & 38.93 \\
\hline 7 & 6.09 & 1.15 & 23.36 & 2.29 & 10.16 & 0.99 & 0.49 & 11.79 \\
\hline 8 & 6.16 & 1.09 & 23.46 & 2.29 & 10.09 & 0.97 & 0.30 & 20.30 \\
\hline 9 & 6.38 & 1.18 & 22.55 & 2.14 & 10.50 & 0.56 & 0.52 & 4.87 \\
\hline 10 & 6.06 & 1.10 & 18.52 & 1.72 & 10.77 & 1.17 & 0.42 & 28.65 \\
\hline 11 & 6.69 & 1.17 & 28.70 & 2.47 & 11.32 & 1.69 & 0.38 & 9.05 \\
\hline 12 & 6.48 & 1.09 & 36.11 & 3.36 & 10.72 & 0.92 & 0.54 & 12.83 \\
\hline 13 & 6.43 & 1.11 & 21.24 & 2.07 & 10.21 & 0.85 & 0.58 & 20.98 \\
\hline 14 & 6.06 & 1.23 & 20.02 & 1.91 & 10.45 & 0.73 & 1.16 & 8.96 \\
\hline 15 & 6.11 & 1.15 & 21.97 & 2.18 & 10.10 & 0.79 & 1.72 & 6.49 \\
\hline 16 & 6.14 & 1.11 & 26.15 & 2.48 & 10.60 & 0.95 & 0.72 & 12.87 \\
\hline 17 & 6.06 & 1.11 & 33.43 & 3.13 & 10.68 & 1.23 & 0.94 & 27.65 \\
\hline 18 & 6.20 & 1.27 & 20.86 & 2.02 & 10.30 & 1.39 & 0.72 & 9.95 \\
\hline 19 & 6.04 & 1.32 & 14.86 & 1.52 & 9.78 & 0.67 & 0.18 & 4.50 \\
\hline 20 & 6.12 & 1.05 & 38.03 & 3.31 & 11.44 & 0.87 & 0.72 & 11.36 \\
\hline 21 & 6.13 & 1.08 & 23.67 & 2.08 & 11.24 & 0.50 & 0.93 & 6.68 \\
\hline 22 & 6.33 & 1.07 & 25.98 & 2.21 & 11.67 & 1.02 & 0.62 & 20.59 \\
\hline 23 & 6.80 & 1.35 & 15.65 & 1.53 & 10.13 & 1.79 & 0.36 & 7.53 \\
\hline 24 & 6.24 & 1.21 & 30.44 & 2.77 & 10.94 & 0.91 & 0.58 & 12.92 \\
\hline 25 & 7.11 & 1.18 & 21.83 & 2.22 & 9.75 & 0.85 & 0.36 & 18.20 \\
\hline 26 & 5.89 & 1.14 & 22.56 & 2.28 & 9.84 & 0.85 & 1.98 & 9.76 \\
\hline 27 & 6.73 & 1.08 & 17.19 & 1.74 & 9.79 & 0.90 & 3.62 & 9.13 \\
\hline 28 & 5.90 & 1.01 & 16.15 & 1.62 & 9.75 & 0.86 & 1.62 & 6.90 \\
\hline 29 & 6.31 & 1.01 & 22.12 & 2.09 & 10.57 & 1.20 & 2.99 & 10.75 \\
\hline 30 & 7.21 & 1.24 & 17.35 & 1.71 & 10.13 & 1.76 & 3.04 & 5.89 \\
\hline 31 & 6.45 & 1.32 & 19.42 & 1.83 & 10.57 & 0.74 & 0.38 & 6.64 \\
\hline 32 & 5.98 & 1.22 & 23.78 & 2.24 & 10.56 & 0.71 & 0.26 & 11.19 \\
\hline 33 & 5.94 & 1.08 & 22.02 & 2.07 & 10.59 & 0.49 & 0.55 & 3.90 \\
\hline 34 & 6.60 & 1.12 & 17.95 & 1.62 & 11.03 & 0.69 & 0.43 & 17.90 \\
\hline 35 & 6.99 & 1.24 & 23.58 & 2.30 & 10.09 & 1.40 & 0.39 & 8.38 \\
\hline 36 & 6.39 & 1.15 & 28.16 & 2.63 & 10.60 & 0.84 & 0.62 & 10.58 \\
\hline
\end{tabular}

$B D$ : bulk density 
Continuation appendix 3.2 (soil characteristics)

\begin{tabular}{|c|c|c|c|c|c|c|}
\hline ID & $\mathrm{Ca}(\mathrm{mmol} / \mathrm{kg})$ & $\mathrm{Mg}(\mathrm{mmol} / \mathrm{kg})$ & $\mathrm{Fe}(\mathrm{mmol} / \mathrm{kg})$ & $\mathrm{Mn}(\mathrm{mmol} / \mathrm{kg})$ & $\mathrm{Al}(\mathrm{mmol} / \mathrm{kg})$ & $\begin{array}{c}\text { ECEC } \\
(\mathrm{mmol} / \mathrm{kg})\end{array}$ \\
\hline 1 & 232.65 & 37.23 & 0.06 & 0.94 & 0.20 & 298.2 \\
\hline 2 & 241.96 & 36.17 & 0.08 & 0.92 & 0.40 & 301.2 \\
\hline 3 & 211.13 & 32.04 & 0.05 & 0.94 & 0.84 & 261.4 \\
\hline 4 & 205.59 & 32.15 & 0.06 & 1.05 & 2.72 & 261.1 \\
\hline 5 & 290.53 & 61.44 & 0.04 & 0.65 & 0.00 & 365.3 \\
\hline 6 & 310.93 & 56.61 & 0.08 & 0.35 & 0.10 & 407.4 \\
\hline 7 & 178.09 & 29.99 & 0.00 & 0.59 & 0.00 & 220.9 \\
\hline 8 & 290.31 & 39.50 & 0.02 & 1.09 & 0.84 & 352.5 \\
\hline 9 & 229.76 & 34.74 & 0.02 & 1.14 & 0.35 & 271.4 \\
\hline 10 & 220.23 & 25.45 & 0.06 & 1.02 & 0.44 & 276.3 \\
\hline 11 & 317.37 & 45.28 & 0.12 & 0.38 & 0.00 & 372.6 \\
\hline 12 & 274.78 & 37.63 & 0.04 & 1.26 & 0.49 & 327.6 \\
\hline 13 & 205.81 & 39.50 & 0.03 & 0.73 & 0.00 & 267.6 \\
\hline 14 & 175.43 & 45.17 & 0.03 & 1.06 & 0.00 & 231.8 \\
\hline 15 & 243.29 & 62.72 & 0.02 & 1.20 & 0.10 & 315.5 \\
\hline 16 & 222.67 & 84.23 & 0.04 & 0.92 & 3.76 & 325.3 \\
\hline 17 & 318.86 & 59.65 & 0.06 & 0.62 & 0.10 & 407.9 \\
\hline 18 & 179.42 & 38.77 & 0.00 & 0.74 & 0.00 & 229.6 \\
\hline 19 & 88.71 & 14.15 & 0.00 & 0.41 & 0.00 & 107.9 \\
\hline 20 & 280.11 & 76.84 & 0.00 & 1.88 & 0.00 & 370.9 \\
\hline 21 & 188.96 & 53.29 & 0.04 & 2.05 & 0.00 & 251.9 \\
\hline 22 & 234.64 & 33.83 & 0.01 & 1.16 & 0.10 & 290.9 \\
\hline 23 & 228.65 & 37.30 & 0.00 & 0.41 & 0.10 & 274.4 \\
\hline 24 & 237.08 & 48.49 & 0.01 & 1.75 & 0.15 & 301.0 \\
\hline 25 & 225.88 & 31.29 & 0.08 & 0.13 & 0.15 & 276.1 \\
\hline 26 & 251.28 & 79.03 & 0.03 & 0.91 & 0.49 & 343.5 \\
\hline 27 & 270.57 & 81.63 & 0.07 & 0.41 & 0.15 & 365.6 \\
\hline 28 & 211.80 & 71.72 & 0.02 & 0.65 & 3.95 & 296.7 \\
\hline 29 & 377.25 & 133.78 & 0.08 & 0.30 & 0.20 & 525.3 \\
\hline 30 & 261.26 & 58.41 & 0.00 & 0.21 & 0.00 & 328.8 \\
\hline 31 & 197.61 & 41.95 & 0.00 & 0.26 & 0.00 & 246.8 \\
\hline 32 & 202.71 & 56.98 & 0.00 & 0.97 & 0.20 & 272.3 \\
\hline 33 & 169.44 & 42.94 & 0.02 & 1.99 & 0.84 & 219.7 \\
\hline 34 & 276.56 & 53.14 & 0.02 & 0.64 & 0.30 & 349.0 \\
\hline 35 & 258.15 & 43.23 & 0.04 & 0.27 & 0.30 & 310.8 \\
\hline 36 & 238.41 & 43.63 & 0.00 & 0.93 & 0.20 & 294.4 \\
\hline
\end{tabular}

ECEC: Effective cation exchange capacity 
Continuation appendix 3.2 (soil heterogeneity)

\begin{tabular}{|c|c|c|c|c|c|c|c|c|c|c|c|c|}
\hline ID & $\mathrm{CV} \mathrm{pH}$ & CV BD & CV C & CV N & CV P & $\mathrm{CV} \mathrm{Na}$ & CV K & $\mathrm{CV} \mathrm{Ca}$ & CV Mg & CV Fe & CV Mn & CV Al \\
\hline 1 & 7.5 & 10.3 & 27.4 & 22.5 & 24.5 & 24.1 & 33.6 & 21.6 & 43.7 & 96.2 & 48.2 & 300 \\
\hline 2 & 12.0 & 8.5 & 30.0 & 28.8 & 45.9 & 39.8 & 27.1 & 34.4 & 36.1 & 79.8 & 86.4 & 163 \\
\hline 3 & 5.8 & 10.4 & 35.7 & 28.8 & 19.2 & 33.6 & 34.5 & 28.9 & 30.5 & 125.7 & 19.7 & 114 \\
\hline 4 & 11.0 & 7.5 & 25.2 & 26.6 & 15.0 & 24.4 & 25.6 & 15.0 & 17.5 & 75.4 & 67.4 & 234 \\
\hline 5 & 11.0 & 5.6 & 15.2 & 13.6 & 10.9 & 23.0 & 71.9 & 13.5 & 17.0 & 120.7 & 37.8 & 0 \\
\hline 6 & 5.6 & 11.8 & 27.1 & 25.8 & 13.1 & 28.2 & 11.1 & 12.3 & 12.1 & 58.4 & 30.8 & 300 \\
\hline 7 & 3.5 & 12.3 & 27.9 & 26.6 & 11.2 & 30.4 & 17.2 & 20.9 & 22.4 & 0.0 & 30.9 & 0 \\
\hline 8 & 7.4 & 14.9 & 31.2 & 26.2 & 58.8 & 64.2 & 25.3 & 30.8 & 27.1 & 199.0 & 61.0 & 300 \\
\hline 9 & 10.8 & 14.7 & 51.9 & 50.5 & 28.2 & 26.9 & 37.9 & 21.7 & 29.6 & 299.2 & 53.2 & 221 \\
\hline 10 & 17.6 & 10.2 & 25.6 & 24.1 & 42.7 & 24.8 & 21.1 & 16.9 & 29.6 & 75.4 & 72.8 & 173 \\
\hline 11 & 8.7 & 5.3 & 43.0 & 30.0 & 23.7 & 46.2 & 60.2 & 37.0 & 13.7 & 89.8 & 64.4 & 0 \\
\hline 12 & 3.4 & 8.6 & 22.3 & 21.1 & 12.3 & 21.4 & 16.4 & 18.1 & 23.0 & 123.3 & 39.6 & 95 \\
\hline 13 & 4.3 & 8.0 & 23.6 & 21.8 & 28.4 & 32.2 & 20.9 & 10.5 & 16.9 & 150.1 & 35.1 & 0 \\
\hline 14 & 7.5 & 7.0 & 18.1 & 14.5 & 11.7 & 55.9 & 19.3 & 18.5 & 28.6 & 151.4 & 20.7 & 0 \\
\hline 15 & 6.5 & 6.8 & 14.3 & 15.0 & 24.4 & 55.7 & 47.5 & 20.3 & 21.0 & 200.1 & 63.6 & 300 \\
\hline 16 & 8.8 & 9.6 & 30.5 & 33.1 & 19.9 & 49.9 & 44.8 & 25.6 & 26.5 & 121.0 & 69.3 & 32 \\
\hline 17 & 1.8 & 8.8 & 17.7 & 16.8 & 31.1 & 102.1 & 53.5 & 46.2 & 27.2 & 134.4 & 85.6 & 300 \\
\hline 18 & 5.8 & 7.0 & 14.1 & 13.8 & 9.6 & 9.9 & 43.9 & 21.8 & 18.7 & 0.0 & 34.3 & 0 \\
\hline 19 & 3.7 & 10.1 & 16.9 & 15.0 & 14.4 & 49.0 & 40.0 & 12.3 & 19.0 & 0.0 & 28.0 & 0 \\
\hline 20 & 3.6 & 8.2 & 14.2 & 9.8 & 23.6 & 80.4 & 26.5 & 10.4 & 14.7 & 0.0 & 35.5 & 0 \\
\hline 21 & 4.2 & 14.8 & 40.9 & 36.7 & 27.4 & 72.6 & 39.5 & 30.7 & 33.2 & 120.7 & 24.2 & 0 \\
\hline 22 & 4.8 & 11.1 & 23.9 & 18.4 & 17.9 & 37.6 & 29.3 & 46.4 & 36.2 & 301.6 & 50.9 & 300 \\
\hline 23 & 5.6 & 7.1 & 32.7 & 29.7 & 30.8 & 34.7 & 42.1 & 5.6 & 10.3 & 0.0 & 55.0 & 300 \\
\hline 24 & 4.7 & 9.2 & 38.7 & 35.8 & 9.7 & 20.4 & 46.0 & 16.2 & 25.9 & 303.7 & 39.0 & 300 \\
\hline 25 & 5.8 & 5.5 & 20.4 & 14.6 & 16.1 & 38.5 & 34.7 & 18.4 & 34.8 & 81.2 & 99.2 & 300 \\
\hline 26 & 5.1 & 12.1 & 21.9 & 19.1 & 21.7 & 42.8 & 28.8 & 16.9 & 18.7 & 155.6 & 51.3 & 152 \\
\hline 27 & 5.9 & 5.5 & 29.8 & 26.5 & 46.0 & 63.1 & 44.5 & 18.8 & 22.4 & 80.9 & 36.7 & 300 \\
\hline 28 & 6.4 & 12.0 & 40.5 & 34.2 & 15.3 & 46.2 & 34.0 & 37.0 & 12.0 & 205.2 & 46.3 & 38 \\
\hline 29 & 4.9 & 7.0 & 28.4 & 25.4 & 9.4 & 15.6 & 23.5 & 2.9 & 5.1 & 62.8 & 55.8 & 198 \\
\hline 30 & 3.5 & 9.2 & 15.7 & 15.0 & 11.0 & 27.8 & 19.1 & 22.5 & 33.0 & 0.0 & 76.5 & 0 \\
\hline 31 & 6.4 & 6.5 & 20.4 & 14.1 & 16.6 & 42.2 & 36.9 & 26.3 & 31.9 & 0.0 & 46.2 & 0 \\
\hline 32 & 5.0 & 5.0 & 18.6 & 15.7 & 29.0 & 68.8 & 45.4 & 13.5 & 26.9 & 0.0 & 51.1 & 198 \\
\hline 33 & 2.9 & 13.1 & 26.7 & 25.3 & 14.6 & 35.6 & 29.8 & 30.0 & 43.2 & 199.0 & 34.0 & 164 \\
\hline 34 & 7.6 & 6.3 & 18.9 & 14.1 & 19.4 & 44.0 & 38.4 & 7.6 & 11.7 & 196.9 & 23.5 & 150 \\
\hline 35 & 4.8 & 8.3 & 46.5 & 42.3 & 32.7 & 65.7 & 24.3 & 30.1 & 20.5 & 203.8 & 63.3 & 150 \\
\hline 36 & 7.3 & 5.2 & 29.9 & 24.6 & 14.2 & 35.2 & 37.8 & 22.8 & 25.0 & 0.0 & 46.3 & 198 \\
\hline
\end{tabular}




\section{Appendix 4.1: Inputs variables to LAPSUS MODEL}

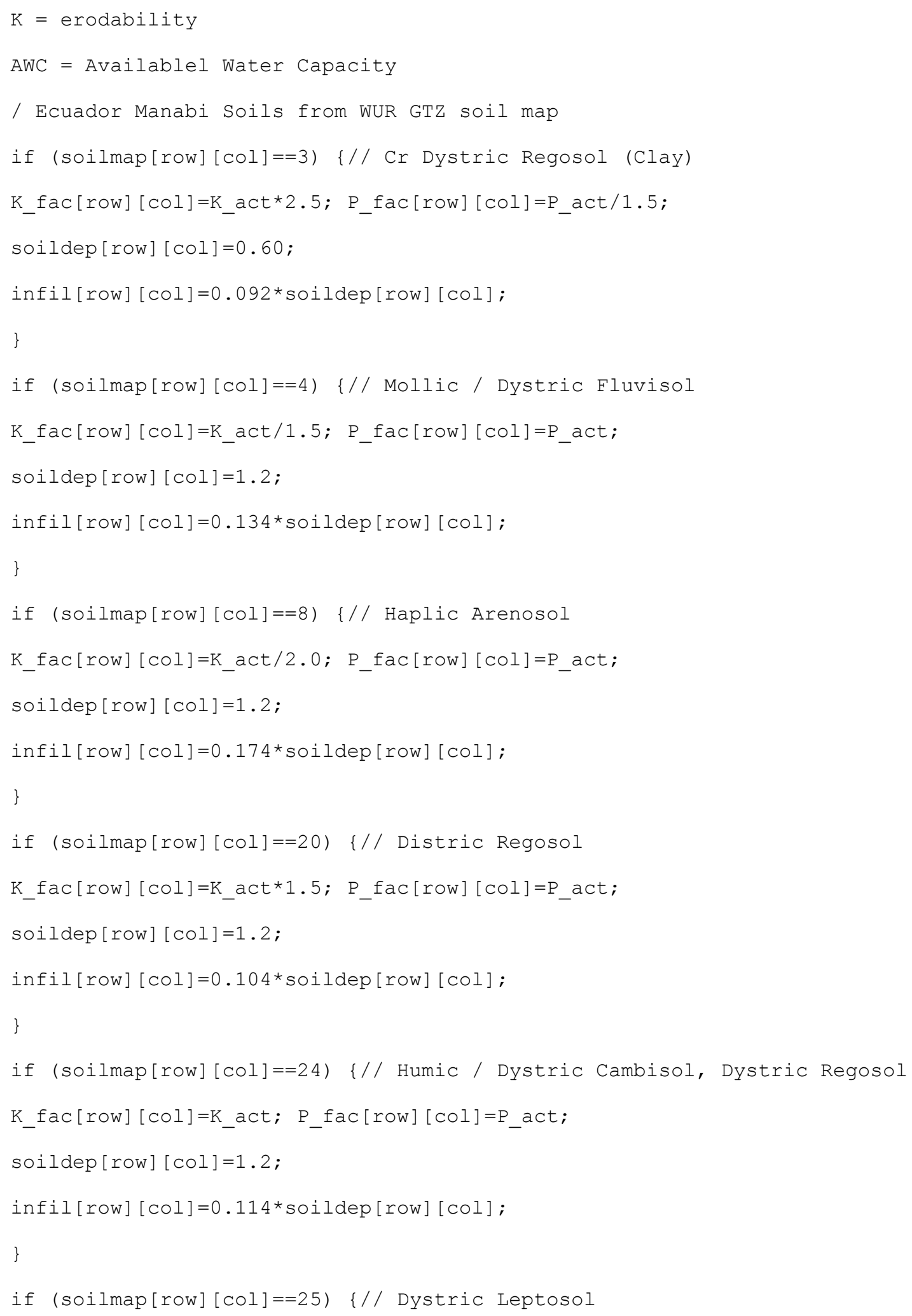




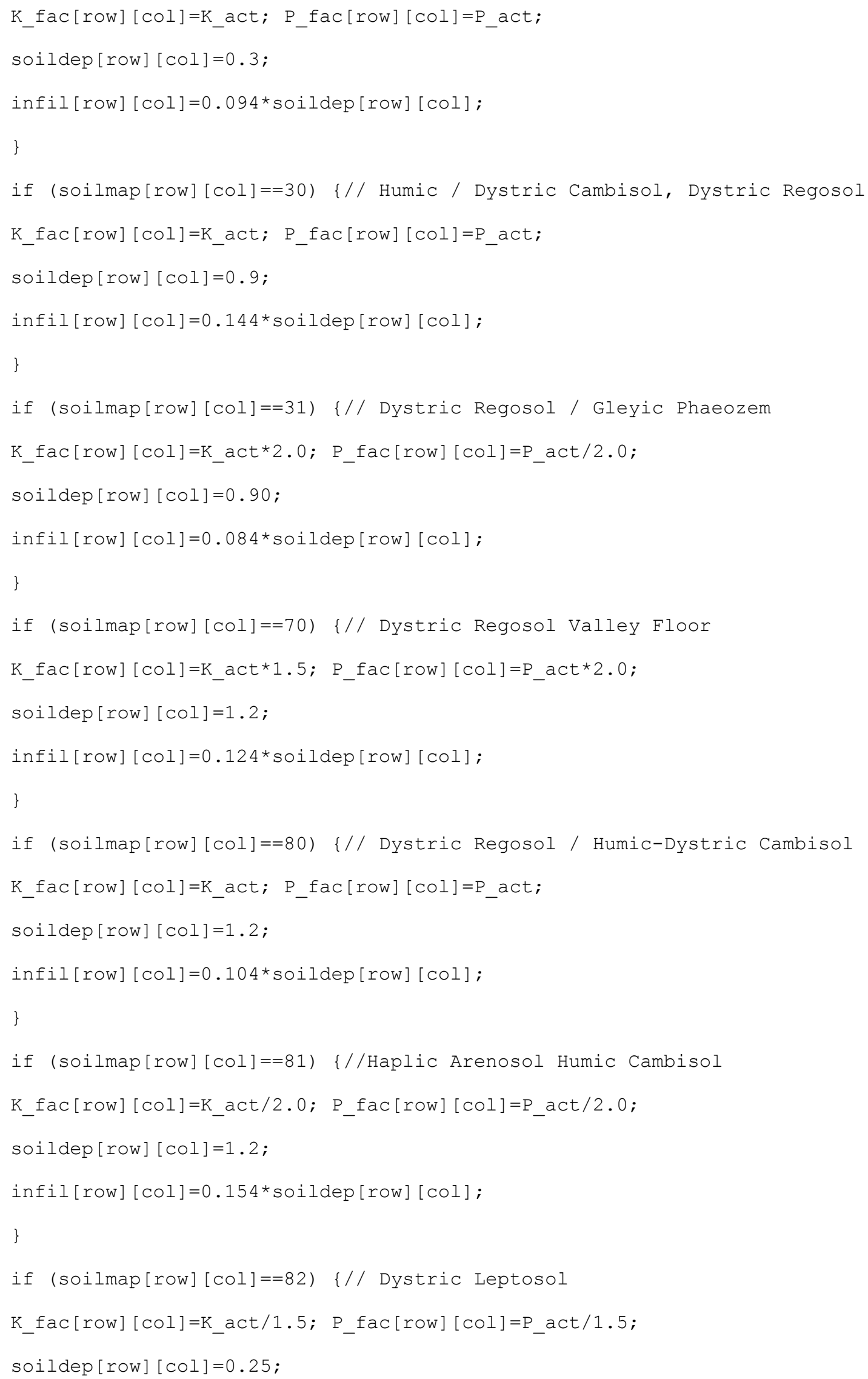




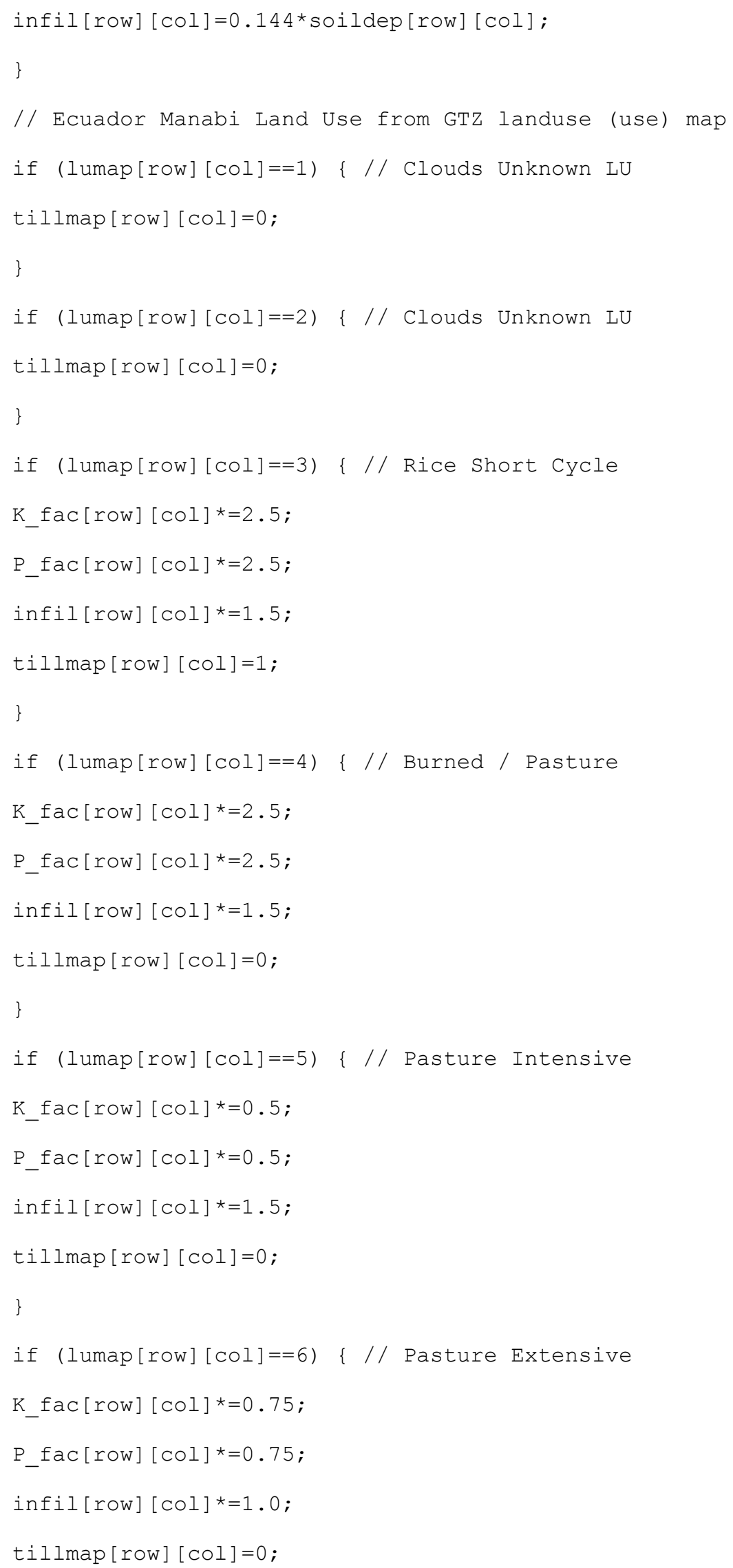




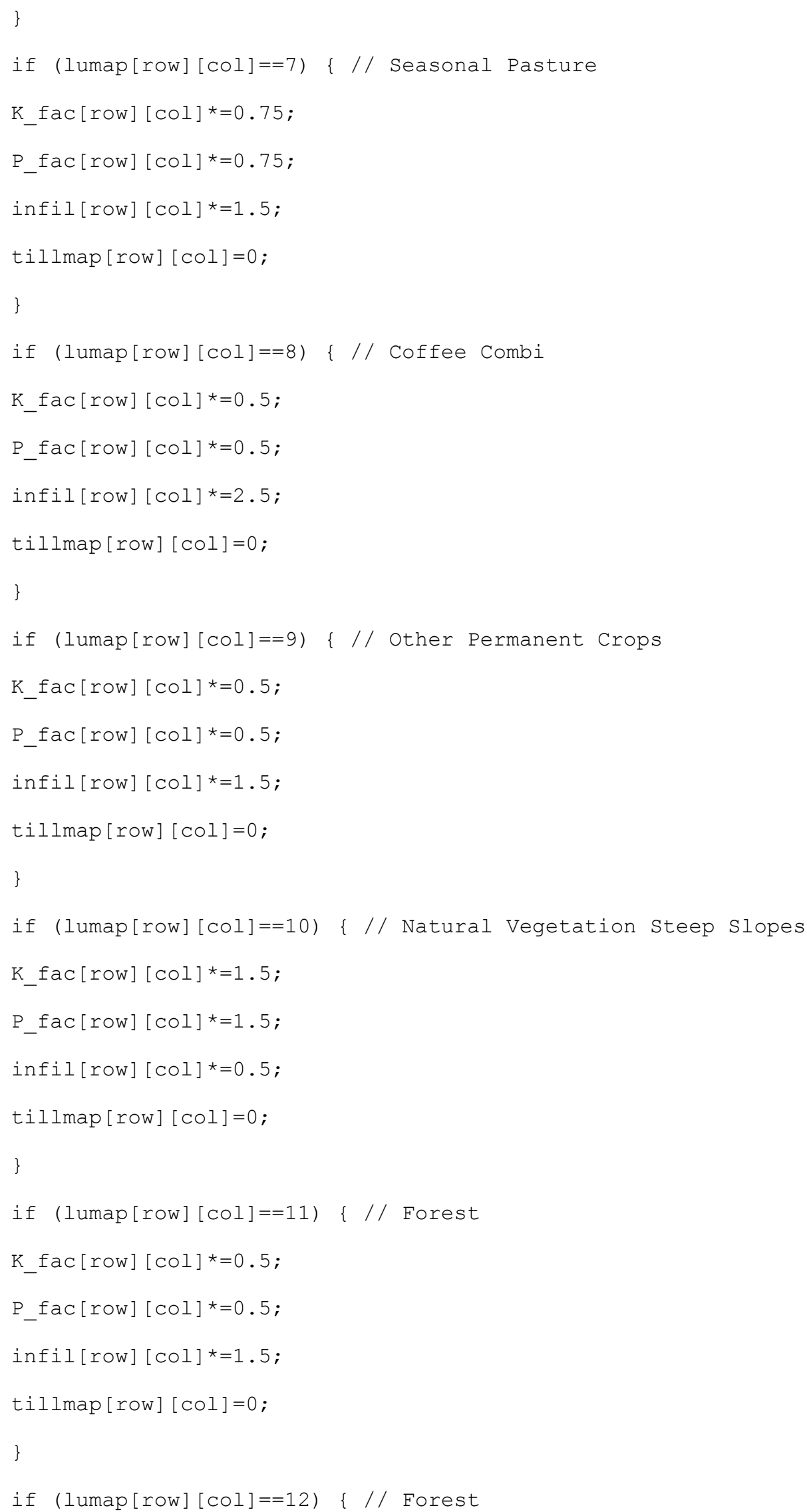




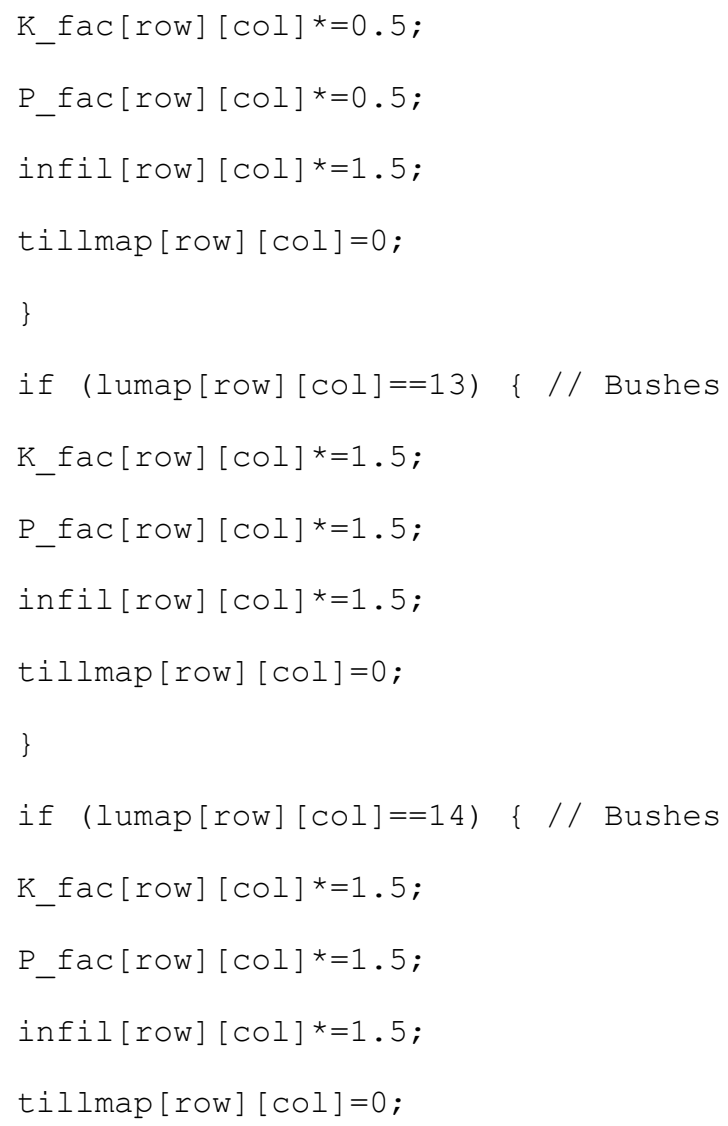




\section{Curriculum vitae}

$\begin{array}{ll}\begin{array}{l}\text { Name } \\ \text { Day of birth }\end{array} & \begin{array}{l}\text { Ruth Magdalena López Ulloa } \\ \text { Place of birth }\end{array} \\ \text { Family status } 31^{\text {th }}, 1958 \\ \text { Address } & \text { Ambato, Ecuador } \\ & \text { Married } \\ \text { Calle J, Casa 7, Conjunto los Olivos, Pomasqui-Quito- } \\ \text { Phone } & \text { Ecuador } \\ \text { Mobile } & 59322354113 \\ \text { E-mail } & 084024874\end{array}$

\section{Education}

Since $02 / 2003$

Drafting of Doctoral Thesis, submitted in May 2006 to

Göttingen University- Germany

09/1998-03/2000

Master Science in Soil and Water, Wageningen

University. Wageningen-The Netherlands

01/1997-05/1985

Chemical Engineer, Central University, Quito-

Ecuador

10/1970- 08/1976

Secondary education at the Inmaculada, High School.

Quito-Ecuador

\section{Work experience}

Since $02 / 2003$

Soil Researcher at the Bio-Sys Project, University of

Göttingen, Institute of Soil Sciences and Forest

Nutrition. Financed through the German Federal

07/1996- 01/2003

Ministry of Education and Research

Agronomic Researcher, National Agronomic Research

Institute. (INIAP Instituto Nacional de Investigaciones Agropecuarias). Soil and Water Department. Santa Catalina Experimental Station, Quito-Ecuador

$08 / 2000-11 / 2001$

Soil Expert at the $\mathrm{CO} 2$ Project- Forest Carbon Sequestration, Financed by, German Society for Technical Cooperation (GTZ)

Responsible of Environmental and Soil Laboratory. 
Collaborator for developing new agronomic and ecological research projects. "Atomic Energy Ecuadorian Commission". Agronomic Application Department, Quito-Ecuador

\section{Academic Presentation and Publications}

2005

2005

2004

2004

2003
López-Ulloa, M., E. Veldkamp, G.H.J. de Koning.

Soil carbon stabilization in converted tropical pastures and forests depends on soil type. Soil Sci. Soc. Am. J.

Free de Koning, Roland Olschewski, Edzo Veldkamp, Pablo Benítez, Pablo Laclau, Magdalena López-Ulloa, Tomás Schlichter, Mercedes de Urquiza. The Ecological and Economic Potential of Carbon Sequestration in Forests; Examples from South America. AMBIO

López-Ulloa, M., E. Veldkamp, G.H.J. de Koning. Estabilización del recientemente incorporado carbono del suelo dependiendo del tipo de suelo: evidencias en la conversión de pastos y bosques en el Ecuador. Loja. CD del VII Congreso de la Ciencia del suelo

Guerra-Mendoza, I., M. López-Ulloa. Estudio de la mineralización neta "in situ" del nitrógeno en sistemas agroforestales de café (coffea arabiga), cultivos de arroz (oriza sativa) y pastos en dos tipos de suelo del sur de Manabí. Loja. CD del VII Congreso de la Ciencia del suelo

de Koning G.H.J., E. Veldkamp, M. López-Ulloa. Quantification of carbon sequestration in soils following pasture to forest conversion in northwestern Ecuador. Global Biogeochemical 
Cycles

2002

López, M., G.H.J. de Koning, H. Paredes, P. Benitez. Estimación de carbono en biomasa de bosques secundarios y plantaciones forestales en el noroccidente de Ecuador. Report TWF-31s, Tropical Ecology Support Program (TOEB) of the German Technical Cooperation (GTZ). Eschborn, Germany.http://www.gtz.de/toeb/

Benitez, P., R. Olschewski, G.H.J. de Koning, M. López. Analisis de costo-beneficio de usos del suelo y fijación de carbono en sistemas forestales de Ecuador Noroccidental. Report TWF-30s, Tropical Ecology Support Program (TOEB) of the German Technical Cooperation (GTZ). Eschborn, Germany. http://www.gtz.de/toeb/

López, M., J. Stoorvogel. "Spatial Patron in soil fertility within of San Gabriel area, Ecuador". Memories of VI Congress of Soil Science Ecuador

$03 / 2005$

$1^{\text {st }}$ Workshop. Bioteam Projects- Federal Ministry of Education and Research. Theme "Importance of soil type and soil properties for plant diversity". Bonn-Germany

$11 / 2004$

International Biodiversity Seminar. Poster "Soil diversity and quality in different land use systems in coastal Ecuador”. Berlin-Germany 